UNIVERSIDADE DE SÃO PAULO

FACULDADE DE ECONOMIA, ADMINISTRAÇÃO E CONTABILIDADE DEPARTAMENTO DE CONTABILIDADE E ATUÁRIA

\title{
O PAPEL DO AUDITOR CONTÁBIL NA AUDITORIA DE SISTEMAS DE GARANTIA DA QUALIDADE
}

BENEDICTO DAVID FILHO

Orientador: Prof. Dr. Antonio Loureiro Gil

São Paulo

1995 


\title{
UNIVERSIDADE DE SÃO PAULO
}

\section{FACULDADE DE ECONOMIA, ADMINISTRAÇÃO E CONTABILIDADE}

\author{
DEPARTAMENTO DE CONTABILIDADE E ATUÁRIA
}

\author{
O PAPEL DO AUDITOR CONTÁBIL \\ NA AUDITORIA DE SISTEMAS DE \\ GARANTIA DA QUALIDADE
}

\section{BENEDICTO DAVID FILHO}

Dissertação apresentada ao
Departamento de Contabilidade e
Atuária da Faculdade de Economia,
Administração e Contabilidade da
Universidade de São Paulo, para
obtenção do Título de Mestre em
Contabilidade.

Orientador: Prof. Dr. Antonio Loureiro Gil

\section{São Paulo}


UNIVERSIDADE DE SÃO PAULO

Reitor: Prof. Dr. Flávio Fava de Moraes

FACULDADE DE ECONOMIA, ADMINISTRAÇÃO E CONTABILIDADE Diretor: Prof. Dr. Denisard Cnéio de Oliveira Alves

DEPARTAMENTO DE CONTABILIDADE E ATUÁRIA

Chefe: Prof. Dr. Masayuki Nakagawa 
Aos meus pais Benedicto (in memoriam) e Esmeralda, por terem me ensinado o caminho do bem e do respeito ao ser humano; à minha filha Mariana, a quem espero poder deixar este legado, e à minha esposa Leda Maria, por sua tolerância e compreensão com as constantes e prolongadas ausências e pelo apoio nas horas difíceis. 


\section{AGRADECIMENTOS}

A realização deste trabalho não teria sido possível sem a ajuda inestimável de alguns seres humanos que, na grandeza de suas bondades, não mediram esforços/sacrifícios para que este projeto não sofresse solução de continuidade.

Ao amigo Antonio de Loureiro Gil, por sua orientação e ensinamentos. Sua sabedoria e profundo conhecimento das questões sobre a qualidade foram decisivos na definição e na abordagem do tema.

Agradeço, através do amigo José Roberto, a todos os colaboradores da CPC, Companhia Petroquímica de Camaçari - Unidade de São Paulo, que forneceram subsídios valiosos, direcionando algumas das conclusões alcançadas.

Agradeço, através do Auditor Matheus Batista de Araujo, à empresa Certificadora ABS Group Services do Brasil Ltda., por permitir o acompanhamento de uma auditoria de controle relatada como estudo de caso no item 3.7. deste trabalho.

A todos os professores da Faculdade de Economia, Administração e Contabilidade da Universidade de São Paulo e, em especial, aos professores do Departamento de Contabilidade e Atuária, pelo privilégio do convívio e pelos ensinamentos transmitidos.

Aos colegas de mestrado que dividiram comigo as dificuldades de pesquisar, elaborar e apresentar trabalhos para obtenção dos créditos nas diversas disciplinas. Aprendi muito com vocês. 
A todos os funcionários da FEAC, pelo profissionalismo, colaboração e humildade. Vocês enriqueceram meu lado humano.

Agradeço, através da amiga IARA PASIAN, a todos os amigos da DELOITTE TOUCHE TOHMATSU, por sua compreensão, paciência e troca de idéias, que contribuíram muito para minha formação profissional e como ser humano.

Aos amigos ISABEL, pela revisão cuidadosa do texto, e RICARDO, pela editoração do trabalho.

Agradeço a Deus por ter me dado forças e lucidez. 


\section{APRESENTAÇÃO}

A integração dos mercados econômicos decorrente do processo de globalização da economia trouxe à discussão as questões da qualidade relacionadas a necessidade de padronização de produtos, serviços e processos. Neste sentido, os padrões internacionais, série ISO 9.000, emitidos pela International Organization for Standardization, com ênfase maior a partir da década de noventa, passaram a ser adotados por várias empresas como forma de comprovada e sistematicamente garantir a qualidade de seus processos, produtos e serviços.

As empresas que implementaram sistemas de gestão e garantia da qualidade acabaram por modificar seus processos como um todo, particularmente, aqueles diretamente relacionados as questões da qualidade e determinaram alterações significativas nos sistemas de controle interno.

A obrigatoriedade de realização de auditorias da qualidade, com o objetivo de averiguar se as atividades da qualidade estão em conformidade com a forma planejada e determinar a eficácia do sistema de garantia da qualidade, forneceu o ponto de partida para a elaboração desta dissertação, que tem como objetivo discutir o papel do auditor contábil (independente) na auditoria da qualidade e contribuir, através da identificação de alguns caminhos possíveis, para uma efetiva participação desses profissionais na auditoria de sistemas de garantia da qualidade.

O papel que discutimos, e pelo qual temos firme convicção, o auditor contábil pode e deve dar sua contribuição profissional às questões da qualidade, está relacionado ao valor agregado da auditoria contábil, num ambiente empresarial, 
onde as funções do auditor contábil vêm se expandindo, tendo como alvo a gestão empresarial.

A presente dissertação está estruturada em cinco capítulos a saber:

- O Capítulo 1 apresenta os objetivos do trabalho, os antecedentes, as questões problema, a relevância da pesquisa e a metodologia aplicada;

- O Capítulo 2 discute o conceito de qualidade, apresenta as normas de gestão e garantia da qualidade e detalha o sistema de gestão da qualidade e o sistema de garantia da qualidade;

- O Capítulo 3 apresenta as normas de auditoria da qualidade, discute o que é auditoria da qualidade, os objetivos, a abrangência e as responsabilidades e apresenta uma abordagem de auditoria de sistemas de garantia da qualidade;

- O Capítulo 4 apresenta as normas de auditoria contábil, discute o que é auditoria contábil, os objetivos, a abrangência e as responsabilidades e apresenta uma abordagem de auditoria contábil sobre o sistema de controle interno;

- O Capítulo 5 discute o papel do auditor contábil na auditoria de sistemas de garantia da qualidade definindo as responsabilidades e o perfil adequado desse profissional, correlacionando o ciclo da qualidade e o ciclo contábil e identificando alguns caminhos possíveis onde esse papel pode ser desempenhado; e

- As conclusões e a bibliografia consultada completam o trabalho. 


\section{ABSTRACT}

The integration of economic markets, resulting from the economy globalization process, brings to discussion quality issues concerning the need to standardize products, services and processes. In this direction, the international standards, ISO 9.000 series, issued by the International Organization for Standardization, mainly from the nineties on, have been adopted by several companies in order to consistently and systematically assure the quality of their processes, products and services.

The Companies which implemented a quality assurance and management system had to modify their processes as a whole, particularly those directly related to quality issues, which determined significant alterations in the internal control systems.

The need to perform quality audits in order to verify that quality-related activities are in compliance with the planned way and determine the effectiveness of the quality assurance system provided the starting point for this thesis, which aims at discussing the role of the (independent) accounting auditor in the quality audit and contribute, by identifying some possible ways, to an effective participation of these professionals in the audit of the quality assurance system.

The role dicussed here, which, we do believe, can and must give a professional contribution to quality matters, is related to the accounting audit added-value, in a business environment, where accounting auditor have expanded their line of work, having as a goal the business management. 
This thesis is divided into five chapters, as follows:

- Chapter 1 introduces the objectives of the work, the background, the problemissues, the relevance of the research and the methodology applied;

- Chapter 2 discusses the quality concept, introduces the rules for managing and assuring quality and details the quality assurance and management system;

- Chapter 3 covers the rules for auditing quality, discusses the concept of quality audit, its objectives, scope and responsibilities, and introduces an approach of audit for quality assurance systems;

- Chapter 4 introduces the accounting audit rules, discusses the concept of accounting audit, its objectives, scope, responsibilities and focuses an approach of accounting audit on the internal control system;

- Chapter 5 discusses the role of the accounting auditor in auditing quality assurance systems, by defining both his responsibilities and professional profile. It also relates the quality cycle to the accounting cycle and identifies some possible ways where this role can be performed; and

- The conclusion and bibliography complete the work. 


\section{SUMÁRIO}

Item

Páginas

\section{CAPÍTULO 1}

\section{INTRODUÇÃO}

1.1. Objetivo do trabalho 1

1.2. Antecedentes do problema 3

1.3. O problema 5

1.4 Relevância $\quad 7$

$\begin{array}{lll}1.5 & \text { Metodologia da pesquisa } & 7\end{array}$

\section{CAPÍTULO 2}

\section{O SISTEMA DE GESTÃO E GARANTIA DA QUALIDADE}

2.1

O que é QUALIDADE ?

2.2

Normas de gestão e garantia da qualidade

2.2.1

Sistema de gestão da qualidade

2.2.1.1. Responsabilidade da administração

2.2.1.2.1.1 Marketing e pesquisa de mercado

2.2.1.2.1.2 Engenharia de projeto/especificação e desenvolvimento de produto

2.2.1.2.1.3 Aquisição

2.2.1.2.1.4. Planejamento e desenvolvimento de projeto

2.2.1.2.1.5. Produção

2.2.1.2.1.6. Inspeção, ensaio e exame

2.2.1.2.1.7. Embalagem e armazenamento 
2.2.1.2.1.8. Vendas e distribuição 25

2.2.1.2.1.9. Instalação e operação 25

2.2.1.2.1.10. Assistência técnica e manutenção 26

2.2.1.2.1.11. Disposição após uso 26

$\begin{array}{lll}2.2 .1 .2 .2 & \text { A estrutura } & 26\end{array}$

$\begin{array}{lll}\text { 2.2.1.2.3 A documentação } & 27\end{array}$

$\begin{array}{lll}2.2 .1 .2 .4 & \text { A auditoria } & 28\end{array}$

2.2.1.2.5 A análise crítica 28

2.2.1.3 Economia - Custos da qualidade 28

2.2.1.4 Não-conformidade 29

2.2.1.5 Ação corretiva 29

2.2.1.6 Pessoal 30

2.2.1.7 Segurança e responsabildade cível pelo fato do produto 31

2.2.1.8 Uso de métodos estatísticos 31

2.2.1.9 Sistema de gestão da qualidade: algumas considerações 32

2.2.2 Sistema de Garantia da Qualidade 32

2.2.2.1. Responsabilidade da administração 34

2.2.2.2 Sistema da qualidade 35

2.2.2.3 Análise crítica do contrato 37

2.2.2.4 Controle do projeto 37

2.2.2.5 Controle de documentos 38

$\begin{array}{lll}2.2 .2 .6 & \text { Aquisição } & 38\end{array}$

2.2.2.7 Produto fornecido pelo comprador 38

2.2.2.8 Identificação e rastreabilidade de produto 39

2.2.2.9 Controle de processo 39

2.2.2.10 Inspeção e ensaios 39

2.2.2.11 Equipamentos de inspeção, medição e ensaios 40

2.2.2.12 Situação da inspeção e ensaio 40

2.2.2.13 Controle de produtos não conformes 40

2.2.2.14 Ação corretiva 41

2.2.2.15 Manuseio, armazenamento, embalagem e expedição 41

$\begin{array}{lll}\text { 2.2.2.16 Registros da qualidade } & 41\end{array}$

2.2.2.17 Auditorias internas da qualidade 41

2.2.2.18 Treinamento 42

2.2.2.19 Assistência técnica 42

2.2.2.20 Técnicas estatísticas 42 
2.2.2.21 Sistema de garantia da qualidade: algumas considerações

\section{CAPÍTULO 3}

\section{AUDITORIA DE SISTEMAS DE GARANTIA DA QUALIDADE}

3.1

As normas de auditoria da qualidade

3.1.1.

Diretrizes para auditoria de sistemas da qualidade - Parte 1

Auditoria

3.1.2. Diretrizes para auditoria de sistemas da qualidade - Parte 2 Critérios para qualificação de auditores de sistema da qualidade

3.1.3. Diretrizes para auditoria de sistemas da qualidade - Parte 3 Gestão de programas de auditoria

3.2.

O que é auditoria da qualidade?

Objetivos da auditoria da qualidade

3.4 .

A abrangência da auditoria da qualidade

As responsabilidades no processo de auditoria de sistemas de garantia da qualidade

3.5.1.

As responsabilidades do auditado

As responsabilidades do auditor

A abordagem de auditoria de sistemas de garantia da qualidade

Planejamento da auditoria

Avaliar os objetivos da auditoria

Estabelecer condições para execução da auditoria

Atividades durante a execução da auditoria 
$\begin{array}{lll}\text { 3.6.2.2 } & \text { Atividades pós-auditoria } & 72\end{array}$

$\begin{array}{lll}\text { 3.6.2.2.1 } & \text { Preparação do relatório de auditoria } & 73\end{array}$

$\begin{array}{lll}\text { 3.6.2.2.2 } & \text { Revisão de qualidade } & 73\end{array}$

3.6.2.2.3 Acompanhamento "Follow-up" de ações corretivas 73

$\begin{array}{lll}3.6 .3 & \text { Atividades de controle } & 74\end{array}$

$\begin{array}{lll}\text { 3.6.3.1 } & \text { Periodicidade das auditorias } & 74\end{array}$

$\begin{array}{lll}\text { 3.6.3.2 } & 75\end{array}$

3.6.3.3. Rodízio de auditores 76

$\begin{array}{lll}\text { 3.6.3.4 } & \text { Qualidade das auditorias } & 77\end{array}$

$\begin{array}{lll}\text { 3.6.3.5 } & \text { Qualificação dos auditores } & 77\end{array}$

3.6.3.6. Considerações finais 78

3.7. Estudo de caso:

Acompanhamento de auditoria de controle do sistema de garantia da qualidade

\section{CAPÍTULO 4}

\section{AUDITORIA CONTÁBIL}

4.1 Normas de auditoria $\quad 84$

$4.2 \quad$ Oue é auditoria contábil ? 85

$\begin{array}{lll}4.3 & \text { O objetivo da auditoria contábil } & 87\end{array}$

$4.4 \quad$ A abrangência da auditoria contábil 87

$4.5 \quad$ As responsabilidades no processo de auditoria contábil $\quad 89$

4.6 A abordagem da auditoria contábil sobre o sistema de controle interno 90

4.6.1. A importância do controle interno - Antecedentes 91

4.6.2. O conceito de controle interno 98

4.6.3. Controle interno e o sistema de gestão e garantia da qualidade 107

4.6.4. O ciclo do controle interno contábil 108

4.6.4.1 Ciclo de vendas, faturamento e despacho do produto, contas a receber e recebimentos 108

$\begin{array}{lll}\text { 4.6.4.2 } & \text { Ciclo de estoque e custo das vendas } & 109\end{array}$

4.6.4.3 Ciclo de compras, recebimento de mercadorias, contas a pagar e pagamentos 110

$\begin{array}{lll}\text { 4.6.5. } & \text { Pontos de controle interno contábil } & 110\end{array}$ 


\section{CAPÍTULO 5}

\section{O PAPEL DO AUDITOR CONTÁBIL NA AUDITORIA DE SISTEMAS DE GARANTIA DA QUALIDADE}

5.1. As responsabilidades do auditor contábil na auditoria de sistemas de garantia da qualidade 121

$\begin{array}{lll}5.2 & \text { O perfil do auditor contábil adequado à auditoria da qualidade } & 122\end{array}$

5.2.1 O perfil do candidato a auditor da qualidade definido na norma ISO 10.011-2

5.2.2 O perfil do auditor da qualidade estabelecido pelos Orgãos Certificadores

5.2 .3

O perfil do auditor contábil

5.2 .4

O perfil do auditor contábil voltado à auditoria da qualidade

5.2 .5 Algumas considerações O papel do auditor contábil na auditoria de sistemas de garantia da qualidade - Caminhos possíveis 


\section{ÍNDICE DAS FIGURAS}

5.1

Matriz de correlação entre o ciclo da qualidade e os pontos de controle interno contábil

Momentos da auditoria contábil e o ciclo administrativo da qualidade 


\section{1 Objetivo do trabalho}

O objetivo do presente trabalho é discutir o papel do auditor contábil (independente) na auditoria da qualidade e contribuir, através da identificação de alguns caminhos possíveis, para uma efetiva participação desses profissionais na auditoria de sistemas de garantia da qualidade.

O termo 'auditor contábil' será utilizado neste trabalho para identificar o profissional, independente, da área contábil especializado em auditoria das demonstrações contábeis.

Auditoria da qualidade é uma atividade formal e documentada para verificação do processo de gestão e garantia da qualidade.

O presente estudo parte do princípio de que o papel do auditor contábil não está diretamente relacionado ao aspecto da certificação, que envolve, entre outras coisas, os organismos especializados em qualidade, mas sim ao valor agregado da auditoria contábil num ambiente empresarial. Daí termos a firme convicção de que o auditor contábil pode e deve dar sua contribuição profissional às questões da qualidade. 
O valor agregado da auditoria contábil tem sido crescente ao longo das últimas décadas, principalmente pelo fato de o auditor contábil ter se especializado em assuntos empresariais. Portanto, à medida que o meio empresarial vem dedicando parcelas cada vez mais significativas de seu dia-a-dia às questões da qualidade, é de se esperar que o auditor contábil também passe a voltar sua atenção para o assunto.

$\mathrm{Na}$ busca dos caminhos possíveis para a efetiva participação do auditor contábil na auditoria de sistemas de garantia da qualidade, constata-se que o sistema de garantia da qualidade é parte integrante do sistema de controle interno de uma entidade, permitindo não só estabelecer o elo de ligação entre o auditor contábil e o sistema de garantia da qualidade, mas também desenvolver uma abordagem mais efetiva sobre o papel reservado ao auditor contábil nesse contexto.

Considerando que o sistema de controle interno é parte determinante no processo de auditoria contábil e, portanto, tem sido motivo de preocupação para estes profissionais nos últimos tempos, e que o valor agregado da auditoria contábil tem obrigado estes profissionais a ampliarem seus conhecimentos das áreas que envolvem a gestão empresarial, dois momentos de auditoria contábil aplicados no ciclo administrativo da qualidade são identificados como caminhos possíveis:

O primeiro guarda relação com a defìnição de um objetivo de serviço ao cliente, quando o auditor contábil procura de forma sistemática agregar valor ao seu trabalho, podendo eleger, por exemplo, um subsistema do sistema de garantia da qualidade como objetivo de serviço a ser desenvolvido paralelamente à auditoria das demonstrações contábeis. 
O segundo está relacionado ao estudo e avaliação do sistema de controle interno, quando o auditor contábil busca adquirir um entendimento suficiente sobre o sistema de controle interno a fim de estabelecer um grau de confiança e determinar a extensão e a oportunidade para realização dos outros procedimentos de auditoria.

Além da identificação de alguns caminhos possíveis para a participação do auditor contábil na auditoria de sistemas de garantia da qualidade, destacam-se como contribuição própria deste trabalho a definição de uma matriz de correlação entre o ciclo da qualidade e os pontos de controle interno contábil, bem como a identificação do perfil do auditor contábil voltado às questões da qualidade.

\section{$1.2 \quad$ Antecedentes do problema}

A Organização Internacional para Padronização (ISO - International Organization for Standardization) iniciou seus trabalhos em fevereiro de 1947, com o objetivo de promover o desenvolvimento da padronização e atividades relacionadas em base mundial, facilitar a troca de bens e serviços e desenvolver cooperação na esfera intelectual científica, tecnológica e econômica, apresentando como resultado os Padrões Internacionais (International Standards).

Mais de 8.000 normas já foram publicadas pela ISO, sendo que o presente trabalho incluirá as normas: 8.402, que define os termos básicos e fundamentais relativos à questão da qualidade; a série de normas ISO 9.000 que define as normas de gestão e garantia da qualidade, e o padrão ISO 10.011, que estabelece diretrizes para auditoria de sistemas da qualidade. 
Ao estabelecer diretrizes para a auditoria de sistemas da qualidade (ISO 10.011-1, 10.011-2 e 10.011-3), a Comissão Técnica da Qualidade, o TC 176, uma entre as mais de 300 Comissões Técnicas existentes, num total de mais de 2.600 grupos de trabalho, envolvendo cerca de 20.000 especialistas trabalhando para a ISO em todo o mundo, forneceu os elementos necessários para a elaboração deste trabalho.

Por outro lado, ao longo dos últimos anos, os profissionais da área contábil com especialização em auditoria contábil têm se especializado em assuntos empresariais, tais como: controles de produção, custos, vendas, assessoria tributária e societária, assessoria em processamento eletrônico de dados, treinamento, recursos humanos, avaliações patrimoniais e de empresas, revelando a crescente expansão de suas atividades sempre voltada às necessidades empresariais como um todo. Esta expansão ocorreu sem que o auditor deixasse de se preocupar com o estabelecimento de normas e procedimentos para auditoria das demonstrações contábeis das entidades, objetivo básico de sua existência como profissional da área contábil.

É notório que, principalmente na década de noventa, termos como: 'qualidade', 'programas de qualidade', 'sistema de qualidade', 'sistema de gestão da qualidade', 'auditoria da qualidade' passaram a povoar o ambiente empresarial. Assim, é cada vez maior a freqüência com que os profissionais da auditoria contábil vêm dirigindo sua atenção às questões da qualidade.

Uma das principais preocupações dos auditores contábeisl durante a última década tem sido o sistema de controle interno das entidades. Várias iniciativas em termos de normatização, entendimento comum do conceito e estabelecimento de 
responsabilidades, foram desenvolvidas por esses profissionais, sempre com 0 objetivo de determinar a natureza, a época e a extensão dos demais procedimentos de auditoria que deve executar para formar uma opinião que expresse se as demonstrações contábeis representam adequadamente a situação patrimonial e financeira da entidade, tendo como parâmetro os princípios fundamentais de contabilidade.

O papel da auditoria no sistema de gestão e garantia da qualidade em última análise visa a determinar: a conformidade ou não dos elementos do sistema com os requisitos especificados; a eficácia do sistema de garantia da qualidade implementado no atendimento aos objetivos da qualidade especificados; fornecer ao auditado uma oportunidade de melhorar o sistema; atender aos requisitos regulamentares, e permitir o cadastramento do sistema da qualidade da entidade auditada em um registro.

O relacionamento que se procura estabelecer entre o sistema de controle interno e o sistema de garantia da qualidade visa, num primeiro momento, a alinhar dentro do ambiente empresarial e, de uma visão sistêmica organizacional, à interação destes sistemas, estabelecendo os pontos comuns percorridos por auditores contábeis e auditores do sistema de garantia da qualidade que servirão de base para definição do papel que o auditor contábil pode desempenhar na auditoria desses sistemas.

\section{3. $\quad$ problema}

O papel do auditor contábil na auditoria de sistemas de garantia da qualidade constitui o foco da discussão aqui proposta. Como este profissional poderia 
contribuir para as entidades que já implementaram ou estão para implementar um sistema de garantia da qualidade, mantendo como perspectiva principal e fundamental de seu trabalho a auditoria das demonstrações contábeis?

Dentro desta perspectiva, o trabalho procura discutir questões bastante objetivas, entre as quais destacamos:

- O auditor contábil poderá utilizar a mesma abordagem de auditoria para as entidades que praticam qualidade, isto é, entidades que já implementaram o sistema de gestão e garantia da qualidade, e para aquelas que ainda não implementaram tais sistemas?

- Quais as responsabilidades atribuíveis ao auditor contábil na auditoria de sistemas de garantia da qualidade?

- O perfil do profissional de auditoria contábil seria o mesmo que o dos auditores contábeis tradicionais ou existiriam qualificações adicionais necessárias para o bom desempenho destes profissionais em entidades que praticam qualidade?

- Como se estabelece a correlação entre as atividades desenvolvidas pelo auditor contábil no processo de auditoria das demonstrações contábeis e as atividades desenvolvidas pelo auditor da qualidade no processo de auditoria de sistemas de garantia da qualidade? 
A relevância deste estudo está na sua oportunidade, já que qualidade é o assunto do momento, vis-à-vis a globalização dos mercados e a emergente necessidade de padronização de produtos, serviços e processos; a importância desta pesquisa reside também na busca do relacionamento da auditoria contábil com a auditoria de sistemas de garantia da qualidade, através do sistema de controle interno do qual o sistema de garantia da qualidade, uma vez implementado, torna-se parte integrante. A ênfase recai ainda na perspectiva de estes profissionais utilizarem seus conhecimentos técnicos de auditoria para execução de auditoria de sistemas de garantia da qualidade, de acordo com as normas da ISO 9.000 .

\subsection{Metodologia da pesquisa}

A metodologia utilizada na pesquisa é a bibliográfica descritiva: num primeiro momento se procura um entendimento do ambiente da qualidade (o que é qualidade, o que é um sistema de gestão e garantia da qualidade, como a auditoria se insere neste ambiente e, finalmente, o papel do auditor contábil).

A pesquisa bibliográfica baseia-se em três fontes de informações: a) pronunciamentos da ABTN (Associação Brasileira de Normas Técnicas), que vem referendando no âmbito nacional os padrões internacionais sobre qualidade emitidos pela ISO (International Standard Organization); b) pronunciamentos dos organismos profissionais American Institute of Certified Public Accountants (AICPA), International Federation of Accountants (IFAC), Conselho Federal de Contabilidade (CFC) e Instituto Brasileiro de Contadores (IBRACON); e c) artigos, 
livros, teses e dissertações publicados por diversos profissionais da área de auditoria contábil e auditoria de sistemas de garantia da qualidade, adicionandose a experiência profissional deste pesquisador na área de auditoria contábil. 


\section{CAFICULO 2 \\ O SISLEMA DE GESLIOE \\ GARANEHA DA QUAALIDADE}

Antes de falarmos da Auditoria de Sistema de Garantia da Qualidade, julgamos necessário compreender o contexto em que ela se insere, ou seja, precisamos conhecer, em linhas gerais, o que é o sistema de gestão e garantia da qualidade normatizado pela International Standards Organization (ISO) e o papel da Auditoria neste sistema e, a partir daí, iniciar o estudo do objeto principal deste trabalho, que é o papel do auditor contábil na auditoria de sistemas de garantia da qualidade.

\section{$2.1 \quad$ Q que é QUALIDADE?}

Inúmeros são os conceitos inseridos nas definições de qualidade. Neste trabalho, elencaremos algumas definições de autores, sem a pretensão de esgotar 0 assunto ou firmar novo conceito, com o objetivo de filtrarmos o ponto comum dessas definições e utilizá-lo como base nas discussões subseqüentes.

Ao citar a definição de Walter A. Shewhart (1931), no prefácio do livro Gerência da Qualidade Total, Vicente Falconi Campos ${ }^{1}$ revelou que a preocupação com qualidade, a despeito de o assunto estar sendo amplamente difundido nos anos 90, não é recente. Shewhart, a quem Deming um dia chamou de mestre, assim definiu qualidade: 
A dificuldade em definir qualidade é a de traduzir as necessidades futuras do usuário em características mensuráveis, de forma que o produto possa ser projetado e transformado para oferecer satisfação a um preço que o cliente possa pagar. Isto não é fácil., e assim que se sente razoavelmente bem sucedido nesta tarefa, descobre-se que as necessidades do cliente mudaram, outros concorrentes entraram no mercado, surgiram novos materiais, alguns melhores que os antigos, outros piores, alguns mais baratos, outros mais apreciados.

A ISO 8.402 - Quality - Vocabulary ${ }^{2}$ assim define qualidade:

quality: the totality of features and characteristics of a product or service that bear on its ability to satisfy stated or implied needs.

[qualidade: a totalidade das propriedades e características de um produto ou serviço que the confere a capacidade de satisfazer necessidades explícitas ou implícitas].

Campos $^{3}$ coloca sua definição no contexto de que o objetivo das organizações humanas é atender às necessidades do ser humano e assim,

um produto ou serviço de qualidade é aquele que atende perfeitamente, de forma confiável, de forma acessível, de forma segura e no tempo certo às necessidades dos clientes.

Julio Lobos ${ }^{4}$ define qualidade como uma condição de perfeição ou, então, do exato atendimento das expectativas do cliente. Pode ser atribuída a qualquer coisa ou ação, integrante ou resultante de um processo. A qualidade tem a ver primordialmente com o processo pelo qual os produtos ou serviços são materializados. A qualidade reside no que se faz - aliás, em tudo que se faz - e não apenas no que se tem como conseqüência disso. Neste sentido: 
Qualidade é tudo o que alguém faz ao longo de um Processo para garantir que um Cliente, fora ou dentro da organização, obtenha exatamente aquilo que deseja - em termos de características intrínsecas, custo e atendimento.

Masaaki Imai5 define qualidade do ponto de vista da estratégia do KAIZEN (melhorias contínuas), cuja ênfase recai sobre a qualidade das pessoas e não dos produtos ou serviços, como geralmente se tende a pensar. Somente depois de as pessoas estarem solidamente estruturadas é que se deve pensar nos demais aspectos. Incorpor a qualidade às pessoas equivale a ajudá-las a se tornarem cientes do KAIZEN.

Ciro Yoshinaga 6 coloca a qualidade como filosofia de vida, ou seja, ela está presente no dia-a-dia, inclusive no relacionamento entre as pessoas. A qualidade está em fazer certo a coisa certa, na primeira vez e sempre. Toda vez que alguém reclama de alguma coisa, está exigindo qualidade; por isso, é de se perguntar: será que as pessoas que exigem qualidade em tudo que consomem, oferecem qualidade em tudo aquilo que fazem?

Bérgamo 7 apresenta três definições. A primeira afirma que qualidade é conformidade com as especificações. A segunda, 0 atendimento das necessidades dos consumidores. A terceira, adequação ao uso.

Juran $\mathbf{8}$ defende que, dois significados prevalecem na definição da qualidade:

A qualidade consiste nas características do produto que vào ao encontro das necessidades dos clientes e dessa forma proporcionam a satisfação em relação ao produto.

A qualidade é a ausência de falhas. 
Deming 9 ressalta que a qualidade pode ser definida somente em termos de agente, e lança uma interrogação: quem é o juiz da qualidade?

Nas diferentes situações enumeradas, as respostas direcionam para a figura do consumidor, razão de ser das entidades e parte mais importante de uma linha de produção. Sem consumidor para comprar os produtos, as indústrias encerrariam suas atividades. Portanto, conhecer as necessidades dos consumidores e se antecipar a elas é vital à sobrevivência das entidades.

Crosby $\mathbf{1 0}$ considera que as diferentes perspectivas de um determinado consumidor diante do significado da palavra 'qualidade' justifica defini-la como conformance to requirements, isto é, conformidade com os requisitos. Assim, uma não-conformidade detectada significa falta (ausência) de qualidade.

Ishikawa ${ }^{11}$ observa que a interpretação que se dá ao termo qualidade é importante. O termo 'qualidade', sentido restrito, significa qualidade do produto e, sentido amplo, qualidade de trabalho, qualidade de serviço, qualidade de informação, qualidade de processo, qualidade de divisão, qualidade de pessoal, qualidade de sistema, qualidade de empresa, qualidade de objetivo, etc. $O$ enfoque básico é controlar a qualidade em todas as suas manifestações. Ishikawa afirma, também, que

não importa o quanto a qualidade é alta, se o produto está caro demais, ele não satisfará o consumidor. Em outras palavras, não se pode definir qualidade sem considerar o preço. Não pode haver controle de qualidade que ignore preço, lucro e controle de custos. 
Observa-se que, com exceção da visão do KAIZEN, todas as definições apresentadas, de certa forma, colocam o atendimento às necessidades do cliente como sendo o núcleo para um entendimento comum da palavra qualidade no contexto deste trabalho, sem contudo desprezar as demais definições, à medida que estas permitem uma compreensão mais abrangente da sua importância e significado.

\subsection{Normas de gestão e garantia da qualidade}

A questão da qualidade e da necessidade de implementar sistemas de garantia de qualidade ganhou corpo principalmente entre as entidades exportadoras, no final da década de 80 , com a iminência de unificação dos países integrantes da comunidade européia que passariam a formar um bloco econômico, exigindo, entre outras medidas, a implantação de sistemas de garantia de qualidade como condição de comercialização.

Foi a partir daí que um maior volume de entidades começou a ter preocupações com a qualidade de seus produtos e serviços. Não que esta preocupação não existisse; o ponto é que sem um sistema efetivo, implementado, documentado e que permitisse sua rastreabilidade seria impossível convencer terceiros de que sua entidade opera com padrões de qualidade internacionalmente reconhecidos.

Neste contexto e com subseqüente referendo da $A B N T$, foi que as normas da ISO começaram a ser procuradas como instrumento capaz de atender à demanda por sistemas de gestão e garantia da qualidade. 
Não que a adoção dos padrões internacionais da ISO signifique a Qualidade Total tão almejada pelas entidades. Alguns autores defendem, inclusive, que a adoção dos padrões internacionais da ISO significa, na maioria das vezes, um mal necessário, isto é, um estágio intermediário na busca da qualidade total. De outra forma, a ISO série 9.000 visa somente a "documentar o que estamos fazendo"12 de certo e de errado e é por esta razão que algumas entidades, ao implementar o sistema de garantia da qualidade de acordo com a ISO série 9.000, não obtiveram melhorias.

\subsubsection{Sistema de gestão da qualidade}

As diretrizes para implementação de um sistema de gestão da qualidade de acordo com o padrão internacional ISO 9.004, são apresentadas a seguir para que posteriormente se possa estabelecer, através do ciclo da qualidade, os elos que poderão, eventualmente, propiciar ao auditor contábil o desempenho de um papel na auditoria do sistema de garantia da qualidade.

\subsubsection{Responsabilidade da administração}

Além do comprometimento com as questões da qualidade e da definição das políticas e dos objetivos da qualidade, a alta administração é responsável pelo sistema da qualidade.

Um sistema da qualidade é o conjunto composto pela estrutura organizacional, pelas responsabilidades, pelos procedimentos, processos e demais recursos necessários à implementação da gestão da qualidade. 
Cabe à alta administração a responsabilidade de desenvolver, estabelecer e implementar um sistema de garantia da qualidade que permita o cumprimento das políticas e dos objetivos estabelecidos, e forneça adequada confiança de que o sistema é bem entendido e eficaz, que os produtos e serviços efetivamente atendem às expectativas do cliente e que privilegia a prevenção, ao invés da detecção, isto é: identifica os problemas antes que eles ocorram.

\subsubsection{Princípios do sistema da qualidade}

Um sistema da qualidade deve ter cinco princípios básicos: o ciclo da qualidade, a estrutura, a documentação, a auditoria e a análise crítica. A Figura 2.1. resume os princípios do sistema da qualidade. 


\section{FIGURA 2.1. - PRINCÍPIOS DO SISTEMA DA QUALIDADE}

\begin{tabular}{|c|c|c|}
\hline ITEM & PRINCÍPIO BÁSICO & INTERPRETAÇÃO \\
\hline 2.2.1.2.1 & O ciclo da qualidade & $\begin{array}{l}\text { Compreende todas as atividades relacionadas com } \\
\text { a qualidade de um produto ou serviço, tendo como } \\
\text { objetivo a satisfação do cliente. }\end{array}$ \\
\hline 2.2.1.2.2 & A estrutura & $\begin{array}{l}\text { Recursos humanos, materiais, tecnológicos e } \\
\text { financeiros suficientes devem ser fornecidos para } \\
\text { implementação das políticas da qualidade e para } \\
\text { que se atinjam os objetivos da qualidade. }\end{array}$ \\
\hline 2.2 .1 .2 .3 & A documentação & $\begin{array}{l}\text { Todos os documentos gerados pelo sistema de } \\
\text { gestão da qualidade devem estar disponíveis, } \\
\text { devem ser legíveis e devem estar ordenados e } \\
\text { datados. }\end{array}$ \\
\hline 2.2 .1 .2 .4 & A auditoria & $\begin{array}{l}\text { Todos os componentes do sistema de gestão da } \\
\text { qualidade devem ser auditados e avaliados } \\
\text { periodicamente. }\end{array}$ \\
\hline 2.2.1.2.5 & A análise crítica & $\begin{array}{l}\text { Pessoas habilitadas e independentes devem } \\
\text { elaborar análise crítica do sistema de gestão da } \\
\text { qualidade, incluindo o resultado de auditorias. }\end{array}$ \\
\hline
\end{tabular}




\subsubsection{1. $\quad$ ciclo da qualidade}

O ciclo da qualidade compreende todas as atividades relacionadas com a qualidade do produto ou serviço de uma entidade, desde a identificação inicial até a satisfação final dos requisitos e expectativas do cliente, envolvendo, portanto, toda a estrutura organizacional. 
FIGURA 2.2 - CICLO DA QUALIDADE

Fonte: ISO 9.004 
O ciclo da qualidade pode variar de acordo com o tipo de atividade desenvolvida por uma entidade, geralmente incluindo as seguintes fases e atividades:

\subsection{Marketing e pesquisa de mercado}

Devido à sua proximidade com o cliente e com o mercado, a função marketing é muito importante para o estabelecimento de requisitos da qualidade do produto, quer determinando a necessidade de um produto, quer determinando a demanda e o setor de mercado ou determinando as exigências do cliente.

A função marketing deve, também, prover, através de um documento formal, uma descrição dos requisitos do produto, incluindo, por exemplo, as características de desempenho, condições ambientais, normas e regulamentos legais aplicáveis, embalagens etc.

Cabe ainda à função marketing estabelecer um sistema de realimentação de informações pertinentes à qualidade do produto ou serviço de forma contínua.

\subsection{Engenharia de projeto/especificação e desenvolvimento de produto}

Com base nas informações do produto formalmente descritas pela função marketing, a função especificação e projeto deve traduzir as necessidades do cliente em especificações técnicas para materiais, produtos e processos que permitam sua produção, verificação e controle, nas condições propostas de produção, instalação e operacionalização. 
Ao planejar e estabelecer os objetivos do projeto, a alta administração deve atribuir responsabilidades a todas as atividades com ele relacionadas e assegurar: a) conscientização das pessoas envolvidas quanto à obtenção da qualidade; b) que a função projeto proporcione dados técnicos claros e definitivos para a função aquisição; c) a execução do trabalho e verificação da conformidade de produtos e processos com os requisitos especificados; e d) estabelecer cronograma de projetos, incluindo pontos de verificação apropriados à natureza do produto.

Nesta fase de planejamento, o projetista deve levar em consideração todos os aspectos relativos a regulamentos de segurança, ambiente, leis, além das necessidades do cliente. Ressalte-se que os aspectos da qualidade do projeto devem ser claros, definindo critérios de aceitação e rejeição, segurança contra uso indevido, entre outros.

Durante as fases de projeto e produção, os métodos de medição e ensaio e os critérios de aceitação aplicados na avaliação do produto e dos processos devem ser especificados. Já o processo de qualificação e validação do projeto deve prover avaliações periódicas em estágios significativos. O resultado dos ensaios e avaliações deve ser documentado.

Ao término de cada fase, deve ser realizada uma análise crítica, documentada, sistemática e formal dos resultados do projeto. A principal atribuição do grupo responsável por esta análise é a identificação e antecipação de problemas, dando início às ações corretivas, para assegurar a conclusão satisfatória do projeto.

A função especificação e projeto encerra com a elaboração de uma análise crítica para determinar se a capacidade de produção e suporte de campo são 
adequados para o produto novo ou reprojetado, e com a definição de procedimentos que assegurem o controle sobre o projeto (alterações, liberações, documentação, etc.) e o estabelecimento de reavaliações periódicas do produto, para assegurar que o projeto ainda é válido com respeito a todos os requisitos especificados.

\subsection{Aquisição}

A aquisição de suprimentos deve ser planejada e controlada. $O$ programa da qualidade na aquisição deve incluir no mínimo:

a) requisitos para especificações, desenhos e ordens de compra

Com base nas especificações do projeto, a função aquisição deve desenvolver métodos apropriados para garantir que os requisitos para suprimento sejam claramente definidos, comunicados e completamente compreendidos pelo fornecedor.

b) seleção de fornecedores qualificados

Os fornecedores devem comprovar sua capacidade de fornecer suprimentos, que possa atender a todos os requisitos das especificações do projeto sobre garantia da qualidade.

Um entendimento claro deve ser desenvolvido com o fornecedor sobre a garantia da qualidade. Este entendimento pode variar desde uma mera confiança que o comprador atribui à sua inspeção de recebimento ou 
seleção até sistemas formais de garantia da qualidade, como, por exemplo, uma norma ISO.

c) acordo sobre métodos de verificação

A forma como o comprador verificará a conformidade dos requisitos deve ser acordada com o fornecedor.

d) disposições para dirimir divergências relativas à qualidade

Estabelecer canais de comunicação cada vez melhores entre o comprador e o fornecedor para discussão de assuntos que afetam a qualidade.

e) planejamento e controle da inspeção de recebimento

Garantir que os fornecimentos recebidos sejam controlados corretamente, prevenir que fornecimentos não-qualificados sejam inadvertidamente utilizados e assegurar que as ferramentas, calibres, medidores, instrumentos e equipamentos necessários estarão disponíveis e aferidos, calibrados corretamente, além de pessoal adequadamente treinado.

f) registro da qualidade de recebimento

Devem ser mantidos registros de identificação de lote para fins de rastreabilidade (auditabilidade) e outros que permitam avaliar o desempenho do fornecedor e tendências da qualidade. 


\subsection{Planejamento e desenvolvimento de processo}

O planejamento das operações de produção deve assegurar que estas sejam executadas sob condições controladas, na forma e seqüência especificadas. As práticas correntes no processo de produção devem ser documentadas e referenciadas. Pontos de verificação da qualidade ao longo do processo de produção devem ser estabelecidos e os resultados das verificações devem ser documentados. Esforços para desenvolvimento de novos métodos de melhoria da qualidade devem ser estimulados. O processo de produção deve assegurar que as suas características e as do produto permaneçam dentro do especificado ou que sejam alterados, se for o caso.

Os materiais auxiliares e as utilidades devem ser controlados e verificados periodicamente para assegurar a uniformidade de seu efeito no processo de produção.

\subsection{Produção}

O controle da produção leva em consideração, entre outras coisas, o controle de deterioração e de vida útil em estoque; a rastreabilidade dos materiais ao longo do processo de produção; controle e manutenção preventiva dos equipamentos, incluindo computadores utilizados em controle de processo e os respectivos programas "softwares"; controles mais freqüentes sobre processos especiais que sejam importantes para a qualidade do produto; controle da documentação, incluindo instruções de trabalho, especificações desenhos etc.; controle de alterações de processo; controle do estado de verificação dos materiais e dos 
conjuntos devem ser identificados ao longo da produção; e controle de materiais não-conformes.

\subsection{Inspeção, ensaio e exame}

Além de métodos para assegurar a qualidade dos materiais comprados, inspeções ou ensaios devem ser considerados em pontos apropriados no processo, a fim de verificar a conformidade. Estas verificações podem incluir: ajuste da máquina e inspeção da primeira peça; inspeção ou ensaio automático; inspeções em postos fixos dispostos a intervalos ao longo do processo, entre outros. Complementarmente, podem ser feitas verificações do produto acabado através de ensaios de aceitação ou através de auditoria da qualidade de produto em amostras escolhidas. Esta verificação complementar pode fornecer uma rápida realimentação para as ações corretivas de produto e processo.

Controle dos equipamentos de medição e ensaio utilizados para desenvolvimento, produção, instalação e assistência técnica deve ser mantido para prover confiança e segurança nas decisões ou ações baseadas em dados de medição. Este controle é extensivo a todos os fornecedores de bens e serviços.

Ações corretivas devem ser tomadas sempre que um desvio for identificado; uma avaliação deve ser feita para determinar o trabalho realizado e para saber qual o melhor procedimento a seguir: refazer ou rejeitar? 


\subsection{Embalagem e armazenamento}

O manuseio e o armazenamento de materiais devem ser adequados às suas características e portanto, devem obedecer às suas condições de transporte, temperatura etc.. Os ítens armazenados devem ser verificados periodicamente para detecção de eventual deterioração.

Os materiais devem ser identificáveis através de marcação e etiquetagem ao longo de todo o processo, isto é, desde o recebimento até à entrega no destino final. A embalagem deve conter instruções quanto a métodos de limpeza e de preservação do produto.

\subsection{Vendas e distribuição}

Durante todas as fases da expedição as disposições para proteger a qualidade do produto são importantes. Os ítens que requeiram cuidados especiais, durante o transporte, por exemplo, devem ser identificados.

\subsection{Instalação e operação}

Devem existir instruções escritas que forneçam uma correta orientação de como o produto deve ser instalado e operado. 


\subsection{Assistência técnica e manutenção}

Ferramentas ou equipamentos utilizados no manuseio ou assistência técnica ao produto durante e após a instalação devem ter seu projeto e função validados como qualquer produto novo. Estes equipamentos devem ser controlados.

\subsection{Disposição após uso}

Relatórios de mercado e supervisão de produto para reportar falhas ou deficiências de produto devem ser estabelecidos. Um sistema de realimentação relativo ao desempenho do produto durante o seu ciclo de vida deve ser estabelecido para analisar, de modo contínuo, o grau segundo o qual o produto ou serviço satisfaz as expectativas do cliente quanto à qualidade. As reclamações, falhas e quaisquer ocorrências surgidas durante a utilização do produto ou serviço devem estar disponíveis para análise crítica do projeto e ação corretiva.

\subsubsection{A estrutura}

A alta administração é responsável pelo estabelecimento da política da qualidade e pelas decisões que envolvam o sistema de gestão da qualidade. As responsabilidades e autoridade pela qualidade devem ser identificadas e documentadas. A estrutura organizacional deve ser claramente estabelecida, de tal forma que as linhas de autoridade e comunicação sejam definidas. Recursos humanos, materiais tecnológicos e financeiros suficientes devem ser fornecidos para implementação das políticas da qualidade e alcance dos objetivos da qualidade. 
Fazem parte também da estrutura do sistema de qualidade os procedimentos operacionais. Estes procedimentos devem ser escritos de forma clara e indicar os métodos a serem utilizados e os critérios a serem atendidos, além dos objetivos e desempenho das atividades relacionadas com a qualidade.

\subsection{A documentação}

Todos os documentos gerados pelo sistema de gestão da qualidade, da fixação dos objetivos, políticas, procedimentos da qualidade, à documentação de subcontratados devem estar disponíveis, ser legíveis e estar ordenados e datados.

Um documento fundamental no sistema de gestão da qualidade é o Manual da Qualidade, onde geralmente está descrito todo o sistema de gestão da qualidade com suas interfaces, servindo como referência indispensável à sua implementação e manutenção.

Projetos relativos a novos produtos, serviços ou processos devem incluir os planos da qualidade, definindo, entre outros: os objetivos da qualidade a serem atingidos; as responsabilidades, os procedimentos, métodos e instruções, bem como os programas de ensaios, inspeção, exame e auditoria. Assim, os planos de qualidade são documentos importantes e devem estar disponíveis.

O sistema de gestão da qualidade requer ainda a manutenção de registros suficientes para demonstrar ter sido atingida a qualidade requerida e verificar que sua operação é eficaz. 
O período de manutenção desta documentação deve ser especificado pela alta administração que deve considerar para tanto, um período que permita a realização de análises e permita identificar tendências da qualidade, as necessidades e a eficácia das ações corretivas.

\subsection{A auditoria}

O sistema de gestão da qualidade requer que todos os seus componentes sejam auditados e avaliados periodicamente. Assim, um plano de auditoria deve ser definido e executado e seus resultados devem ser submetidos em forma documentada para apreciação da alta administração da entidade.

\subsection{A análise crítica}

Pessoas habilitadas e independentes devem elaborar análise crítica e avaliação do sistema de gestão da qualidade, incluindo o resultado de auditorias, a eficácia global do sistema de gestão da qualidade para atingir os objetivos e considerações para sua atualização em face das novas tecnologias, conceitos de qualidade, etc.

\subsubsection{Economia - Custos da qualidade}

O sistema deve mensurar seus custos em termos empresariais, com o objetivo de avaliar sua eficácia e estabelecer base para programas internos de melhorias.

Os custos da qualidade são todos aqueles custos incorridos para atingir e garantir níveis especificados de qualidade, incluindo custos de prevenção e avaliação, 
custos de falhas internas e externas, custos de garantia da qualidade externa, por exemplo o custo de uma cláusula de garantia incluída num contrato.

O custo da qualidade deve, sempre que possível ser relacionado com outras medidas de desempenho que permitam à alta administração avaliar a adequação e eficácia do sistema de gestão da qualidade, identificar áreas que requeiram atenção ou mesmo estabelecer objetivos em relação aos custos da qualidade.

\subsubsection{Não-conformidade}

Este item da diretriz detalha os passos que devem ser seguidos sempre que ocorrerem indicações de que os materiais e componentes ou produtos acabados não satisfazem ou podem não satisfazer os requisitos especificados. Identificados os ítens ou lotes suspeitos de não-conformidade, estes devem ser segregados e analisados criticamente, a fim de determinar se podem ser utilizados como estão ou se devem ser reparados ou sucateados. As etapas para tratamento dos iíens ou lotes não-conformes devem estar fixadas em procedimentos documentados .

A fim de evitar a repetição de não-conformidades medidas, de prevenção devem ser tomadas; dentre elas destaca-se a criação de um arquivo relacionando as não-conformidades.

\subsubsection{Ação corretiva}

Uma ação corretiva decorre da detecção de um problema relacionado com a qualidade e requer medidas para eliminar ou minimizar a repetição de um problema. Embora a coordenação das ações corretivas devam ser confiadas a 
uma função específica, todas as funções têm a responsabilidade de analisar e executar ações corretivas.

A relevância de um problema deve ser avaliada em todos os aspectos e uma investigação da(s) causa(s) do problema deve ser determinada e a(s) causa(s) analisada(s) antes de se planejarem medidas preventivas, visto que uma ação preventiva pode envolver mudanças no processo de produção, de embalagem e, portanto, devem ser consideradas com muito critério em face da magnitude do problema detectado. Quando medidas preventivas forem implementadas, seus efeitos devem ser acompanhados para assegurar que as metas desejadas sejam alcançadas. As alterações permanentes, resultantes de ações corretivas, devem ser registradas nas instruções de trabalho, nos processos de produção, nas especificações do produto e/ou no sistema de gestão da qualidade.

\subsubsection{Pessoal}

Trata-se de um item de grande relevância no sistema de gestão da qualidade, a começar pela identificação de necessidades de treinamento em todos os níveis (executivo, gerência, técnicos, supervisores e pessoal da produção). As pessoas envolvidas em funções-chave para a qualidade devem ter qualificação comprovada e avaliada.

Os fatores motivacionais são muito importantes e começam pela compreensão que a pessoa tem das tarefas que lhe são incumbidas e do modo como estas contribuem para as atividades globais. É importante conscientizar as pessoas das vantagens de um trabalho bem executado em todos os níves e das 
conseqüências de um desempenho abaixo das expectativas do trabalho sobre outros empregados, satisfação do cliente e bem-estar econômico da entidade.

Além disso, a conscientização para qualidade deve ser enfatizada; um programa continuado de conscientização deve ser implementado de modo que estes iniciem ações corretivas e outros métodos.

A alta administração deve prover reconhecimento do desempenho quando são atingidos níveis de qualidade satisfatórios.

\subsubsection{Segurança e responsabilidade civil pelo fato do produto}

Devem ser tomadas medidas para limitar o risco relativo à responsabilidade civil pelo fato do produto e minimizar o número de casos através de identificação de normas relativas à segurança; realização de ensaios de qualificação do produto; análise de instruções e advertências para o usuário, de manuais de manutenção e de materiais de identificação e promoção; e desenvolvimento de um meio de rastreabilidade, para facilitar o recolhimento de um produto, no caso de detecção de características que comprometam a segurança, e para permitir uma investigação planejada de produtos ou serviços suspeitos de apresentar características inseguras.

\subsubsection{Uso de métodos estatísticos}

A utilização de métodos estatísticos modernos é um elemento importante em todas as fases do ciclo da qualidade. 


\subsubsection{Sistema de gestão da qualidade: algumas considerações}

Estes requisitos do sistema de gestão da qualidade são, em resumo, prérequisitos para implementação de um sistema de garantia da qualidade, isto é, preparar, organizar, planejar, estruturar internamente a entidade desde a declaração de sua missão, passando pelo processo de conscientização do pessoal e funcionamento do sistema de gestão da qualidade até o seu controle.

É claro que, na busca de um sistema de garantia da qualidade o desenvolvimento e a implementação dos sistemas de gestão e de garantia da qualidade acabam por ocorrer paralelamente. Contudo, do ponto de vista didático, é importante ter a visão de que somente após a implementação do sistema de gestão da qualidade é que a entidade estaria habilitada a implementar um sistema de garantia da qualidade, que, resumidamente, abordaremos a seguir.

\subsubsection{Sistema de garantia da qualidade}

A série ISO 9.000 oferece três modelos para implementação de sistemas de garantia da qualidade, vide item 2.2; abordaremos a seguir o padrão ISO 9.001 Sistemas da qualidade - Modelo para garantia da qualidade em projetos/desenvolvimento, produção, instalação e assistência técnica; é o chamado modelo completo, que engloba todas as fases do processo de garantia da qualidade.

Tendo como base o sistema de gestão da qualidade ISO 9.004, o Modelo para garantia da qualidade apresenta vinte requisitos para o sistema de qualidade. 


\begin{tabular}{|c|c|c|}
\hline ITEM & REQUISITO & INTERPRETAÇÃO \\
\hline 2.2.2.1 & $\begin{array}{l}\text { Responsabilidade da } \\
\text { administração }\end{array}$ & $\begin{array}{l}\text { A alta administração é responsável pelo sistema de } \\
\text { garantia da qualidade. }\end{array}$ \\
\hline 2.2.2.2 & Sistema da qualidade & $\begin{array}{l}\text { Traduz os princípios do sistema de garantia da } \\
\text { qualidade em atividades. }\end{array}$ \\
\hline 2.2.2.3 & Análise crítica de contrato & $\begin{array}{l}\text { Busca assegurar que os requisitos estão } \\
\text { adequadamente definidos e documentados, que as } \\
\text { divergências estão acordadas e que a entidade tem } \\
\text { capacidade de atender os requisitos contratuais. }\end{array}$ \\
\hline 2.2.2.4 & Controle de projeto & $\begin{array}{l}\text { Assegurar que os requisitos específicos sejam } \\
\text { alcançados. }\end{array}$ \\
\hline 2.2.2.5 & Controle de documentos & $\begin{array}{l}\text { Assegurar que a documentação adequada e } \\
\text { atualizada esteja disponível ao longo do sistema. }\end{array}$ \\
\hline 2.2.2.6 & Aquisição & $\begin{array}{l}\text { Assegurar que os produtos ou serviços adquiridos } \\
\text { estão em conformidade com os requisitos } \\
\text { especificados. }\end{array}$ \\
\hline 2.2.2.7 & $\begin{array}{l}\text { Produtos fornecidos pelo } \\
\text { comprador }\end{array}$ & $\begin{array}{l}\text { Estabelecer e manter um procedimento para } \\
\text { verificação, armazenagem e manutenção desses } \\
\text { produtos e ou serviços. }\end{array}$ \\
\hline 2.2.2.8 & $\begin{array}{l}\text { Identificação e } \\
\text { rastreabilidade do produto }\end{array}$ & $\begin{array}{l}\text { Os produtos e serviços devem ser identificáveis em } \\
\text { qualquer estágio do projeto. }\end{array}$ \\
\hline 2.2.2.9 & Controle de processos & $\begin{array}{l}\text { Assegurar que entradas, processamento e saídas } \\
\text { da produção sejam adequadamente controladas. }\end{array}$ \\
\hline
\end{tabular}




\begin{tabular}{|c|c|c|}
\hline ITEM & REQUISITO & INTERPRETAÇÃO \\
\hline 2.2.2.10 & Inspeção e ensaios & $\begin{array}{l}\text { Garantir que os materiais adquiridos somente são } \\
\text { utilizados se estiverem de acordo com os requisitos } \\
\text { especificados. }\end{array}$ \\
\hline 2.2.2.11 & $\begin{array}{l}\text { Equipamentos de } \\
\text { inspeção, medição e } \\
\text { ensaios }\end{array}$ & $\begin{array}{l}\text { Garantir que os equipamentos e dispositivos } \\
\text { utilizados no procedimento de inspeção, medição e } \\
\text { ensaios são controlados. }\end{array}$ \\
\hline 2.2.2.12 & $\begin{array}{l}\text { Situação da inspeção e } \\
\text { ensaios }\end{array}$ & $\begin{array}{l}\text { Assegurar que somente produtos aprovados sejam } \\
\text { despachados, usados ou instalados. }\end{array}$ \\
\hline 2.2.2.13 & $\begin{array}{l}\text { Controle de produto não- } \\
\text { conforme }\end{array}$ & $\begin{array}{l}\text { Evitar que produtos não conformes sejam } \\
\text { indevidamente ou inadvertidamente despachados, } \\
\text { usados ou instalados. }\end{array}$ \\
\hline 2.2.2.14 & Ação corretiva & $\begin{array}{l}\text { Identificar as causas primárias da não-conformidade } \\
\text { e tomar medidas corretivas. }\end{array}$ \\
\hline 2.2.2.15 & $\begin{array}{l}\text { Manuseio,. } \\
\text { armazenamento, } \\
\text { embalagem e expedição }\end{array}$ & $\begin{array}{l}\text { Preservar e manter a qualidade dos materiais } \\
\text { recebidos. }\end{array}$ \\
\hline 2.2.2.16 & Registros da qualidade & $\begin{array}{l}\text { Manter registros legíveis, identificáveis em relação } \\
\text { aos produtos envolvidos. }\end{array}$ \\
\hline 2.2.2.17 & $\begin{array}{l}\text { Auditorias internas da } \\
\text { qualidade }\end{array}$ & $\begin{array}{l}\text { Averiguar se as atividades de qualidade estão em } \\
\text { conformidade com a forma planejada e determinar a } \\
\text { eficácia do sistema de garantia da qualidade. }\end{array}$ \\
\hline 2.2.2.18 & Treinamento & $\begin{array}{l}\text { Todo o pessoal que executa atividades que } \\
\text { influenciam na qualidade deve ser constantemente } \\
\text { treinado. }\end{array}$ \\
\hline 2.2.2.19 & Assistência técnica & $\begin{array}{l}\text { Manter procedimentos para assistência técnica dos } \\
\text { produtos. }\end{array}$ \\
\hline 2.2.2.20 & Técnicas estatísticas & $\begin{array}{l}\text { Auxiliar no controle do ciclo da qualidade, na } \\
\text { determinação da capacidade do processo e } \\
\text { possibilitar a constatação de tendências. }\end{array}$ \\
\hline
\end{tabular}

\subsubsection{Responsabilidade da administração}

A alta administração é em última análise a grande responsável pelo sistema de garantia da qualidade. É de sua responsabilidade, entre outras coisas: 
- definir uma política da qualidade, incluindo os objetivos e o compromisso com a mesma;

- definir mecanismos que assegurem que a política da qualidade seja compreendida, implementada e mantida em todos os níveis da entidade;

- definir e delegar responsabilidades a todo o pessoal que administra, executa e verifica atividades que influem na qualidade;

- identificar pontos de controle do sistema de garantia da qualidade e designar pessoas treinadas para a execução das atividades fornecendo-lhes os recursos necessários para o bom desempenho dessas atividades de verificação, que incluem entre outras coisas a auditoria do sistema de garantia da qualidade;

- designar um pessoa que tenha responsabilidade e autoridade definidas para gerenciar o sistema de garantia da qualidade;

- efetuar, periodicamente, uma análise crítica do sistema implementado, para que sua adequação e eficácia sejam asseguradas; e

- manter registros adequados do sistema de garantia da qualidade.

\subsubsection{Sistema da qualidade}

Considerando os princípios do sistema da qualidade que incluem o ciclo da qualidade, a estrutura do sistema de qualidade, a documentação do sistema, a auditoria do sistema da qualidade e a análise crítica e avaliação do sistema de 
gestão da qualidade, a entidade deve assegurar que o produto ou serviço esteja em conformidade com os requisitos especificados.

Uma forma de traduzir em atividades a captação e a formalização dos princípios que norteiam o sistema incluiria:

- preparação de um Manual da Qualidade definindo as políticas e planos para a qualidade, procedimentos, instruções de trabalho, documentação, dados de referência, interfaces e registro da qualidade, entre outros;

- identificação de controles,. processos, equipamentos de inspeção, etc., necessários para atingir a qualidade requerida;

- atualização constante das técnicas de controle da qualidade;

- identificação dos requisitos necessários à medição e desenvolvimento dos processos;

- definição clara dos padrões de aceitabilidade de todas as características e requisitos;

- compatibilização do processo desde o projeto até à assistência técnica e documentação aplicável; e

- identificação e preparação de registros da qualidade que devem ser mantidos para demonstrar a obtenção da qualidade requerida e a efetiva operação do sistema da qualidade. 


\subsubsection{Análise crítica do contrato}

Deve-se considerar a abrangência do termo "contrato", que inclui desde um contrato formal, escrito, com todos os detalhes envolvendo a transação, até uma simples ordem de fornecimento.

Ao analisar esses contratos, a entidade deve assegurar-se de que:

- os requisitos estão adequadamente definidos e documentados;

- as divergências estão acordadas; e

- a entidade tem capacidade de atender aos requisitos contratuais.

\subsubsection{Controle do projeto}

O controle do projeto deve assegurar que os requisitos específicos sejam alcançados e, para tanto, deve incluir o planejamento, o desenvolvimento, a identificação e documentação dos inputs para o projeto, bem como os dados resultantes do projeto. Além disso, pessoas qualificadas devem ser designadas para as funções de verificação. Procedimentos apropriados para identificação, documentação, análise e aprovação de todas as alterações e modificações ocorridas no projeto devem ser mantidos. 


\subsubsection{Controle de documentos}

O controle de documentos deve assegurar que documentação adequada e atualizada esteja disponível ao longo do sistema e que as alterações efetuadas sejam analisadas criticamente antes de aprovadas.

\subsubsection{Aquisição}

Observado o conteúdo mínimo que um programa de qualidade na aquisição deve conter, vide item 2.2.1.2.1.3 acima, a entidade deve se assegurar que os produtos ou serviços adquiridos estão em conformidade com os requisitos especificados.

Além disso, uma avaliação dos fornecedores e subfornecedores deve ser feita e documentada. Os dados necessários à aquisição do produto ou serviço devem estar claramente definidos.

Quando devidamente acordado entre as partes, o comprador deve ter o direito de verificar na fonte ou no ato do recebimento que o produto ou serviço adquirido esteja em conformidade com os requisitos especificados.

\subsubsection{Produto fornecido pelo comprador}

A entidade deve estabelecer e manter um procedimento para verificação, armazenagem e manutenção dos produtos ou serviços fornecidos por clientes, os 
quais serão incorporados aos produtos ou serviços fornecidos pela entidade àqueles clientes.

\subsubsection{Identificação e rastreabilidade de produto}

Os produtos devem ser identificáveis em todos os estágios, desde o projeto até à expedição e instalação. Quando a rastreabilidade é um requisito especificado, os produtos individualmente ou em lotes devem ter uma identificação única e esta identificação deve ser adequadamente registrada.

\subsubsection{Controle de processo}

O controle de processo objetiva assegurar que as entradas, as condições de processamento da produção e as saídas sejam adequadamente controladas. Assim, materiais, procedimentos, informações, pessoas, tecnologia, habilidades, equipamentos e instalações são dados de entrada que devem estar sob controle.

\subsubsection{Inspeção e ensaios}

A entidade deve garantir que os materiais adquiridos somente são utilizados se estiverem de acordo com os requisitos especificados. Eventuais exceções devem ser identificadas e adequadamente documentadas. A inspeção e os ensaios devem ser feitos durante o processo de produção. Exemplos: a inspeção dos primeiros lotes produzidos e a retenção de amostras até que as inspeções e os ensaios sejam concluídos. A inspeção e os ensaios finais devem exigir que as inspeções e ensaios em estágios anteriores tenham sido efetuados e documentados e que suas conclusões atendam aos requisitos especificados. 


\subsubsection{Equipamentos de inspeção, medição e ensaios}

Todos os equipamentos e dispositivos utilizados no procedimento de inspeção, medição e ensaios devem ser controlados a fim de prover confiança nas decisões ou ações baseadas em dados obtidos através deste procedimento. Além disso, a rastreabilidade da aferição/calibração em relação a padrões oficialmente reconhecidos deve ser garantida.

\subsubsection{Situação da inspeção e ensaio}

A situação da inspeção e ensaio deve ser claramente identificada ao longo do processo, através de etiquetas, selos, rótulos etc., identificando a conformidade ou não do produto. Os registros devem identificar a responsabilidade pela liberação de produtos conformes, assegurando que somente produtos aprovados sejam despachados, usados ou instalados.

\subsubsection{Controle de produtos não conformes}

Os produtos não conformes em relação aos requisitos especificados devem ser controlados para que não sejam indevidamente ou inadvertidamente instalados. Estes produtos devem passar por uma análise crítica feita por pessoas habilitadas e autorizadas pela alta administração para decidirem sobre retrabalho, aceitação, reclassificação ou rejeição/sucateamento. 


\subsubsection{Ação corretiva}

A ação corretiva, em linhas gerais, visa a determinar a causa primária da não conformidade com os requisitos especificados antes de planejar as medidas preventivas e colocá-las em prática para eliminar ou minimizar a repetição de um problema.

\subsubsection{Manuseio, armazenamento, embalagem e expedição}

No manuseio, na armazenagem, na embalagem e na expedição dos produtos deve-se preservar e manter a qualidade de materiais recebidos, de produtos em processo e de produtos acabados, até que cheguem ao cliente.

\subsubsection{Registros da qualidade}

Os registros da qualidade são a prova documental da qualidade requerida e da efetiva operação do sistema de garantia da qualidade. Estes registros devem ser legíveis, identificáveis em relação aos produtos envolvidos, e arquivados, por um período determinado, numa ordem que permita sua pronta recuperação, quando necessário.

\subsubsection{Auditorias internas da qualidade}

O sistema de auditoria interna da qualidade deve ser abrangente, planejado e documentado, para verificar se as atividades da qualidade estão em conformidade com a forma planejada e para determinar a eficácia do sistema da qualidade. 
As auditorias internas devem ser planejadas tendo por base a situação do sistema da qualidade e a importância das atividades dentro do sistema.

Os resultados das auditorias internas devem ser documentados e levados ao conhecimento tanto do responsável pela atividade auditada como da alta administração. O objetivo é que as ações corretivas sejam tomadas em tempo hábil.

\subsubsection{Treinamento}

Todo o pessoal que executa atividades que influem na qualidade deve ter suas necessidades de treinamento identificadas e documentadas. Este pessoal deve ser qualificado e estar constantemente motivado para a qualidade.

\subsubsection{Assistência técnica}

O sistema de garantia da qualidade deve estabelecer e manter procedimentos para assistência técnica dos produtos especialmente, quando esta for uma obrigação contratual.

\subsubsection{Técnicas estatísticas}

As técnicas estatísticas devem ser aplicadas em todas as fases do ciclo da qualidade ou onde apropriado. É muito importante adequar a técnica estatística à situação a ser controlada para auxiliar na determinação da capacidade do processo e possibilitar a constatação de tendências. 


\subsubsection{Sistema de garantia da qualidade: algumas considerações}

Talvez pela própria origem do papel que a área de controle de qualidade desempenha ao longo do tempo nas entidades, observa-se uma preocupação singular, contida nos padrões da série ISO 9.000, com relação às funções Inspeção e ensaios, revelando que, embora não sistematizada no nível organizacional, o controle de qualidade exercido por estas áreas continha 0 núcleo do sistema de garantia da qualidade que a série ISO 9.000 acabou por expandir para a organização como um todo.

Esta reflexão nos leva à inevitável confrontação entre um sistema de garantia da qualidade, cujo núcleo é o atendimento das necessidades do cliente com ênfase na qualidade do produto, com outro, cujo núcleo é também o atendimento das necessidades do cliente, mas com ênfase na qualidade das pessoas.

Embora não seja objetivo deste trabalho firmar conclusão sobre a reflexão proposta, há de se refletir sobre o assunto, visto que durante o processo de implementação dos padrões ISO 9.000 esta questão, a meu ver, deve ser considerada atribuindo-se ênfase maior à qualidade das pessoas. 


\section{NOTAS}

1 Campos, Vicente Falconi. Gerência da Qualidade Total, Belo Horizonte MG, Block Editores S.A. 1989, prefácio.

2 International Standard ISO 8.402 - Quality -Vocabulary, 1986, p. 2.

3 Campos, Vicente Falcini. TQC Controle da Qualidade Total (no estilo japonês), Belo Horizonte - MG, Block Editores S.A., 1992, p. 2.

4 Lobo, Júlio. Qualidade através das pessoas, São Paulo, Câmara Brasileira do Livro, 1991, p. 14.

5 Imai, Masaaki. KAIZEN: A estratégia para o sucesso competitivo - 3 a Edição, Tradução de Cecilia Fagnani Lucca, São Paulo, Instituto de Movimentação e Armazenagem de Materiais - IMAM, 1990, p. XVII.

6 Yoshinaga, Ciro. Qualidade Total: A forma mais prática e econômica de implementação e condução, São Paulo, 1988, p. 6.

7 Bérgamo Filho, Valentino. Os caminhos da qualidade e da produtividade: Como entender os conceitos da qualidade de um modo simples e gostoso, São Paulo, Editora Edgar Blücher Ltda, 1991, pp. 1 e 2.

8 Juran, Joseph Moses e Gryna, Frank M. Controle da qualidade handbook. Conceitos, políticas e filosofia da qualidade. - Tradução Maria Cláudia de 
Oliveira Santos, Revisão técnica TQS Engenharia - São Paulo, Makron, McGraw-Hill, 1991, p. 11.

9 Deming. William Edwards. Out of the crisis - Massachusetts, Massachusetts Institute of Technology, 13th printing, April 1991, pp. 168-175.

10 Crosby, Philip B. Quality is free. The Art of Making Quality Certain - New York, McGraw-Hill Book Company, p. 17.

11 Ishikawa, Kaoru. Controle da qualidade total: à maneira japonesa Tradução de lliana Torres, Rio de Janeiro, Campos, 1993, p.44.

12 O'Hanlon, Tim. O auditor líder. Uma história sobre auditoria de sistemas daqualidade, Tradução de Mônica F.H. Cavalcanti, São Paulo, Editora Pioneira, 1994, p. XXIV. 
Dentro do contexto de sistemas de gestão e garantia da qualidade discutiremos neste Capítulo as normas de auditoria da qualidade fixadas pelo ISO e a importância da auditoria nos sistemas de gestão e garantia da qualidade. Discutiremos, também, uma abordagem de auditoria da qualidade com o objetivo de estabelecer um parâmetro de comparação com a abordagem de auditoria contábil, que será discutida no Capítulo 4, estabelecendo, assim, as bases para uma discussão sobre os caminhos possíveis para a atuação do auditor contábil na auditoria de sistema de garantia da qualidade.

\subsection{As normas de auditoria da qualidade}

O papel que a auditoria representa no sistema de gestão e garantia da qualidade é tão importante a ponto de ser imprescindível ao seu bom funcionamento.

Esta importância foi reconhecida pela ISO, quando esta emitiu tanto diretrizes normatizando tanto a atividade de auditoria como, critérios para qualificação de auditores e diretrizes para condução de programas de auditoria da qualidade: 


\subsubsection{Diretrizes para auditoria de sistemas da qualidade - Parte 1}

\section{Auditoria}

As diretrizes estabelecem:

a) objetivos e responsabilidades da auditoria, destacando-se a impossibilidade de transferência de responsabilidade entre auditor e auditado, cabendo ao auditado a responsabilidade pela obtenção da qualidade nas operações;

b) funções e responsabilidades dos auditores e dos auditados destacando-se a importância e a necessidade de independência do auditor em relação aos objetivos da auditoria. Esta independência deve ser em todos os sentidos; e

c) regras gerais de auditoria a serem observadas desde o início, na preparação, na execução, na documentação e ao término da auditoria, e no acompanhamento de ações corretivas.

As normas, por serem regras gerais, não entraram no mérito dos procedimentos de auditoria, uma vez que estes variam de acordo com as circunstâncias específicas de cada auditoria.

Um detalhe importante constante da norma diz respeito à não-obrigatoriedade do auditor em apresentar recomendações ao auditado, reiterando que a responsabilidade pela determinação e implementação de ações corretivas é exclusiva do auditado. O auditor pode, quando solicitado, apresentar 
recomendações que visem à melhoria do sistema de gestão e garantia da qualidade;

\subsubsection{Diretrizes para auditoria de sistemas da qualidade - Parte 2 Critérios para qualificação de auditores de sistema da qualidade}

A pessoa do auditor merece uma atenção especial, pois da sua qualificação e da maneira como seu trabalho é conduzido depende, basicamente, a eficácia de uma auditoria da qualidade. Ao estabelecer critérios para qualificação de auditores de sistema de garantia da qualidade, através do documento ISO 10.011-2, a ISO evidencia esta preocupação.

Fixando normas desde o grau mínimo de escolaridade (2ํㅡ grau completo), passando pela necessidade de treinamento contínuo, de experiência acumulada, competência comprovada, domínio do idioma utilizado no local da auditoria, além de outros atributos de ordem pessoal, tais como; dignidade, capacidade de julgamento, capacidade de análise, mentalidade aberta, entre outros, a ISO procura garantir a qualidade dos auditores e, por conseguinte, das auditorias da qualidade.

Um ponto a ser destacado nesta norma refere-se à manutenção da competência do auditor. É recomendável que, periodicamente, os auditores passem por um processo de reavaliação de sua capacitação para execução de suas funções, estabelecendo-se, assim, um processo de retro-alimentação entre a pessoa do auditor e os sistemas de gestão e garantia da qualidade. 


\subsubsection{Diretrizes para auditoria de sistemas da qualidade - Parte 3 Gestão de programas de auditoria}

Estas diretrizes são aplicáveis ao estabelecimento e manutenção de uma função de gestão do programa de auditoria, na execução de auditorias de sistemas de garantia da qualidade, conforme os padrões internacionais ISO.

O conteúdo deste documento inclui diretrizes para qualificação da equipe de auditores, bem como sua adequação aos propósitos específicos das auditorias. Inclui, também, diretrizes para o monitoramento e manutenção do desempenho do auditor ressaltando a necessidade de treinamento. Inclui ainda diretrizes para os fatores operacionais, tais como; comprometimento de recursos, planejamento e cronograma do programa de auditorias, relatórios de auditoria, verificação de ações corretivas, confidencialidade, auditorias conjuntas e melhoria contínua do programa de auditoria. Por fim, o documento inclui a necessidade de elaboração de um código de ética tanto para a execução das auditorias como para gestão do programa de auditoria.

\subsection{O que é auditoria da qualidade?}

Exame sistemático e independente para determinar se as atividades da qualidade e seus resultados estão de acordo com as disposições planejadas, se estas foram efetivamente implementadas e se são adequadas à consecução dos objetivos. ${ }^{1}$

Ao apresentar esta definição, a Norma ISO destaca em nota os seguintes pontos que devem ser considerados para o pleno entendimento de seu conteúdo a saber: 
- Aplicabilidade e propósitos da auditoria da qualidade, ou seja, se esta se aplica essencialmente aos sistemas de qualidade, incluindo seus elementos, produtos, serviços e processos e pode ser executada com propósitos internos e externos à entidade; $\mathrm{e}$

- Independência e agregação de valor da auditoria da qualidade, ou seja, os auditores não podem ser diretamente responsáveis pelas áreas objeto da auditoria mas, devem, de preferência, ser pessoas cooperativas, que trabalhem em conjunto com o auditado objetivando à melhoria dos sistemas de gestão e garantia da qualidade, agregando, assim, valor ao seu trabalho.

Rebelo $^{2}$ define auditoria da qualidade como

uma atividade formal e documentada, executada por pessoal habilitado, que não tenha responsabilidade direta na execução do serviço em avaliação e que, ao se utilizar do método de coleta de informações baseado em evidências objetivas e imparciais, fornece subsídios para a verificação da eficácia do Sistema da Qualidade.

Para Juran $\mathbf{3}$ auditoria da qualidade, em termos gerais,

é uma análise independente, conduzida com o fim de comparar alguns aspectos do desempenho da qualidade com um padrão para aquele desempenho.

Juran enfatiza a utilização do termo "independente" no sentido de que o auditor não pode nem deve ter nenhuma responsabilidade sobre o desempenho a ser auditado. 
Campos $^{4}$, de forma mais pragmática, ao invés de definir, classifica a auditoria da qualidade em três tipos: auditoria de sistema; auditoria de processo: e auditoria de produto, explicitando seus objetivos específicos. Nesta ótica, a auditoria da qualidade é definida nas seguintes dimensões:

- auditoria de sistema - tem por objetivo verificar se a política da qualidade e o sistema da qualidade são perfeitamente compreendidos e praticados no di-a-a dia conforme planejado;

- auditoria de processo - tem por objetivo verificar se todos os processos e demais procedimentos operacionais - inclusive aferição/calibragem, de instrumentos, ferramentas e equipamentos, e educação/treinamento do pessoal - estão seguindo os padrões preestabelecidos e se estes estão atualizados; e

- auditoria de produto - tem por objetivo verificar se os produtos que sofreram inspeção atendem plenamente às exigências e necessidades da qualidade.

O objetivo contributivo, ou seja, aquele que consiste em agregar valor ao auditado, deve nortear a auditoria da qualidade independentemente da sua tipologia, finaliza Campos, ao afirmar que "o produto de uma auditoria deve ser a orientação, o conselho."

Gil5 defende que a auditoria da qualidade visa à validação e à avaliação de pontos de controle da qualidade total, os quais podem ser subdivididos em:

a) pontos de controle da qualidade operacional, em função de serem identificados no horizonte empresarial "passado presente"; e 
b) pontos de controle da qualidade da gestão, em função de serem identificados no horizonte empresarial "presente futuro".

Gil ressalta a importância da independência da função auditoria em relação ao ponto de controle da qualidade total atribuindo a este o "status" de entidade unitária/básica/pilar do processo de auditoria da qualidade total.

Para os propósitos deste trabalho, utilizaremos a definição de auditoria da qualidade incluída na norma ISO por ser genérica e, portanto, mais abrangente, servindo tanto às finalidades internas como externas.

\section{3 \\ Objetivos da auditoria da qualidade}

O item 4.1 da Norma ISO 10.011-1 relaciona os seguintes objetivos:

- determinar a conformidade ou não-conformidade dos elementos do sistema da qualidade com requisitos especificados;

- determinar a eficácia do sistema da qualidade implementado no atendimento aos objetivos da qualidade especificados;

- prover ao auditado a oportunidade de melhorar o sistema da qualidade;

- atender aos requisitos regulamentares; e

- permitir o cadastramento do sistema da qualidade da organização auditada em um registro.

Yoshinaga $^{6}$ enumera cinco objetivos, a saber:

1. Proporcionar aos gerentes uma visão profunda da Organização (Empresa). 
2. Assegurar a existência de sistemas que permitam à organização cumprir suas exigências contratuais (com os clientes).

3. Servir como ferramenta para se levantar a SITUAÇÃO ATUAL, com a finalidade de obter melhoria contínua.

4. Conferir os Sistemas da Qualidade Organizacional existentes com base em normas conhecidas, com o objetivo de descobrir as não-conformidades.

5. Assegurar que os procedimentos existentes estão sendo seguidos e propor treinamento onde for necessário.

Juran ${ }^{7}$ menciona que os objetivos normais das auditorias da qualidade são fornecer garantia independente de que:

- Os planos para atingir a qualidade são tais que, se seguidos, a qualidade pretendida será, de fato, obtida.

- Os produtos são adequados ao uso e seguros para o usuário.

- As leis e regulamentações estão sendo seguidas.

- Existe conformidade com as especificações.

- Os procedimentos são adequados e estão sendo seguidos.

- O sistema de dados fornece informações precisas e adequadas da qualidade a todos os envolvidos.

- As deficiências são identificadas e a ação corretiva, tomada.

- As oportunidades para aperfeiçoamento são identificadas e o pessoal encarregado, alertado. 
Gil8 afirma que

o objetivo primordial da auditoria da qualidade é assegurar à alta administração a efetividade do sistema da qualidade vigente/praticado pela organização e estabelecer seu nível/intensidade em termos de:

- evolução histórica via variação das mensurações, ou, notas aplicadas às fraquezas dos Pontos de Controle da Qualidade flagrados;

- benchmarket pelo confronto de nossa organização com outras organizações concorrentes, ou não, e o conseqüente estabelecimento quantitativo da sensibilidade da auditoria, em relação à intensidade das fraquezas identificadas/apontadas e correlacionadas entre todas essas organizações;

- 'arbitragem' dos anseios/desejos/necessidades empresariais preestabelecidos, em diversos níveis da organização, por exemplo, através de 'contratos de gestão', ou através dos orçamentos.

- perspectivas/facilidade da qualidade futura, segundo planejamento/simulações/montagem de cenários/identificação de tendências realizadas (momento auditoria da qualidade da gestão).

Observa-se que, de maneira geral, os objetivos de auditoria da qualidade são comuns, permitindo um direcionamento às ações dos auditores no que se refere à abordagem de auditoria da qualidade, a qual inclui planejamento, execução e controle no contexto do sistema de gestão e garantia da qualidade discutidos no Capítulo 2. 
Independente da forma da auditoria, isto é, auditoria interna ou externa, a definição clara dos objetivos da auditoria da qualidade é determinante no planejamento da auditoria e, por conseguinte, na sua execução e nos resultados que se espera obter.

A figura 3.1. ${ }^{9}$ classifica as auditorias da qualidade em internas e externas:

\section{FIGURA 3.1. - CLASSIFICAÇÃO DAS AUDITORIAS DA QUALIDADE}

\begin{tabular}{|ll|}
\hline AUDITORIA EXTERNA & AUDITORIA INTERNA \\
\hline - do fornecedor pelo comprador & - pelo Presidente* \\
- para certificação & - pelo Chefe da Unidade \\
- por Consultor ou empresa & - pelo Setor de Controle da Qualidade \\
consultora & para obtenção do prêmio Deming*
\end{tabular}

* existem somente no Japão.

As auditorias da qualidade podem combinar diferentes classificações resultando em tipos distintos. Por exemplo, a publicação Industrial Quality Program $\mathbf{1 0}$ apresenta classificações que consideram a localização organizacional, a seqüência cronológica e as atividades a serem cobertas.

a) localização organizacional - interna ou externa - (onde) 
A auditoria interna é definida como uma investigação de programas de garantia da qualidade sob controle direto da entidade, fazendo parte de sua estrutura organizacional. Exemplo: auditoria de um sub-sistema dentro da mesma entidade.

A auditoria externa é definida como uma investigação de programas de garantia da qualidade que não estão sob controle direto da entidade, não fazendo parte de sua estrutura organizacional. Exemplo: auditoria de um fornecedor.

b) seqüência cronológica - momento - (quando)

\section{$\underline{\text { Auditoria de pré-qualificação técnica - Pre-Award }}$}

É definida como sendo uma investigação de programas de garantia da qualidade de fornecedores potenciais, antes da expedição dos pedidos de compra ou assinatura de contratos.

Este tipo de auditoria tem por objetivo averiguar se os fornecedores potenciais têm condições reais de atender aos requisitos aplicáveis de qualidade, não só nos produtos, mas também nos processos e no sistema de garantia da qualidade. Uma auditoria deste tipo inclui a verificação de equipamentos, instrumentos de medição, máquinas, qualificação da mãode-obra, etc...

Auditoria de acompanhamento - Post-Award 
É definida como sendo uma investigação de programas de garantia da qualidade de fornecedores após a colocação do pedido de compra ou assinatura do contrato e durante a fase de produção dos ítens ou serviços adquiridos.

\section{Auditoria de Follow-up}

É definida como uma re-investigação de subsistemas auditados anteriormente, para verificar se ações corretivas para as nãoconformidades apontadas foram implementadas e se mostraram eficazes.

\section{$\underline{\text { Auditoria suplementar }}$}

É definida como uma auditoria especial, em adição às auditorias programadas quando ocorrerem mudanças substanciais no programa da qualidade, na estrutura organizacional ou na qualidade do produto ou serviço.

c) atividades a serem cobertas (o quê)

\section{Auditoria do programa}

É definida como uma avaliação da existência de um programa de garantia da qualidade e da sua documentação, para verificar se atende aos requisitos do cliente e à política de qualidade da entidade. 


\section{Auditoria do produto}

É definida como uma análise dos produtos ou serviços apresentados por uma entidade para avaliação da real eficácia do seu programa de garantia da qualidade.

\section{$\underline{\text { Auditoria do processo }}$}

É definida como uma avaliação da eficácia de um programa de qualidade, através de análise do processo produtivo, verificando se os métodos e procedimentos são adequados e se são cumpridos na prática real.

\section{$\underline{\text { Auditoria do sistema }}$}

É definida como uma avaliação dos sistemas funcionais individuais previstos no programa da qualidade, para verificar se são cumpridos pelo pessoal e se são eficazes.

\section{$\underline{\text { Auditoria parcial }}$}

É definida como um exame parcial do programa de qualidade, com avaliação de apenas determinadas partes cada vez.

Além das classificações apresentadas existem inúmeras outras decorrentes de combinações de objetivos que resultam em diferentes tipos de auditoria. Exemplo: auditoria do processo, interna, de acompanhamento. 
A amplitude da auditoria da qualidade pode variar da simples verificação de um procedimento especificado até à verificação do sistema de gestão e garantia da qualidade como um todo. Os limites dessa amplitude estão na obtenção de certeza, através de evidências objetivas, de que os registros da qualidade são confiáveis e suficientes e atendem aos objetivos da qualidade especificados para a unidade objeto da auditoria.

Embora seja responsabilidade da alta administração prover recursos necessários ao bom desempenho das atividades relacionadas à garantia da qualidade, não há como negar que o aspecto econômico é um fator limitante da amplitude da auditoria da qualidade. Para serem economicamente viáveis, as auditorias da qualidade, independentemente da forma (externa ou interna), são executadas tendo como base testes seletivos. Assim, quanto mais o auditor ampliar seus testes, menor será o risco de que não-conformidades deixem de ser identificadas e reportadas ao auditado. Contudo, quanto maior a amplitude, maior o custo. A utilização de técnicas. como amostragem estatísticas ou aleatórias e planos de rotação, entre outras, contribuem para o equacionamento do aspecto econômico nas auditorias de sistemas de garantia da qualidade.

As qualificações necessárias a um auditor da qualidade são decisivas para reconhecer e estabelecer as limitações inerentes de cada auditoria. Está implícito, pois, no estabelecimento de uma abordagem de auditoria da qualidade o exercício de julgamento do auditor, onde limitações e riscos são diretamente proporcionais. Este julgamento sempre será feito pelo auditor líder responsável pelo processo de auditoria como um todo. 

de garantia da qualidade

As partes envolvidas (auditor e auditado) têm responsabilidades que devem ser assumidas durante todo o processo de auditoria da qualidade. Um exemplo que ilustra bem esta questão é a responsabilidade pela obtenção da qualidade. $O$ auditado jamais poderá ou deverá transferir para o auditor a responsabilidade pela obtenção da qualidade, pois esta é inerente ao auditado.

\subsubsection{As responsabilidades do auditado}

Entre as inúmeras responsabilidades do auditado no processo de auditoria da qualidade destacam-se:

a) definição da oportunidade e dos objetivos da auditoria dando início ao processo;

b) prover o auditor ou a equipe de auditores de todos os recursos necessários à consecução de uma auditoria eficiente e eficaz;

c) cooperar com o auditor ou a equipe de auditores facilitando acesso às instalações, às pessoas, à documentação e às informações necessárias para permitir o cumprimento dos objetivos da auditoria por ele definidos; e

d) receber o resultado da auditoria, que são formalizados através de relatórios escritos, e determinar o início das ações corretivas necessárias. 


\subsubsection{As responsabilidades do auditor}

Independência, integridade, valores éticos e competência são características intrínsecas a um auditor, que servem de base para direcionar o cumprimento de suas responsabilidades. Atendidas estas condições no processo de auditoria da qualidade, destacam-se as seguintes responsabilidades:

a) Definir um plano de auditoria da qualidade que atenda às necessidades específicas do auditado e/ou contratante e programar auditores capacitados para a execução do plano, isto é, o auditor ou a equipe de auditores deve incluir profissionais com conhecimento especializado. Exemplo: se o escopo da auditoria inclui o sistema metrológico, o auditor ou algum membro da equipe de auditoria deverá possuir sólidos conhecimentos de metrologia para que o resultado da auditoria seja eficaz para o auditado e/ou contratante;

b) Obter corroboração do auditado e/ou contratante para o plano de auditoria da qualidade antes da sua execução;

c) Executar o plano de auditoria da qualidade de acordo com os objetivos definidos, procurando sempre manter-se dentro do escopo, isto é, cumprindo todos os requisitos aplicáveis da auditoria;

d) Manter postura ética durante todo o processo de auditoria da qualidade; 
e) Identificar, documentar - através de evidências objetivas - e relatar todas as não-conformidades que vieram ao seu conhecimento durante a execução da auditoria, existentes no sistema de gestão e garantia da qualidade;

f) Elaborar e apresentar ao auditado e/ou contratante, em tempo hábil, um relatório circunstanciado, de exceções, documentando formalmente o resultado da auditoria, incluindo, caso existam, todas as não-conformidades identificadas; e

g) Quando incluso no escopo da auditoria, verificar a eficácia das ações corretivas adotadas em função do resultado de auditorias anteriores (o chamado "follow-up").

\subsection{A abordagem de auditoria de sistemas de garantia da qualidade}

Num ambiente empresarial e dentro de uma visão sistêmica, onde o sistema de gestão e garantia da qualidade é parte integrante do sistema de controle interno da entidade, a auditoria da qualidade é entendida como um processo que recebe inputs, processa-os e emite outputs.

Neste trabalho, a abordagem apresentada está fortemente baseada no enfoque de auditoria das demonstrações contábeis desenvolvido pela empresa DELOITTE TOUCHE TOHMATSU Auditores Independentes11, acrescido das adaptações necessárias ao pleno atendimento das normas de auditoria dos sistemas de garantia da qualidade, e considera a independência plena do auditor em relação 
ao auditado, ou seja, a abordagem apresentada serve tanto para auditorias internas como para externas.

O processo da auditoria de sistemas de garantia da qualidade pode ser abordado através de uma seqüência lógica de atividades divididas em três fases. A figura 3.2. sumariza estas fases e as atividades desenvolvidas. 
FIGURA 3.2. - FASES E ATIVIDADES NA AUDITORIA DA QUALIDADE

PLANEJAMENTO

EXECUÇÃO

CONTROLE

\begin{tabular}{c} 
ATIVIDADES \\
DE \\
PRÉ-AUDITORIA \\
\hline
\end{tabular}

ATIVIDADES

DURANTE A

EXECUÇÃO

\begin{tabular}{c}
\hline ATIVIDADES \\
DE \\
PÓS-AUDITORIA \\
\hline
\end{tabular}

\begin{tabular}{|c|}
\hline ATIVIDADES \\
\hline DE \\
\hline CONTROLE \\
\hline
\end{tabular}

\begin{tabular}{|c|}
\hline AVALIAR OS \\
OBJETIVOS DA \\
AUDITORIA \\
\hline
\end{tabular}

REUNIÃO INICIAL

PREPARAÇÃO DO
RELATÓRIO DE
AUDITORIA

PERIODICIDADE DAS AUDITORIAS

ESTABELECER
CONDIÇÕES PARA
EXECUÇÃO DA
AUDITORIA
EXECUÇÃO DO PLANO DE AUDITORIA

REVISÃO DE
QUALIDADE

CUSTO DAS AUDITORIAS

\begin{tabular}{|c|}
\hline COMPREENDER O \\
SISTEMA DE GESTÃO E \\
GARANTIA DA \\
QUALIDADE
\end{tabular}

AVALIAR O
RESULTADO DA
AUDITORIA

\begin{tabular}{c} 
FOLLOW-UP DAS \\
AÇÕES CORRETIVAS \\
\hline
\end{tabular}

\begin{tabular}{l} 
RODÍZIO DE \\
AUDITORES \\
\hline
\end{tabular}

\section{COMPREENDER O} PROCESSO DE REGISTRO DA QUALIDADE

COMPREENDER $O$ AMBIENTE DE CONTROLE DA QUALIDADE

\begin{tabular}{c} 
LISTAR AS \\
NÃO- \\
CONFORMIDADES \\
\hline REUNIÃO FINAL \\
\hline
\end{tabular}

QUALIDADE DAS AUDITORIAS

QUALIFICAÇÃO DOS AUDITORES

AVALIAR OS RISCOS

DESENVOLVER O
PLANO DE AUDITORIA




\subsubsection{Planejamento da auditoria}

As atividades desenvolvidas nesta fase são classificadas como atividades de préauditoria, por englobar todo o processo desde a aceitação da auditoria até o desenvolvimento do plano de auditoria que atenda aos objetivos estabelecidos pelo auditado e/ou contratante.

\subsubsection{Avaliar os objetivos da auditoria}

Antes de qualquer outra atividade, é preciso entender e avaliar os objetivos da auditoria e os riscos existentes para sua execução. Nesta etapa devem ficar claros o objetivo da auditoria, as responsabilidades do auditor e do auditado e a forma do relatório.

\subsubsection{Estabelecer condições para execução da auditoria}

O entendimento obtido com relação aos objetivos da auditoria, as responsabilidades das partes, bem como a forma do relatório devem ser documentados, assegurando formalmente todas as condições necessárias para a execução da auditoria de forma eficaz.

\subsubsection{Compreender o sistema de gestão e garantia da qualidade}

Compreender o sistema de gestão e garantia da qualidade em suficiente detalhe para: 
- avaliar o Manual da Qualidade da entidade.

- identificar todos os subsistemas que integram o sistema de gestão e garantia da qualidade e suas interfaces.

- avaliar as políticas da qualidade e como são praticadas ao longo do sistema.

- estar ciente das preocupações da alta administração com as questões da qualidade.

- entender a estrutura organizacional e identificar os processos utilizados pela alta gerência para gerir o sistema de garantia da qualidade.

- entender os tipos de processos utilizados e os tipos de produtos produzidos pela entidade.

\subsubsection{Compreender o processo de registro da qualidade}

Adquirir uma compreensão geral do processo de registro da qualidade. Como resultado desta compreensão, deve-se identificar os registros e os procedimentos utilizados para identificar, processar e registrar as evidências objetivas de que o programa de qualidade é efetivo e eficaz.

\subsubsection{Compreender o ambiente de controle da qualidade}

É fundamental observar o comportamento das pessoas - especialmente a alta administração - e seu nível de conscientização em relação às questões da 
qualidade. Esta observação é particularmente importante para determinar a priori o nível de confiança que o auditor poderá depositar no sistema.

\subsubsection{Avaliar os riscos}

A avaliação de riscos para o auditor está relacionada com a possibilidade de que não-conformidades relevantes não sejam identificadas durante o processo de auditoria. Assim, o auditor deve considerar riscos indicados por experiências anteriores, riscos decorrentes de um ambiente de controle inadequado, riscos associados aos registros da qualidade, etc.

Esta avaliação de riscos fornece subsídios e consistência ao plano de auditoria, auxiliando na escolha do caminho mais adequado para a realização da auditoria, visando ao cumprimento dos objetivos estabelecidos pelo auditado e/ou contratante.

\subsubsection{Desenvolver o plano de auditoria}

Todas as atividades desenvolvidas nos ítens anteriores devem ser traduzidas em um plano de trabalho, ou melhor, no plano de auditoria a ser executado. Este documento deverá conter no mínimo as seguintes informações:

- Os objetivos da auditoria e as condições necessárias à sua consecução;

- O entendimento do auditor sobre o sistema de gestão e garantia da qualidade;

- A compreensão do auditor sobre o processo de registro da qualidade; 
- A compreensão do auditor sobre o ambiente de controle relacionado às questões da qualidade;

- Os riscos identificados e os procedimentos específicos que serão executados para eliminar ou minimizar sua ocorrência;

- A estratégia de auditoria a ser executada incluindo os procedimentos detalhados para cada subsistema auditado (lista de verificação);

- Demais informações necessárias à consecução da auditoria, tais como, pessoal-chave, organograma funcional, etc.

\subsubsection{Execução da auditoria}

As atividades desenvolvidas nesta fase foram, para fins didáticos, subdividas em dois momentos: o primeiro, atividades durante a execução da auditoria, e o segundo, atividades pós-auditoria. Na prática, estas atividades, embora obedeçam a uma seqüência lógica de execução, possuem certa simultaneidade. Por exemplo, é difícil imaginar que o auditor venha a elaborar seu relatório somente após a execução da auditoria. Na prática, trata-se de um processo integrado, orientado para que todas as evidências objetivas identificadas, que comprovam uma não-conformidade, sejam listadas para, posteriormente, integrar o relatório de auditoria.

\subsubsection{1. $\quad$ Atividades durante a execução da auditoria}


Esta etapa compreende as atividades executadas entre a reunião inicial e a reunião final.

\subsection{Reunião inicial}

Uma reunião inicial e formal deve ser realizada entre auditores, auditados e a alta administração da entidade, incluindo o responsável pelo Sistema de Garantia da Qualidade, com os seguintes objetivos, entre outros:

- Confirmar os objetivos da auditoria;

- Apresentar a equipe de auditoria;

- Comunicar a metodologia a ser utilizada explicando a forma e a seqüência na qual as atividades serão desenvolvidas;

- Enfatizar que a auditoria será ética, justa e construtiva, 12 ressaltando que não haverá surpresas;

- Agendar horários para que não haja perda de tempo; e

- Agendar a reunião final com todos os presentes.

A reunião inicial deve ser breve e o auditor deve aproveitá-la para criar um ambiente descontraído, $\mathbf{1 3}$ com o auditado procurando enfatizar que a auditoria da qualidade sempre busca a conformidade. Não é objetivo principal do auditor da 
qualidade a busca da não-conformidade. Esta, se houver, será uma decorrência natural do processo de auditoria.

\subsection{Execução do plano de auditoria}

Colocar em prática o plano de auditoria requer determinação. O auditor deve desenvolver seu trabalho tendo por base o roteiro (lista de verificação/"check-list") previamente estabelecido. Entretanto, o auditor deve estar consciente de que o roteiro prévio é um caminho a ser seguido e que, eventualmente, em face das situações encontradas, desvios poderão ser percorridos. Em outras palavras, a lista de verificação não é uma camisa-de-força; o auditor deve estar preparado para alterá-la a qualquer momento, sempre que as situações encontradas assim o exijam.

À medida que deficiências do programa de qualidade ou não-conformidades forem identificadas, o auditor deve comunicá-las de imediato ao auditado. Este procedimento é bastante eficaz porque, ao apontar in loco a não-conformidade, o auditor fica numa posição confortável para obter a concordância do auditado bem como a ação corretiva a ser implementada. Caso a concordância não seja obtida de imediato, o procedimento continua sendo válido pois o auditado estará sendo informado da não-conformidade antes de seus superiores hierárquicos.

Um ponto muito importante a ser considerado é o fato de que as nãoconformidades identificadas e solucionadas durante a execução da auditoria não deverão constar do relatório do auditor, pois o propósito da auditoria da qualidade é melhorar a qualidade e reduzir os custos, e não produzir papel ou "mostrar serviço"14. 
A negociação entre auditor e auditado, sobre a conveniência de se incluir no relatório de auditoria as não-conformidades identificadas e solucionadas durante a execução da auditoria, sempre existirá. No entanto, a decisão final de reportar ou não estas não-conformidades será sempre do auditor, que em nenhum momento permitirá que sua independência seja colocada em dúvida.

Durante a execução do plano de auditoria, é importante também destacar os aspectos positivos encontrados, como, por exemplo, um bom programa de treinamento, o nível de comprometimento do pessoal com as questões da qualidade, etc. A menção dos aspectos positivos, além de atender o objetivo de retroalimentar o sistema de garantia da qualidade, serve como fator estimulante para o auditado 15 .

\subsection{Avaliar o resultado da auditoria}

As informações obtidas, as deficiências e não-conformidades encontradas devem ser registradas pelo auditor no momento em que forem identificadas ou observadas, com o objetivo de assegurar que o resultado da auditoria seja apresentado com riqueza de detalhes, que permitirão ao auditado o desenvolvimento e implementação de ações corretivas.

As questões mais complexas devem ser analisadas com maior profundidade pelos auditores, antes que qualquer comentário seja feito ao auditado, inclusive, se for o caso, uma auditoria suplementar deve ser marcada para verificação destas questões complexas. Esta alternativa forneceria ao auditor um tempo maior para analisar as questões e formar sua opinião. 


\subsection{Listar as não-conformidades}

Antes de formalizar ao auditado o resultado da auditoria, a equipe de auditores deve se reunir e trocar informações acerca das observações efetuadas, das nãoconformidades encontradas e, principalmente, sobre a relevância das nãoconformidades. O auditor deve separar as não-conformidades relevantes (deficiências que podem comprometer o sistema de garantia da qualidade) das demais, preparando a lista de não-conformidades que constará do relatório de auditoria.

\subsection{Reunião final}

Uma reunião final e formal deve ser realizada, entre auditores, auditados e a alta administração da entidade, incluindo o responsável pelo Sistema de Garantia da Qualidade, com o objetivo de apresentar o resultado da auditoria. É importante que nesta reunião se obtenha a concordância sobre as deficiências e nãoconformidades encontradas e, sempre que possível, obter do auditado as ações corretivas aplicáveis, prazos e responsáveis por sua implementação.

\subsubsection{Atividades pós-auditoria}

Concluída a reunião final com o auditado e/ou contratante, o auditor inicia o processo de formalização, das atividades executadas e das conclusões alcançadas, através da preparação do relatório de auditoria. 


\subsection{Preparação do relatório de auditoria}

O relatório de auditoria é a forma preferida para comunicar, formalmente, ao auditado e/ou contratante, oportunamente, as não-conformidades identificadas, e quando apropriado, as ações corretivas necessárias, embora estas sejam de responsabilidade do auditado.

\subsection{Revisão de qualidade}

O relatório de auditoria elaborado pelo auditor líder, responsável pelas atividades desenvolvidas e pelas conclusões alcançadas, é submetido a uma revisão de qualidade. Esta revisão, independente, é feita por um auditor que não participou diretamente dos trabalhos e tem por objetivo verificar a adequação do relatório aos objetivos da auditoria. O auditor designado para efetuar a revisão de qualidade deve possuir um nível de experiência similar ou preferivelmente superior à do auditor líder responsável pela execução da auditoria e pela preparação do respectivo relatório.

\subsection{Acompanhamento "follow-up" de ações corretivas}

A implementação e a eficácia de ações corretivas resultantes de auditorias anteriores devem ser avaliadas e documentadas.

O plano de auditoria da qualidade deve contemplar o acompanhamento de todas as ações corretivas identificadas em auditorias anteriores, principalmente para 
avaliar a eficácia das ações corretivas implementadas, ou seja, se estas ações eliminaram satisfatoriamente as não-conformidades que lhe deram origem.

\subsubsection{Atividades de controle}

O controle das auditorias é fundamental num sistema de gestão e garantia da qualidade. Este controle deve ser exercido pelo gestor do programa de auditoria da qualidade, mesmo que estas auditorias sejam conduzidas por empresas especializadas.

\subsubsection{Periodicidade das auditorias}

As auditorias, independentemente de sua natureza, devem ser programadas periodicamente, com base na situação e importância da atividade ou do sistema/subsistema a ser auditado.

Um cronograma de auditoria que equacione as necessidades do auditado com àquelas constantes do sistema de gestão e garantia da qualidade, inclusive a periodicidade das auditorias externas de Certificação e/ou para revalidação da Certificação, deve ser estabelecido.

Este cronograma deverá levar em conta todas estas necessidades, para que não ocorra a situação de excesso de auditorias num determinado período, inclusive auditorias simultâneas, e ausência prolongada em outros. O mérito de um cronograma de atividades de auditoria reside no equacionamento dessas variáveis. 


\subsubsection{Custo das auditorias da qualidade}

É evidente que se deve exercer um controle sobre o custo das auditorias da qualidade quer pela relação com os benefícios alcançados em decorrência das não-conformidades identificadas e das ações corretivas implementadas, quer pela relação com a performance de cada objetivo de auditoria.

Com relação aos benefícios alcançados, a análise é mais objetiva e facilmente percebida.

Com relação à performance de cada objetivo de auditoria, a análise já não é tão objetiva e requer um detalhamento maior, que inclui:

a) o objetivo da auditoria (escopo);

b) o tempo gasto no planejamento, execução e controle da auditoria voltada para aquele objetivo;

c) a experiência e qualificação do auditor ou da equipe de auditoria encarregada do serviço;

d) a situação atual e importância da atividade objeto da auditoria; e

e) o tempo gasto em auditorias anteriores voltadas para o mesmo objetivo. 


\subsubsection{Rodízio de auditores}

É recomendável que, após um determinado período ou uma determinada quantidade de auditorias realizadas com o mesmo objetivo, seja efetuada uma troca de auditores ou das equipes de auditoria.

O estabelecimento de um sistema de rodízio de auditores, devidamente monitorado, oferece vantagens a todas as partes envolvidas no processo:

a) auditado

possibilita que pessoas (auditores) com experiência e qualificação diferentes auditem os sistemas/subsistemas sob sua responsabilidade.

b) auditor

possibilita que os auditores conheçam outros sistemas/subsistemas, bem como pessoas com experiência, qualificações e formas de gestão diferentes.

c) ambos

evita que a rotina e o conhecimento mútuo, decorrentes de auditorias anteriores, acabem por revestir a auditoria com um grau de informalidade não recomendável. 


\subsubsection{Qualidade das auditorias}

A auditoria da qualidade deve contribuir/realçar/elevar/alavancar a qualidade total organizacional através de uma atuação ativa 16 . Esta responsabilidade é parte integrante do processo de auditoria da qualidade, que visa não somente a certificar a conformidade das práticas da qualidade constatadas, em relação àquelas preconizadas, mas, também, a otimizar o sistema da qualidade.

A utilização do melhor recurso tecnológico disponível, aliada ao recurso humano (auditores) adequada e continuamente treinado, formam o binômio necessário à garantia da qualidade da auditoria da qualidade.

A revisão de qualidade discutida no item 3.6.2.2.2 acima é uma das técnicas disponíveis utilizada para garantir a qualidade das auditorias e, por via de conseqüência, a qualidade do sistema de garantia da qualidade.

\subsubsection{Qualificação dos auditores}

Conforme mencionado no item acima, auditores adequada e continuamente treinados são determinantes para a qualidade das auditorias da qualidade. $O$ conhecimento de um auditor da qualidade deve permear toda a atividade empresarial, além, é claro, dos conhecimentos das técnicas de auditoria e do sistema de gestão e garantia da qualidade. 


\subsubsection{Considerações finais}

A abordagem apresentada neste Capítulo teve o objetivo de discutir as normas gerais que norteiam as auditorias de sistemas da qualidade, sem entrar no mérito dos procedimentos de auditoria aplicados em cada uma das fases, visto que estes, conforme mencionamos anteriormente, variam de acordo com os objetivos de cada auditoria e, também, não acrescentariam subsídios relevantes aos objetivos gerais deste trabalho.

\subsection{Estudo de caso: \\ Acompanhamento de auditoria de controle do sistema de garantia da qualidade}

Com o objetivo de obter maiores subsídios para elaboração do presente trabalho, tivemos a oportunidade de acompanhar uma auditoria de controle realizada pela empresa Certificadora "ABS - Quality Evaluation", de origem norte-americana, com larga experiência na execução de auditorias de sistemas de garantia da qualidade.

A empresa visitada é do ramo petroquímico, com aproximadamente 200 colaboradores, sendo $40 \%$ terceirizados (manutenção, armazenamento e expedição, embalagem de produto, entre outras áreas). A referida empresa obteve o Certificado ISO 9.002 em fevereiro de 1993 e em março de 1994 obteve o Certificado ISO 9.001. 
A experiência adquirida forneceu subsídios valiosos para a elaboração do Capítulo 3 e contribuiu decisivamente para um melhor entendimento das questões da qualidade. A seguir, relaciono alguns destes subsídios e algumas constatações:

- Validar a abordagem de auditoria apresentada, à medida que as atividades relatadas refletem o que efetivamente acontece no dia-a-dia dos auditores de sistemas de garantia da qualidade;

- Conhecer na prática como funciona um sistema de garantia da qualidade e constatar que a necessidade do comprometimento das pessoas com a questão da qualidade não se trata de teoria, mas sim, de pura prática, que determina o sucesso na implementação e principalmente na manutenção de um sistema de garantia da qualidade;

- Constatar que o comprometimento da alta administração com o sistema de garantia da qualidade é imprescindível. Empresas nas quais o executivo principal não torna explícito seu comprometimento enfrentam mais dificuldades para manter o sistema. A postura do executivo principal acaba por determinar - grau de comprometimento das pessoas com o sistema de garantia da qualidade. Lobos $\mathbf{1 7}$ afirma que a idiossincrasia dos superiores é um fator que atua como empecilho à qualidade daquilo que as pessoas fazem;

- Constatar que o treinamento contínuo das pessoas envolvidas com a qualidade é um enorme diferenciador. Empresas nas quais o programa de treinamento é continuado e está voltado às necessidades específicas de cada profissional, com o objetivo de que este possa desenvolver melhor suas atividades 
cotidianas, acabam por obter uma contribuição mais efetiva, que pode ser mensurada, por exemplo, pela quantidade e, principalmente, pela qualidade das sugestões recebidas através do programa de qualidade;

- Confirmar a eficácia das iniciativas voltadas a manter a questão da qualidade em contínua evidência. Iniciativas do tipo "Semana da Qualidade", "Café da Qualidade", "Reunião da Qualidade", "Cumbuca", etc., quando pessoas se reúnem para falar sobre qualidade, funcionam como fatores motivacionais à manutenção do sistema de garantia da qualidade. A freqüência destas iniciativas é muito importante. Por exemplo; O Café da Qualidade, na empresa visitada, é diário, com duração de quinze minutos. Já a Cumbuca é feita mensalmente, com duração de duas horas, nessa ocasião o Capítulo de um livro sobre qualidade, previamente escolhido, é discutido pelos participantes. A Semana da Qualidade pode ser um evento anual com programações diversificadas, podendo incluir palestras de clientes, fornecedores e consultores, dramatizações, gincanas, entre outras atividades. As reuniões da qualidade são de freqüência variada sendo realizadas sempre que o grupo julga necessário.

- Firmar conviçcão de que os profissionais da área contábil podem e devem contribuir de forma mais decisiva no processo de gestão dos sistemas de garantia da qualidade. Observei que o papel do contador/controller não deve estar restrito às questões do custo da qualidade, principalmente pelo fato de que os sistemas de informação das empresas, invariavelmente, estão subordinados a estes profissionais. Isto, por si só, poderia dar a dimensão do papel que o contador/controller poderia ou deveria exercer na gestão de um sistema de garantia da qualidade. Contudo, entendo que este papel deve ser 
objeto de um estudo mais aprofundado. Neste trabalho a ótica recai sobre o profissional da área contábil com especialização em auditoria; e

- Confirmar que o auditor contábil pode e deve dar sua contribuição para o aprimoramento dos sistemas de garantia da qualidade. Num ambiente empresarial, a almejada competitividade somente será alcançada com qualidade. Esta qualidade não está restrita à empresa portadora do sistema de garantia da qualidade; trata-se de um processo que envolve clientes e fornecedores (chamados parceiros), conclamando-os a participar do processo e implementar seu próprio sistema de gestão e garantia da qualidade. Diante do exposto, o auditor contábil não poderá furtar-se a este chamamento e, por conseguinte, há de se refletir sobre o papel que deverá desempenhar neste processo. A demanda por esta participação será crescente, à medida que uma quantidade maior de empresas aderir aos programas de qualidade. 


\section{NOTAS}

1 ISO 8.402, Gestão da qualidade e garantia da qualidade - Terminologia

2 Rebelo, Antonio Raimundo Coutinho - Auditorias da qualidade, Artigo publicado na Revista Controle de Qualidade № 17 de outubro de 1993, pp. 12 a 22

3 Juran, Joseph Moses e Gryna, Frank M. - Controle da qualidade handbook. Componentes básicos da função qualidade. Tradução Maria Cláudia de Oliveira Santos, Revisão técnica TQS Engenharia - São Paulo, Makron, McGraw-Hill, 1991, p. 6.

4 Campos, Vicente Falconi - TQC - Controle da qualidade total (no estilo japonês) - 2ª edição, Belo Horizonte-MG, Block Editores S.A.,1992, p. 116.

5 Gil, Antonio de Loureiro - Auditoria da Qualidade - São Paulo, Editora Atlas S.A., 1994, p. 94.

6 Yoshinaga, Ciro - Qualidade Total. A forma mais prática e econômica de implementação e condução, São Paulo, 1988, p. 91.

7 Juran, Joseph Moses e Gryna, Frank M. - Controle da qualidade handbook. Componentes básicos da função qualidade. Tradução Maria Cláudia de Oliveira Santos, Revisão técnica TQS Engenharia - São Paulo, Makron, McGraw-Hill, 1991, pp. 6 e 7. 
8 Gil, Antonio de Loureiro - Auditoria da Qualidade - São Paulo, Editora Atlas S.A., 1994, p. 94.

9 Campos, Vicente Falconi - TQC - Controle da qualidade total (no estilo japonês) - 2ª edição, Belo Horizonte-MG, Block Editores S.A.,1992, p. 154.

10 Stat- A- MAtrix, Inc. - Industrial Quality Program, EUA, 1980.

11 Deloitte Touche Tohmatsu Auditores Independentes - Enfoque de Auditoria - Tradução revisada Agosto/91, pp. 9-23.

12 Caminada Netto, Adherbal - Apostila: Auditorias da Qualidade, p. 3.1.

13 MCG Qualidade, associada à P-E. Batalas - Apostila: Auditorias da Qualidade, p. 9.

14 Caminada Netto, Adherbal - Apostila: Auditorias da Qualidade, p. 3.4..

15 MCG Qualidade, associada à P-E. Batalas - Apostila: Auditorias da Qualidade, p. 12.

16 Gil, Antonio de Loureiro - Auditoria da Qualidade - São Paulo, Editora Atlas S.A., 1994, pp. 94 e 95.

17 Lobos, Júlio - Qualidade através das pessoas, São Paulo, Câmara Brasileira do Livro, 1991, p. 7. 


\subsection{Normas de auditoria}

As chamadas normas de auditoria geralmente aceitas são divididas em três grandes grupos a saber: a) normas gerais; b) normas de trabalho no campo; e c) normas de relatório.

a) As normas gerais voltadas para a pessoa do auditor e contemplam questões como qualificação profissional do auditor (treinamento e capacidade), sua independência em relação aos trabalhos que executa, de forma a manter uma atitude mental independente, e seu zelo profissional tanto na execução do trabalho como na preparação do relatório onde expressa sua opinião.

Uma abordagem de extrema relevância sobre as normas voltadas à pessoa do auditor foi feita por Carvalho, $\mathbf{1}$ ao incorporar a questão da "ética e lucro" e a questão da credibilidade do auditor como uma conjugação de competência e independência. Estas questões não podem ser esquecidas em nenhum momento da atuação profissional do auditor, inclusive no desempenho do seu papel na auditoria de sistemas de garantia da qualidade.

b) As normas de trabalho no campo, voltadas para execução do trabalho desde o planejamento adequado e a época apropriada para execução do trabalho de campo, com destaque para o estudo e avaliação do sistema de controle 
interno, obtenção de elementos comprobatórios e preparação de papéis de trabalho, que darão suporte à emissão da opinião (parecer).

O estudo e avaliação do controle interno é parte fundamental do processo de auditoria das demonstrações contábeis, pois permite ao auditor estabelecer uma base de apoio para determinar a época, extensão, natureza e oportunidade para execução dos demais procedimentos de auditoria. Quando o auditor conclui que pode confiar nos controles internos, seus testes substantivos (comprobatórios) são menos extensivos.

c) As normas do relatório (parecer), voltadas para o conteúdo dos relatórios, destacando a necessidade de adesão aos princípios fundamentais de contabilidade, sua consistência em relação a períodos contábeis anteriores e a adequação das informações contidas nas demonstrações contábeis. Além disso, as normas do relatório (parecer) estabelecem que o relatório do auditor deve expressar uma opinião (parecer) sobre as demonstrações contábeis tomadas como um todo e se houver exceções/ressalvas, estas devem ser reveladas incluindo as razões que a justificam.

\subsection{O que é auditoria contábil ?}

An 'audit' is the independent examination of, and expression of an opinion on, the financial statements of an enterprise. 3

Auditing is a systematic process of objectively obtaining and evaluating existence regarding assertions about economic actions and events to assertain the degree of correspondence between those assertions and established criteria and communicating the results to interested users. 3 
An audit is the independent examination of financial statements or related financial information of an entity, whether profit oriented or not, and irrespective of its size, or legal form, when such an examination is conducted with a view to expressing an opinion thereon. 4

A despeito da utilização de palavras diferentes, as definições acima são igualmente abrangentes. A primeira e a terceira, por não especificarem o tipo de exame, qualificando-os apenas como 'independente'. A segunda, por especificar genericamente o processo de auditoria, ensejando, segundo o próprio $A A A$, de maneira intencional, a abrangência com que uma auditoria pode ser conduzida.

Numa discussão mais detida do conteúdo dessas definições encontram-se algumas questões que restringem ou limitam a referida abrangência de uma auditoria.

A primeira delas é a necessidade de quantificação. As afirmações e os eventos econômicos refletidos nas demonstrações contábeis devem ser quantificáveis para serem auditáveis. A informação quantificável é também verificável; informações não verificáveis, por definição, não são auditáveis5. Uma informação verificável é aquela que pode ser refeita/recomposta/reproduzida de maneira independente, por exemplo: o custo de produção de um determinado produto ou lote de produtos. Contudo, há informações que substancialmente só podem ser verificadas e por tanto auditadas no momento em que ocorrem, por exemplo: o montante em espécie, existente numa determinada data, compondo o saldo do caixa.

Outra restrição reside na obtenção e avaliação das provas/evidências que darão suporte às conclusões alcançadas. Nem sempre a evidência inconteste pode ser 
obtida, impondo ao auditor o uso do julgamento profissional nas circunstâncias mais diversas e obrigando-o a conviver com o risco inerente decorrente destas limitações.

Diante do exposto, podemos afirmar que a auditoria é um exercício de julgamento onde limitação e risco são diretamente proporcionais. Isto é, quanto mais o auditor amplia sua auditoria, menor será o risco de que erros materiais ocorram no processo contábil de preparação das demonstrações contábeis, que, eventualmente, não sejam detectados no processo de auditoria.

O objetivo do exame normal das demonstrações financeiras pelo auditor independente é a emissão de parecer sobre a adequação com que as demonstrações apresentam a posição patrimonial e financeira, o resultado das operações e as modificações na posição financeira, de conformidade com os princípios de contabilidade geralmente aceitos 6 .

Um exame normal das demonstrações contábeis pelo auditor independente implica na observância das normas de auditoria geralmente aceitas, as quais foram resumidamente abordadas no item 4.1 deste trabalho. $O$ cumprimento das normas de auditoria deve ser declarado pelo auditor no corpo de seu relatório.

\subsection{A abrangência da auditoria contábil}

Uma auditoria contábil deve ser suficientemente abrangente, para permitir ao auditor a obtenção de um conjunto de provas/evidências que the forneçam bases razoáveis para formar uma opinião. 
O conjunto de provas/evidências necessário varia de acordo com as circunstâncias de cada auditoria e o processo para sua coleta/obtenção é precedido de uma adequada compreensão dos negócios realizados pela entidade objeto da auditoria, bem como uma adequada compreensão do processo contábil, do ambiente de controle e do sistema de controle interno.

Como parte integrante do conjunto de provas/evidências, o resultado destas atividades preliminares permite ao auditor, tendo como referência básica principalmente a confiança depositada no sistema de controle interno, determinar a natureza, época e extensão dos demais procedimentos de auditoria que irão compor o conjunto de provas/evidências.

A exemplo do que comentamos no item 3.4, não há como negar que o aspecto econômico é um fator limitante da amplitude, também, da auditoria contábil. Contudo, cabe ressaltar mais uma vez a discussão sobre ética e lucro proposta por Carvalho (vide 4.1 acima), tendo agora como objetivo afirmar que, embora seja um fator limitante da amplitude da auditoria contábil, num mercado concorrencial, de forma alguma esta limitação deverá comprometer o conjunto de provas/evidências necessário para que o auditor forme uma opinião sobre as demonstrações contábeis.

A abrangência da auditoria contábil terá seus contornos (limitações versus riscos) definidos em cada circunstância e por cada auditor, tendo por base suas qualificações, competência técnica, experiência profissional e grau de aceitação de riscos. 
Dentro da visão que estamos discutindo neste trabalho, adicionaríamos as normas de gestão e garantia da qualidade como um subsídio a mais ao conjunto de provas/evidências que contribuirá para que o auditor contábil venha a emitir uma opinião (parecer) melhor fundamentada.

\section{5}

As responsabilidades no processo de auditoria contábil

No processo de auditoria contábil as responsabilidades são claramente definidas e distribuídas entre os dirigentes das entidades objeto da auditoria e os auditores contábeis.

Recai sobre o dirigente da entidade objeto da auditoria a responsabilidade pela apresentação apropriada das demonstrações financeiras, pois estas são em última análise representação da empresa.

Sobre o auditor contábil recai a responsabilidade de emitir uma opinião sobre as demonstrações contábeis elaboradas pelos dirigentes da entidade objeto da auditoria, tendo por base as normas de auditoria geralmente aceitas e os princípios fundamentais de contabilidade.

É também responsabilidade da administração a manutenção de um sistema de controle interno que, entre outras coisas, contribua para assegurar a apresentação apropriada das demonstrações contábeis 7 . As transações realizadas ao longo de um período devem ser de conhecimento e controle direto da administração da empresa e estar adequadamente refletidas nas demonstrações contábeis. O conhecimento que o auditor tem dessas transações é limitado àquele adquirido por meio de seu exame. 
Fica subentendido que, sob a ótica do auditor contábil, é também responsabilidade da administração da entidade objeto de auditoria a manutenção do sistema de gestão e garantia da qualidade. $O$ conhecimento que o auditor contábil tem do sistema de gestão e garantia da qualidade é também limitado àquele adquirido por meio de seu exame.

\subsection{A abordagem da auditoria contábil sobre o sistema de controle interno}

A abordagem sobre o sistema de controle interno será efetuada sob a ótica do auditor contábil, que difere da ótica de outros grupos de usuários, principalmente por centrar seu foco nos controles que asseguram a preparação de demonstrações contábeis confiáveis e o cumprimento de leis e regulamentos.

O conhecimento que o auditor contábil adquire sobre o sistema de controle interno de uma entidade é limitado à extensão requerida pelas circunstâncias.

Os antecedentes apresentados no item 4.6.1, aliados à evolução do conceito de controle interno discutida no item 4.6.2, demonstram a importância e a preocupação que diferentes grupos de usuários, com diferentes perspectivas, atribuem ao sistema de controle interno.

A questão da qualidade está diretamente relacionada com a forma como as atividades de uma entidade são gerenciadas e controladas. Neste sentido, o controle interno não está somente integrado ao sistema de gestão e garantia da qualidade; na verdade, ele é crítico para o sucesso de um programa de qualidade. 
Completa o Capítulo uma breve apresentação do ciclo contábil e dos principais pontos de controle interno contábil, que servirão de base para o estabelecimento da matriz de correlação entre o ciclo da qualidade e o ciclo contábil apresentada no Capítulo 5.

\subsubsection{A importância do controle interno - Antecedentes}

Antes de entrar na discussão do conceito de controle interno, entendo oportuno incorporar a este trabalho uma visão sobre os antecedentes, que de forma inequívoca revelam o nível de preocupação que auditores, contadores, administradores, educadores, políticos e autoridades governamentais norteamericanas vêm atribuindo à questão do controle interno nas entidades.

Estes antecedentes serviram de justificativa para que algumas entidades, dentre elas: o AICPA - American Institute of Certified Public Accountants; AAA - American Accounting Association, FEI - Financial Executives Institute; IIA - Institute of Internal Auditors and NAA - National Association of Accountants, se unissem e patrocinassem um estudo mais aprofundado sobre o controle interno. O grupo de trabalho denominado COSO - The Committee of Sponsoring Organizations of the Treadway Commission elaborou o estudo, publicado em 1992, intitulado "Internal Control - Integrated Framework", do qual constam ("Appendix A - Background and events leading to the study"), os antecedentes que reportamos a seguir:

a) Desde os anos 40, os profissionais de contabilidade e auditoria vêm publicando vários pronunciamentos sobre controle interno. Contudo, foi na década de 70 que o assunto ganhou maior evidência, nos Estados Unidos, principalmente, em decorrência das investigações relacionadas com o caso 
WATERGATE. Essas investigações revelaram que várias corporações americanas fizeram ou faziam contribuições ilegais a políticos e pagamentos questionáveis ou ilegais a representantes de governos de outros países.

Como resultado dessas investigações o Congresso norte-americano editou o Ato 1977, Foreign Corruption Practices Act of 1977 (FCPA). O tema central deste Ato focaliza a necessidade de o controle interno ser um efetivo inibidor de pagamentos questionáveis ou ilegais.

b) Já em 1974 ○ AICPA havia formado um grupo denominado Cohen Commission. Este grupo, coordenado por auditores, estudou as responsabilidades dos auditores e apresentou uma recomendação no sentido de que a administração das corporações apresentasse juntamente com as demonstrações contábeis um relatório revelando as condições de seu controle interno. O relatório final deste grupo foi emitido em 1978.

c) Com base no relatório da Cohen Commission, o Instituto de Executivos Financeiros (FEl) enviou carta a seus membros apoiando a recomendação da Cohen Commission, incluindo um guia para auxiliar na implementação da recomendação. Como resultado dessa iniciativa, um relatório de controle interno começou a aparecer com mais freqüência nos relatórios anuais endereçados aos acionistas.

d) Em 1979, a SEC - Securities and Exchange Commission, tendo por base o relatório da Cohen Commission e a iniciativa da FEl, propôs regras para um Relatório da Administração, obrigatório, incluindo revisão dos auditores 
independentes. "Statement of Management on Internal Accounting Control" (SEC Release 34-15772).

Em função das inúmeras críticas recebidas, do custo adicional que traria para as empresas, da propalada irrelevância da informação reportada e, principalmente, devido à proximidade com o Ato de 1977, o que poderia dar a entender que se tratava de uma declaração de cumprimento da Lei, a Securities Exchange Commission foi obrigada a cancelar a referida norma. Contudo, ao recuar na sua proposta, a SEC mencionou que toda emissão pública de relatórios seria revisada. Por trás desta declaração existia a pretensão de, adicionalmente, solidificar o reconhecimento sobre a responsabilidade da Administração das empresas na manutenção de um efetivo sistema de controle interno sobre as informações interinas, e outras informações financeiras divulgadas ao mercado sem terem sido auditadas.

e) Em 1979, o AICPA formou um comitê chamado "Special Advisory Committee on Internal Control", com o objetivo de fornecer diretrizes sobre o estabelecimento e avaliação do controle interno. Este comitê percebeu que a maior parte das diretrizes existentes tinha sido elaborada por profissionais de auditoria e que seria necessário a formulação de diretrizes para auxiliar a Administração a cumprir suas responsabilidades de controle interno.

f) Em 1980, a FERF - Financial Executives Research Foundation publicou estudo, tendo sido sua maior contribuição catalogar as características do controle interno, as condições, as práticas, procedimentos e a identificação de uma grande diversidade de visões com relação à definição, natureza e 
propósito do controle interno e, a forma como um efetivo controle interno deveria ser alcançado.

Em 1981, esse grupo publicou um segundo estudo identificado como critério conceitual para avaliar o controle interno.

g) Durante a década de 80 , os padrões profissionais com relação ao controle interno foram refinados, principalmente, em função da dinâmica de atuação das Comissões Técnicas do AICPA, que emitiu os seguintes padrões:

- 1980, SAS no 30 - Reporting on Internal Accounting Control, que descreve os procedimentos que um auditor independente deve aplicar nos diferentes tipos de serviços, ao reportar sobre o sistema de controle interno contábil de uma entidade;

- 1982, SAS no 43 - Omnibus Statement on Auditing Standards, que inclui um guia revisado sobre as responsabilidades dos auditores independentes no estudo e avaliação do controle interno, para uma auditoria das demonstrações contábeis conduzida de acordo com as normas de auditoria geralmente aceitas;

- 1984, SAS no 48 - The effects of Computer Processing On the Examination of Financial Statements, que inclui a descrição das características de um processamento computadorizado que pode ter efeito sobre o sistema de controle interno contábil; 
- 1988, SAS no 55 - Consideration of the Internal Control Structure in a Financial Statement Audit. Este padrão define melhor os elementos de uma estrutura de controle interno, aumentando a responsabilidade dos auditores independentes em entender e fornecer guias sobre a avaliação de controle de riscos quando executam uma auditoria das demonstrações contábeis.

h) Em 1983, o Institute of Internal Auditors - IIA, emitiu o IAS no 1 - Control: Concepts and Responsibilities, através do qual estabeleceu padrões para os auditores internos.

i) Em 1985, em função do fracasso de algumas empresas e da alegação de fracasso dos auditores independentes, uma subcomissão congressual começou a realizar audiências enfocando uma variedade de eventos, envolvendo companhias abertas que levantaram questões sobre a conduta da Administração, da propriedade dos Relatórios Financeiros e da efetividade da auditoria independente.

Durante as audiências, algumas legislações foram elaboradas, contendo várias medidas, dentre as quais a exigência de que a Administração de companhias abertas avaliasse e reportasse sobre a efetividade do controle interno. Adicionalmente, a legislação incluía medidas exigindo a opinião de auditores independentes sobre a avaliação e relatório preparado pela Administração.

Embora nenhuma Lei tenha sido editada em decorrência dessas audiências, a subcomissão congressual ampliou o escopo de suas audiências considerando 
outros aspectos do processo dos Relatórios Financeiros e mantendo o assunto controle interno em evidência.

j) Ainda em 1985 foi criada a Comissão Nacional sobre Relatórios Fraudulentos conhecida como TREADWAY COMMISSION, que contou com o patrocínio das seguintes entidades: AICPA, AAA, FEI, IIA e NAA e tinha como objetivo principal identificar os fatores causais dos Relatórios Financeiros Fraudulentos e fazer recomendações para reduzir sua incidência.

O relatório dessa comissão, emitido em 1987, incluiu recomendações para os Administradores, Conselhos de Administração das Companhias Abertas, para a Profissão Contábil, para a SEC, para outros orgãos reguladores e para os acadêmicos/educadores.

A comissão fez inúmeras recomendações que visaram ao controle interno, enfatizando a importância do ambiente de controle, do código de conduta, da competência dos comitês de auditoria envolvidos e uma ativa e objetiva função de auditoria interna. Adicionalmente, a comissão convocou as entidades patrocinadoras a trabalhar juntas num projeto para integrar os vários conceitos e definições de controle interno e desenvolver um ponto comum de referência. Foi sugerido que o desenvolvimento de um guia ajudaria as Companhias Abertas a melhorar seus sistemas de controle interno e a julgar sua efetividade.

Com base nessas recomendações, a Comissão elaborou um estudo sobre a literatura de controle interno e recomendou que as entidades patrocinadoras empreendessem um projeto para fornecer critérios práticos, abrangentes e aceitos para estabelecer o controle interno e avaliar sua efetividade. A 
Comissão recomendou que os critérios fossem dirigidos para as necessidades da Administração, responsável primária para estabelecer, monitorar, avaliar e reportar sobre o controle interno. Surgeriu, também, que os critérios deveriam ser desenvolvidos através de um processo que resultaria na sua aceitação por outros grupos interessados, incluindo auditores internos e independentes, educadores e orgãos reguladores.

Com base nessas recomendações, as referidas entidades patrocinadoras formaram o COSO - Committee of Sponsoring Organizations of the Treadway Commission, que elaborou minucioso estudo publicado em 1992, sob o título "Internal Control - Integrated Framework".

Este sumário sobre os antecedentes que justificaram a elaboração de um trabalho tão abrangente sobre a questão do controle interno foi incorporado a este trabalho, com o objetivo de realçar a real importância do estudo e avaliação do sistema de controle interno para o auditor contábil. Este estudo e avaliação, determinados pela segunda norma do trabalho de campo do auditor, invariavelmente vão além dos requisitos mínimos contidos na referida normas quer por solicitação da entidade auditada, quer por necessidade determinada pelas circunstâncias de cada auditoria, ou, ainda, por deliberação do próprio auditor, como forma de agregar valor à sua auditoria.

É nesta perspectiva, de agregar valor à auditoria, que vislumbramos o papel do auditor contábil nas auditorias de sistemas de garantia da qualidade, discutido no Capítulo 5, tendo o estudo e avaliação do controle interno como ponto comum, elo de ligação, no qual o sistema de gestão e garantia da qualidade, uma vez implementados tornam-se parte integrante. 


\subsection{2. $\quad O$ conceito de controle interno}

O conceito de controle interno mais difundido ao longo das últimas décadas é aquele publicado, em 1949, pelo AICPA - American Institute of Certified Public Accountants, em relatório especial intitulado Internal Control: Elements of a Coordinated System and its Importance to Management and Independent Public Accountant. O conceito apresentado neste relatório posteriormente incorporado ao SAS - Statement on Auditing Standards ํㅜ 1, do próprio AICPA, é o seguinte:

Controle interno compreende o plano da organização e todos os métodos coordenados e medidas adotadas dentro de uma organização para proteger seu ativo, verificar a exatidão e a fidedignidade de seus dados contábeis, incrementar a eficiência operacional e promover a obediência às diretrizes administrativas estabelecidas. Esta definição talvez seja mais ampla do que o significado às vezes atribuído ao termo. Reconhece que um 'sistema' de controle interno estende-se para além de assuntos diretamente relacionados com as funções dos departamentos de contabilidade e finanças 8 .

Trata-se de uma definição bastante abrangente, que contempla funções contábeis e administrativas, sem contudo, estabelecer limites entre elas.

Como o estudo e a avaliação do sistema de controle interno tornaram-se um procedimento relevante nas auditorias realizadas com o objetivo de expressar uma opinião sobre as demonstrações contábeis, o AICPA através do Comitê responsável pelos Padrões de Auditoria, publicou pronunciamento esclarecendo que o controle interno (sentido amplo) compreende controles que se podem caracterizar como contábeis ou como administrativos, tendo por base as seguintes definições: 
Controles contábeis compreendem o plano da organização e todos os métodos e procedimentos referentes e diretamente relacionados com a salvaguarda do ativo e a fidedignidade dos registros financeiros. Geralmente compreendem controles tais como os sistemas de autorização e aprovação, separação entre tarefas relativas à manutenção de registros e elaboração de relatórios e aqueles que dizem respeito à operação ou custódia do ativo, controles físicos sobre o ativo e auditoria interna. 9

Controles administrativos são os que compreendem o plano da organização e todos os métodos e procedimentos referentes principalmente à eficiência operacional e obediência às diretrizes administrativas e que normalmente se relacionam apenas indiretamente com os registros contábeis e financeiros. Em geral, incluem controles como análises estatísticas, estudo de tempo e movimento, relatório de desempenho, programas de treinamento de empregados, e controles de qualidade ${ }^{9}$.

Posteriormente, foi efetuada uma nova revisão das definições de controle contábil e controle administrativo. As definições revisadas são as seguintes:

Controle administrativo compreende, mas não se limita, ao plano de organização e aos procedimentos e registros ligados aos processos de decisão que levam à autorização das transações pela administração. 10

Controle contábil compreende o plano de organização e os procedimentos e registros envolvidos na proteção dos ativos e na confiabilidade dos registros financeiros, que se destinam a fornecer uma segurança razoável de que:

a) as transações são executadas de acordo com a autorização geral ou específica da administração;

b) as transações são registradas conforme necessário:

1- para permitir a preparação de demonstrações financeiras de conformidade com os princípios contábeis geralmente aceitos, ou qualquer outro critério aplicável a essas demonstrações e

2 - para manter a contabilização dos ativos. 
c) o acesso aos ativos só é permitido de acordo com a autorização da administração;

d) a contabilização dos ativos é comparada com os ativos existentes, a intervalos razoáveis, tomando-se as providências necessárias com respeito a quaisquer diferenças. 11

A evolução do conceito, ou melhor, do entendimento do que venha a ser controle interno não parou por aí. Conforme mencionado no item 4.6, supra, o COSO Committee of Sponsoring Organizations of the Treadway Commission elaborou minucioso estudo objetivando buscar um entendimento comum sobre o conceito de controle interno. Este estudo, publicado em 1992 com o título de "Internal Control - Integrated Framework" apresentou um núcleo para definição de controle interno do qual derivam outras definições com objetivos específicos. O núcleo da definição apresentada foi o seguinte:

Internal control is the process by which an entity's board of directors, management and/or other personnel obtain reasonable assurance as to achievement of specified objectives: it consists of nine interrelated components, with integrity, ethical values and competence, and the control environment, serving as the foundation for the other components, which are: establishing objectives, risk assessment, information systems, control procedures, communication, managing change, and monitoring, 12

A tradução livre dessa definição seria:

Controle interno é o processo através do qual o Conselho de Administração, a gerência e/ou outros funcionários obtêm razoável segurança do cumprimento dos objetivos especificados. Consiste de nove componentes inter-relacionados com integridade, valores éticos e competência e ambiente de controle, servindo de base para outros componentes quais sejam: estabelecer objetivos, avaliar riscos, 
sistemas de informação, procedimentos de controle, comunicação, gerenciamento de mudanças e monitoramento.

Os componentes $\mathbf{1 3}$ inter-relacionados são detalhados na figura 4.1. Componentes do controle interno. 


\section{FIGURA 4.1. - COMPONENTES DO CONTROLE INTERNO}

\begin{tabular}{|ll|}
\hline $\begin{array}{l}\text { Integridade, valores éticos e } \\
\text { competência }\end{array}$ & $\begin{array}{l}\text { Integridade e valores éticos são praticados em todos os níveis } \\
\text { da organização e as pessoas são competentes }\end{array}$ \\
Ambiente de controle & $\begin{array}{l}\text { Existe uma atmosfera que contribui para um controle efetivo e } \\
\text { uma consciência de controle por parte de seu pessoal }\end{array}$ \\
Avaliação de risco & $\begin{array}{l}\text { Os objetivos são estabelecidos para a empresa como um todo } \\
\text { e para as atividades significativas, e correspondentes } \\
\text { implementação de estratégias e planos são estabelecidos. }\end{array}$ \\
Sistema de Informação & $\begin{array}{l}\text { Os riscos relacionados ao cumprimento dos objetivos são } \\
\text { identificados e analisados. }\end{array}$ \\
Procedimentos de controle & $\begin{array}{l}\text { Informações necessárias são identificadas e sistemas são } \\
\text { colocados em funcionamento para fornecê-las. }\end{array}$ \\
Crocedimentos de controle estão funcionando para assegurar a \\
aderência às políticas e identificar riscos relacionados com o \\
cumprimento dos objetivos.
\end{tabular}

A definição apresentada parte da premissa de que controle interno e objetivos estão diretamente relacionados e, portanto, dois elementos são indispensáveis ao seu entendimento, quais sejam:

- a existência de objetivos que uma entidade procura alcançar; e

- a existência de ações tomadas com o propósito de cumprir estes objetivos. 
Objetivos podem ser macros, como, por exemplo; os objetivos de uma entidade como um todo, ou ser alvo de uma atividade específica dentro da entidade, por exemplo; fornecer informações financeiras confiáveis.

Com o objetivo de facilitar o enfoque de certos aspectos do controle interno, e também permitir a distinção entre o que pode ser esperado de um sistema de controle interno, o estudo elaborado pelo COSO resumiu os objetivos de uma entidade em três categorias: Operações, Relatórios financeiros e Cumprimento de leis e regulamentos.

Um sistema de controle interno deve fornecer razoável segurança de que certos objetivos - aqueles relativos aos relatórios financeiros e cumprimento de leis e regulamentos - estão sendo cumpridos. Estes objetivos são impostos por partes externas à entidade. Seu cumprimento depende de como as atividades dentro do controle da entidade são executadas. Os objetivos operacionais, porém, são baseados em decisões gerenciais, por exemplo, um determinado retorno sobre 0 investimento, participação de mercado, ou entrar em novas linhas de produtos. Seu cumprimento não está sempre dentro do controle da entidade. Para estes objetivos, o sistema de controle interno pode fornecer razoável segurança de que os objetivos serão cumpridos somente na extensão em que seu cumprimento estiver dentro do controle gerencial. Por outro lado, o sistema de controle interno pode e deve fornecer razoável segurança de que a gerência ciente da extensão para qual a entidade está se movimentando na direção de cumprir aqueles objetivos. ${ }^{14}$

Analisando a evolução do conceito de controle interno, tem-se a sensação de que é mais importante estabelecer limites que permitam distinguir áreas de atuação 
profissional, com o objetivo de imputar responsabilidades do que conceituá-lo, no sentido pleno do termo. Esta sensação fica mais evidente quando o referido estudo aborda a existência de perspectivas diferentes entre os usuários do sistema de controle interno. Exemplos:

\section{ALTA ADMINISTRAÇÃO}

O controle na visão da Alta administração considera a entidade como um todo. Suas responsabilidades são desenvolver os objetivos e as estratégias da entidade, e direcionar seus recursos materiais e humanos para cumprir esses objetivos. Abrange um largo espectro, incluindo políticas, procedimentos e ações para ajudar a assegurar que a empresa cumpriu seus objetivos. Inclui todas as atividades executadas pessoalmente ou delegadas que habilitam a Alta Gerência a: dirigir e monitorar as operações, estar alerta a eventos internos e externos relevantes, e identificar e negociar riscos.

O controle interno habilita a Alta administração a tomar ações em tempo hábil quando as condições mudam. A informação é fornecida, por exemplo: sobre produção, vendas, níveis de estoque, e outras áreas que conduzem a uma decisão eficaz. Grandes eventos, tais como; mudanças tecnológicas, inovações setoriais, ações dos concorrentes, clientes e fornecedores, e iniciativas legislativas também são informados. Isto permite à Alta Administração reduzir impactos adversos ou tirar vantagens de oportunidades emergentes. O controle interno também ajuda a Alta Administração a assegurar que está cumprindo suas responsabilidades legais, sociais e ambientais. Isto inclui regras para plano de benefícios a funcionários, regulamentos de segurança dos trabalhadores e regras 
para risco de perda na alienação de propriedades, assegurando proteção para a manutenção da reputação da empresa. 15

\section{AUDITORES INDEPENDENTES}

Como auditores das demonstrações contábeis, a perspectiva do controle interno está focalizada principalmente sobre os aspectos que suportam ou afetam as demonstrações contábeis externas das entidades.

Embora o auditor independente, para planejar sua auditoria, tenha de obter conhecimento sobre os negócios da entidade e do setor em que ela atua, incluindo seus objetivos de negócios, estratégias e posição competitiva, não há a necessidade de o auditor auditar a totalidade do controle interno para emitir uma opinião sobre as demonstrações contábeis. Esta limitação da abrangência é a mesma que muito outros devem fazer para executar suas funções. 15

A partir do núcleo de definição anteriormente citado derivou a seguinte definição de controle interno com o objetivo de assegurar a preparação de relatórios financeiros confiáveis:

Internal control over financial reporting is the process by which an entity's board of directors, management and/or other personnel obtain reasonable assurance as to the reliability of the reported financial results: it consists of nine interrelated components, with integrity, ethical values and competence, and the control environment, serving as the foundation for the other components, which are: establishing objectives, risk assessment, information 
systems, control procedures, communication, managing change, and monitoring, 16

A tradução livre dessa definição seria:

Controle interno sobre relatórios financeiros é um processo pelo qual o Conselho de Administração, a gerência e/ou outros funcionários obtêm razoável segurança da confiabilidade dos resultados financeiros reportados. Consiste de nove componentes inter-relacionados com integridade, valores éticos e competência e ambiente de controle, servindo de base para outros componentes, quais sejam estabelecer objetivos, avaliar riscos, sistema de informação, procedimentos de controle, comunicação, gerenciamento de mudanças e monitoramento.

Cabe ressaltar que o COSO foi muito feliz ao definir que controle interno é um processo, ou seja, é algo que capta dados, processa e devolve informações aos seus usuários, transmitindo a noção sistêmica (um sistema aberto) determinada pela necessidade de realimentação do processo. O controle interno compreende uma série de ações distribuídas ao longo de todas as atividades desenvolvidas por uma entidade. Estas ações variam em função de cada estilo gerencial; em outras palavras, da maneira que a alta administração conduz os negócios da entidade.

Para fins deste trabalho, utilizaremos o conceito de controle interno voltado aos relatórios financeiros, visto serem estes o objetivo principal do exame efetuado pelo auditor contábil. 


\subsection{3. $\quad 0$ controle interno e o sistema de gestão e garantia da qualidade}

Conforme discutido nos Capítulos anteriores, a questão da qualidade está diretamente ligada à maneira como as atividades são gerenciadas e controladas. Cada administrador tem sua fórmula e acaba por exercer impacto direto sobre a configuração dos sistemas. Assim, é essencial que estes sistemas sejam compatíveis e integrados.

Enquanto o sistema de controle interno está voltado para a entidade como um todo, o sistema de gestão e garantia da qualidade está especificamente voltado para o atendimento de questões da qualidade, tais como permitir o cumprimento das políticas e dos objetivos estabelecidos; fornecer a adequada confiança de que o sistema é bem entendido e eficaz, assegurar que os produtos e serviços efetivamente atendem às expectativas do cliente. privilegiando a prevenção, ao invés da detecção, isto é; identificando os problemas antes que eles ocorram.

É de se notar que, embora o sistema de gestão e garantia da qualidade tenha 0 objetivo específico mencionado no parágrafo anterior, ele acaba também envolvendo a entidade como um todo (veja ciclo da qualidade), a exemplo do sistema de controle interno. Contudo, como o sistema de controle interno é mais abrangente - não está voltado a uma questão específica - entendemos que o sistema de gestão e garantia da qualidade, uma vez implementado, passa a integrar o sistema de controle interno sendo, portanto, dentro da visão sistêmica que se coloca neste trabalho, um subsistema do sistema de controle interno. 
Neste sentido, o controle interno não só está integrado com a questão da qualidade, como também é crítico para seu sucesso 17.

\subsection{4. $\quad 0$ ciclo do controle interno contábil}

O ciclo do controle interno contábil compreende todas as operações/transações realizadas por uma entidade, desde a identificação inicial, passando pelo processamento, até à preparação de informações e relatórios financeiros confiáveis, envolvendo, portanto, a estrutura organizacional como um todo.

O ciclo do controle interno contábil pode variar dependendo do tipo de atividade desenvolvida por uma entidade e, geralmente, pode incluir as seguintes fases e atividades: ciclo de vendas, faturamento de despacho do produto, contas a receber e recebimento; estoque e custo das vendas; compras, recebimento de mercadorias, contas a pagar e pagamentos.

\subsubsection{Ciclo de vendas, faturamento e despacho do produto, contas a receber e recebimentos}

O ciclo que tem início com a venda de um produto ou serviço e termina com o recebimento é o mais importante dentro de uma entidade. Geralmente, inicia com a emissão de um pedido de vendas, que pode ser feito diretamente pelo cliente ou pelo representante comercial da entidade. Este pedido desencadeia uma série de atividades que passam a ser controladas pelo sistema de controle interno contábil, tais como; análise de crédito, disponibilidade de estoque, prazo para entrega, 
emissão de faturamento, estatísticas de vendas, despacho do produto ou prestação do serviço, contas a receber, recebimento, fluxo de caixa, etc.

A execução e o controle destas atividades envolvem parte substancial das operações de uma entidade e, portanto, devem ser devidamente identificadas, classificadas, registradas, sumarizadas e reportadas aos diversos usuários dessas informações. Para que isto seja possível, o sistema de controle interno contábil deve ser cuidadosamente estruturado, para que nenhum usuário fique privado de informações relevantes.

\subsubsection{Ciclo de estoque e custo das vendas.}

O ciclo de estoque inicia com o recebimento dos insumos necessários ao processo de produção e termina com a entrega do produto ao cliente. Trata-se do ciclo interno da entidade, pois seu início, geralmente, depende do recebimento dos insumos obtidos através do ciclo de compras/pagamentos que veremos a seguir, e seu término depende da entrega do produto ao cliente, feita através do ciclo de vendas/recebimentos.

Além de todas as atividades relacionadas ao processo de produção, inclusive realização de inventário físico, armazenamento etc. o ciclo de estoque e custo das vendas é particularmente importante porque é através dele que os custos de produção são identificados, classificados, acumulados, sumarizados e reportados aos seus usuários. Para produzir informações tão relevantes, torna-se necessário o desenvolvimento de um sistema de acumulação de custos igualmente integrado ao sistema de controle interno contábil. 


\subsubsection{Ciclo de compras, recebimento de mercadorias, contas a pagar e pagamentos}

O ciclo de compras inicia com uma requisição ou pedido de compra, os quais podem ser gerados em qualquer setor de uma entidade, e termina com 0 pagamento do item adquirido, que pode ser um insumo para o processo de produção, um material de consumo, um serviço prestado, uma despesa com propaganda, um equipamento etc. As atividades contidas no ciclo de compras/pagamentos envolvem todas as operações de uma entidade que de alguma forma geram pagamentos. Algumas dessas atividades são: cotação de preços, cadastro de fornecedores, estatísticas de compras, recebimento de insumos, escrituração de livros fiscais, emissão de cheques, fluxo de caixa, etc.

\subsubsection{Pontos de controle interno contábil}

Segundo Gil, $\mathbf{1 8}$ ponto de controle é a situação caracterizada pelo auditor como de interesse para validação e avaliação. É através da identificação dos pontos de controle que auditor direciona seus testes com o objetivo de validá-lo e avaliá-lo.

O ponto de controle deve ser cuidadosamente analisado, pois resulta da sua validação e avaliação a confiança que o auditor deposita no sistema de controle interno como um todo e a extensão dos demais procedimentos de auditoria aplicáveis em cada circunstância.

O ponto de controle é, portanto, a unidade básica (mínima) dentro do sistema de controle interno e os parâmetros para uma análise podem estar relacionados à 
salvaguarda dos ativos, à segregação de funções ou à identificação de um erro, falha, ou omissão.

Vale ressaltar que não é objetivo do auditor contábil a identificação de fraudes, desvios ou irregularidades, embora isto possa ocorrer como resultado da aplicação dos procedimentos de auditoria como um todo.

Os pontos de controle podem ser classificados nos seguintes principais grupos:

a) Reconciliações e comparação dos ativos com os registros contábeis

O objetivo de comparar os ativos com os registros contábeis é determinar se os ativos existentes conferem com os registros contábeis. Para o auditor contábil, a reconciliação dos registros contábeis e comparação com os ativos existentes representam um forte ponto de controle interno contábil porque assegura a fidedignidade dos registros contábeis e, por conseqüência, das demonstrações contábeis e evidenciam o procedimento de conferência dos ativos existentes, independentemente do controle mantido pelo seu custodiante. Alguns exemplos deste pontos de controle são: contagens de caixa, contagem de valores mobiliários, conciliações bancárias, inventário físico dos estoques e dos bens integrantes do ativo imobilizado.

Existem, também, as reconciliações entre registros independentes. Exemplos: quantidade de produtos despachado é reconciliada com a quantidade de produtos faturados; o saldo das contas de estoque (matériaprima, produtos em processo e produtos acabados) é reconciliado com os 
relatórios de custos; o saldo das contas a receber do razão geral é reconciliado com os saldos do razão auxiliar das contas a receber.

b) Revisão das saídas

As revisões de saída devem ser feitas por pessoa com experiência e conhecimento suficientes para identificar erros. Geralmente, estas revisões têm o propósito de avaliar a validade e acurácia de uma transação ou um grupo de transações, tendo como parâmetro os resultados esperados. Estes parâmetros podem estar consubstanciados numa peça orçamentária ou num relatório de exceções.

Alguns exemplos de revisão de saídas são: compras registradas contra valores orçados, vendas registradas comparadas com as expectativas do gerente responsável por estas vendas, provisões para obsolescência e desvalorização dos estoques são revisadas pela gerência responsável, com base no histórico e nas projeções efetuadas.

c) Controle de acesso

Um dos objetivos do sistema de controle interno é a salvaguarda dos ativos. Neste sentido, o acesso a estes ativos deve ser restrito, tendo como objetivo obter segurança razoável de que transações não autorizadas venham a ocorrer.

O SAS ํo 119 apresenta três significados possíveis para o termo 'salvaguarda'. O primeiro foi extraído do dicionário Webster: "um meio de 
proteção contra algo indesejável"; o segundo refere-se apenas à proteção contra perda, proveniente de erros intencionais ou não, na realização de transações e no controle dos ativos correspondentes; e o terceiro diz respeito tão-somente à proteção contra perdas de erros intencionais que incluem: fraude e falsificação dos registros.

Alguns exemplos de controle de acesso são: controle físico sobre faturas, controle físico sobre avisos de crédito em branco, área de produção com acesso restrito a pessoal autorizado, estoques armazenados em locais com acesso controlado, controle sobre acesso ao sistema de compras, talões de cheques são mantidos em locais de acesso restrito às pessoas autorizadas.

d) Autorização e aprovação

Autorização e aprovação são tipos de controle que visam a restringir o acesso aos ativos e são implementados para prevenir que transações não válidas ou não apropriadas venham a ocorrer 20 . Um exemplo deste tipo de controle seria assegurar que um pagamento seja efetuado somente quando a autorização para fazê-lo tenha sido recebida.

Alguns outros exemplos são: aprovação do crédito de venda, notas de crédito aprovadas independentemente, aprovação das baixas de estoque, aprovação de baixa do contas a receber, pedidos de compras emitidos somente por pessoas autorizadas, apenas pessoas autorizadas podem emitir requisição de pagamentos. 
e) Revisão de alterações em transações e arquivos-mestre

A revisão de alterações em transações e arquivos-mestre é aquela voltada para o detalhe operacional do dia-a-dia e tem como objetivo básico evitar que alterações não autorizadas nas transações e arquivos-mestre venham a ocorrer e não deixem de ser detectadas.

Alguns exemplos deste tipo de controle são: conferir notas fiscais de vendas com documentos-suporte, confrontar comprovante de entrega do produto vendido com a nota fiscal e pedido de venda, conferir cálculos e somas das notas fiscais de venda, notas de crédito etc., conferir preço constante da nota fiscal com tabela de preços, conferir descontos concedidos com política de vendas.

f) Segregação de funções

Em geral, os sistemas de controle interno são desenhados para evitar o acúmulo de funções incompatíveis por uma única pessoa. Funções incompatíveis sob a ótica de controle interno, são aquelas que colocam qualquer pessoa em posição de perpetrar e esconder erros ou irregularidades no curso normal de suas atividade 21 . Qualquer pessoa que registre uma transação e concomitantemente tenha acesso aos ativos, normalmente está em condição de ocultar definitivamente erros ou irregularidade.

Alguns exemplos de funções incompatíveis: a pessoa que registra os cheques não pode ter acesso às conciliações bancárias, a pessoa que 
vende não pode aprovar o crédito, a pessoa que controla a cobrança não pode ter acesso aos registros contábeis, a pessoa que custodia os estoques não pode ter acesso aos registros contábeis.

Os pontos de controle discutidos acima podem ser programados - executados através de sistema eletrônico de dados - ou manuais - executados por pessoas autorizadas. É claro que alguns deles, como, por exemplo, as revisões de saídas devem, preferencialmente, ser executados manualmente, em função de requererem a análise crítica, o conhecimento e a experiência de um profissional, o que nem sempre pode ser programado num sistema eletrônico de dados. Em contrapartida, há outros que preferivelmente devem ser programados, como por exemplo, as revisões de alterações em transações e arquivos-mestre. 


\section{NOTAS}

1 Carvalho, Luiz Nelson Guedes - Parecer dos Auditores Independentes sobre Demonstrações Contábeis no Brasil: Estudo das limitações ao seu poder de comunicação, Dissertação de Mestrado FEA - USP, 1989. pp 24 a 27.

2 The Institute of Chartered Accountants in England and Wales - Auditing and Reporting 1993/94, the full texts of all UK auditing standards and guidelines, all UK auditing exposure drafts other statements on auditing extant at April 1993 - London, 1993, p. 11.

3 The American Accounting Association (AAA) - A Statement of Basic Auditing Concepts-- N.York, 1973, p. 2.

4 International Federation of Accountants - IFAC - IFAC Handbook 1992 Technical Pronouncements, New York, 1992, p. 101.

5 Sullivan, Lerry D., Gnospelius, Richard A., Defliese, Philip L. and Jaenicke, Henry R. - Montegomery's Auditing - Tenth Edition, A Ronald Press Publication - John Wiley \& Sons, New York, 1985, p. 5.

6 American Institute of Certified Public Accountants - AICPA - Exposição de Normas de Auditoria no 1 Tradução - Equipe da Price Waterhouse Auditores Independentes - São Paulo, Editado pelo Instituto dos Auditores Independentes do Brasil, 1977, p.1 - \#110.01. 
7 American Institute of Certified Public Accountants - AICPA - Exposição de Normas de Auditoria no 1 Tradução - Equipe da Price Waterhouse Auditores Independentes - São Paulo, Editado pelo Instituto dos Auditores Independentes do Brasil, 1977, p. 1 - \#110.02.

8 American Institute of Certified Public Accountants - AICPA - Exposição de Normas de Auditoria no 1 Tradução - Equipe da Price Waterhouse Auditores Independentes - São Paulo, Editado pelo Instituto dos Auditores Independentes do Brasil, 1977, p. 1 - \# 320.09

9 American Institute of Certified Public Accountants - AICPA - Exposição de Normas de Auditoria no 1 Tradução - Equipe da Price Waterhouse Auditores Independentes - São Paulo, Editado pelo Instituto dos Auditores Independentes do Brasil, 1977, p.1 - \# 320.10.

10 American Institute of Certified Public Accountants - AICPA - Exposição de Normas de Auditoria no 1 Tradução - Equipe da Price Waterhouse Auditores Independentes - São Paulo, Editado pelo Instituto dos Auditores Independentes do Brasil, 1977, p. 1 - \# 320.27.

11 American Institute of Certified Public Accountants - AICPA - Exposição de Normas de Auditoria no 1 Tradução - Equipe da Price Waterhouse Auditores Independentes - São Paulo, Editado pelo Instituto dos Auditores Independentes do Brasil, 1977, p. 1 - \# 320.28. 
12 The Committee of Sponsoring Organizations of the Treadway Commission - Internal control: Integrated framework - Exposure Draft March 12, 1991; New York, 1991. p. 51.

13 The Committee of Sponsoring Organizations of the Treadway Commission - Internal control: Integrated framework - Exposure Draft March 12, 1991; New York, 1991. p. 56.

14 The Committee of Sponsoring Organizations of the Treadway Commission - Internal control: Integrated framework - Exposure Draft March 12, 1991; New York, 1991. p. 51.

15 The Committee of Sponsoring Organizations of the Treadway Commission - Internal control: Integrated framework - Exposure Draft March 12, 1991; New York, 1991. página 48 e 49.

16 The Committee of Sponsoring Organizations of the Treadway Commission - Internal control: Integrated framework - Exposure Draft March 12, 1991; New York, 1991. p. 52 e 53.

17 The Committee of Sponsoring Organizations of the Treadway Commission - Internal control: Integrated framework - Exposure Draft March 12, 1991; New York, 1991. p. 55.

18 Gil, Antonio de Loureiro - Auditoria de Computadores - São Paulo. Atlas, 1989, p. 46. 
19 American Institute of Certified Public Accountants - AICPA - Exposição de Normas de Auditoria no 1 Tradução - Equipe da Price Waterhouse Auditores Independentes - São Paulo, Editado pelo Instituto dos Auditores Independentes do Brasil, 1977, p. 1 - \# 320.14-16.

20 Deloitte Touche Tohmatsu International - Internal control - New York, 1993, p. 30.

21 American Institute of Certified Public Accountants - AICPA - Exposição de Normas de Auditoria no 1 Tradução - Equipe da Price Waterhouse Auditores Independentes - São Paulo, Editado pelo Instituto dos Auditores Independentes do Brasil, 1977, p. 17 - \# 320.36. 


\section{O PAPEL DO AUDTLOR CONLABIL NA AUDTLRIA \\ DE SISTEMAS DE GARANUAA DAR QUALIDADE}

O papel que o auditor contábil pode desempenhar na auditoria de sistemas de garantia da qualidade necessita ser estudado por algumas das seguintes razões:

- As funções do auditor contábil vem se expandindo ao longo das últimas décadas, tendo como alvo a gestão empresarial, e a auditoria de sistemas de gestão e garantia da qualidade é apenas mais uma dessas metas;

- A contribuição que este profissional pode trazer às auditorias de sistemas de gestão e garantia da qualidade não tem merecido a atenção dos empresários, dos próprios profissionais da área contábil, dos gestores dos programas de qualidade, dos educadores e dos pesquisadores;

- A identificação de caminhos possíveis para a participação do auditor contábil nas auditorias de sistema de garantia da qualidade deve contribuir para a definição da maneira como esta possível participação poderá ser efetivada;

- O desenvolvimento de programas de treinamento necessários à capacitação do auditor contábil nas questões da qualidade; 
- O profundo conhecimento que estes profissionais têm das técnicas de auditoria está sendo sub-utilizado, ou melhor, não vem sendo utilizado no processo de auditoria de sistemas de garantia da qualidade.

O auditor contábil possui uma estatura profissional que o credencia a capitalizar a oportunidade de participar ativamente das auditorias de sistemas de garantia da qualidade e, assim, expandir sua área de atuação profissional, o que, aliás, tem sido feito ao longo das últimas décadas.

\subsection{As responsabilidade do auditor contábil na auditoria de sistemas de garantia da qualidade}

As responsabilidades atribuíveis ao auditor contábil não devem diferir daquelas atribuídas ao auditor da qualidade e que estão claramente definidas no documento NBR ISO 10.011-1 item 4.2.1.2. e 4.2.1.3, objeto de comentário no item 3.5 2. deste trabalho.

Entretanto, para que possa assumir este nível de responsabilidade o auditor contábil deve se qualificar conforme previsto na NBR ISO 10.011-2, ou seja, perante uma Banca selecionada pelo organismo de gestão de um esquema de certificação de âmbito nacional ou equivalente.

Para conseguir este credenciamento, um dos requisitos consiste em que o candidato tenha um mínimo de quatro anos de experiência profissional na área, em regime de tempo integral, dos quais pelo menos dois devem ter sido em atividades relativas à garantia da qualidade. 
Nota-se que as exigências são muito rigorosas e o caminho a ser percorrido, um tanto quanto longo, o que é extremamente positivo. Contudo, não há como negar que este fator é uma limitação à plena participação do auditor contábil nas auditorias de sistemas de garantia da qualidade.

Desta forma, a responsabilidade que o auditor contábil poderia assumir perante seu cliente, num primeiro momento, não estaria revestida das exigências e qualificações determinadas pelas diretrizes para auditoria de sistema da qualidade. Esta responsabilidade estaria diretamente relacionada ao grau de envolvimento do auditor contábil com as questões da qualidade e à forma como seus comentários (suas contribuições) seriam levados à alta administração. Em outras palavras, o conhecimento que o auditor contábil vier a adquirir sobre os sistemas de gestão e garantia da qualidade estará sempre limitado àquele adquirido por meio de seu exame.

\section{$5.2 \quad 0$ perfil do auditor contábil adequado à auditoria da qualidade}

Conforme discutido no item 3.1.2., a pessoa do auditor merece uma atenção especial, pois da sua qualificação e da maneira como seu trabalho é conduzido depende, basicamente, a eficácia de uma auditoria da qualidade.

\subsubsection{0 perfil do candidato a auditor da qualidade definido na norma ISO 10.011-2}

A norma ISO 10.011-2 define o seguinte perfil: 
- Educação

O auditor deve ter pelo menos o segundo grau completo.

- Treinamento

O auditor deve ser treinado até um nível que assegure sua competência nas habilidades necessárias para executar e gerenciar auditorias. As seguintes áreas devem ser consideradas:

a) conhecimento e compreensão das normas nas quais se baseia a execução das auditorias de sistemas da qualidade;

b) técnicas de análise de exame, questionários, avaliação e preparação de relatórios; e

c) habilidades adicionais necessárias na gestão de uma auditoria, tais como; planejamento, organização, comunicação e direção.

- Experiência

Os candidatos a auditor devem ter um mínimo de quatro anos de experiência profissional na área, em regime de tempo integral, dos quais pelo dois devem ter sido em atividades relativas à garantia da qualidade. Além disso, o candidato deve ter adquirido experiência de todo o processo de auditoria através da participação de no mínimo quatro auditorias. 
- Atributos pessoais

O candidato a auditor deve ter mentalidade aberta e madura, julgamentos dignos de confiança, capacidade analítica e tenacidade; deve ter habilidade para perceber situações de maneira realista, compreender operações complexas, assim como o papel das unidades individuais dentro da empresa como um todo.

- Capacidade gerencial

O candidato a auditor deve demonstrar seu conhecimento e capacidade de utilizar as habilidades gerenciais necessárias na execução de uma auditoria da qualidade.

- Manutenção da competência

O auditor deve manter sua competência, assegurando seus conhecimentos das normas e requisitos dos sistemas da qualidade; e que os procedimentos e métodos de auditoria estão atualizados

- Idioma

O auditor deve possuir fluência no idioma em que a auditoria é feita. 


\subsection{2 $\quad 0$ perfil do auditor da qualidade estabelecido pelos Orgãos Certificadores}

O estudo de caso relatado no item 3.7., propiciou um contato direto com os profissionais que estão atuando, pelos Orgãos Certificadores, nas auditorias da qualidade.

Além da necessidade de possuir os atributos pessoais e capacidade gerencial descritos na norma ISO, o perfil dos profissionais que atuam nestes Orgãos Certificadores apresenta as seguintes qualificações:

- Educação

Geralmente os profissionais possuem formação na área de engenharia.

- Treinamento

Estes profissionais, sem exceção, cumprem a carga de treinamento recomendada pela norma ISO e são periodicamente avaliados quanto à atualização de seus conhecimentos.

- Experiência

Geralmente, são ex-executivos de áreas técnicas tais como; produção, manutenção, controle de qualidade etc., na faixa etária de quarenta anos, com experiência em gestão de sistemas da qualidade em empresas privadas. 
- Idioma

Fluência no idioma inglês é requisito imprescindível. Além disso, fluência em outros idiomas, principalmente o espanhol, em função do processo de integração com os países signatários do MERCOSUL é desejável.

\subsubsection{O perfil do auditor contábil}

Atualmente, os profissionais que atuam na auditoria das demonstrações financeiras possuem o seguinte perfil:

- Educação

Geralmente os profissionais possuem formação na área contábil.

- Treinamento

Estes profissionais, sem exceção, cumprem carga rigorosíssima de treinamento sobre normas e procedimentos de auditoria e contabilidade; legislações tributária e societária; micro-informática; marketing; finanças, entre outros. Devem, portanto, ter seus conhecimentos constantemente atualizados.

- Experiência

Geralmente. são profissionais de carreira, isto é; iniciam suas atividades como estagiários ou trainees em empresas que prestam serviços de auditoria contábil, na faixa etária de vinte e cinco a trinta e cinco anos, com experiência 
em auditoria das demonstrações contábeis de empresas das mais diversas origens, dos mais diversos ramos de atividade e das mais diversas formas de estrutura organizacional, incluindo as empresas que praticam qualidade.

- Idioma

Fluência em idiomas é requisito imprescindível para um profissional que atua no meio empresarial. Como o inglês é a língua franca dos negócios, obter fluência neste idioma é vital para o auditor contábil desempenhar adequadamente suas atribuições. Mais recentemente, com o advento do MERCOSUL, a fluência no idioma espanhol passou a ter mais relevância.

\subsection{4 $\quad$ perfil do auditor contábil voltado à auditoria da qualidade}

Diante do exposto, para que o auditor contábil possa desempenhar adequadamente seu papel na auditoria de sistemas de garantia da qualidade as seguintes qualificações devem ser valorizadas:

- Educação

A formação na área contábil deverá ser suplementada por conhecimentos de engenharia de produção, conhecimentos mais aprofundados de estatística aplicada no controle dos processos, e conhecimentos dos conceitos da qualidade. 
- Treinamento

Além da carga de treinamento sobre normas e procedimentos de auditoria e contabilidade; legislações tributária e societária; utilização da microinformática; marketing, finanças, entre outros, o auditor contábil deverá ser rigorosamente treinado nas normas e procedimentos aplicados à auditoria da qualidade bem como nas normas de gestão da qualidade e de garantia da qualidade.

- Experiência

A experiência em auditoria das demonstrações contábeis deve ser suplementada com experiência em auditorias de sistemas de garantia da qualidade. Esta experiência poderá ser adquirida: internamente caso na empresa em que o auditor contábil atue, exista um sistema de gestão e de garantia da qualidade implementado em suas operações; e externamente, com as empresas que praticam qualidade.

- Idioma

Fluência em idiomas é requisito imprescindível para auditor contábil voltado à auditoria da qualidade. Como o inglês é a língua franca dos negócios, obter fluência neste idioma é vital para que o auditor contábil possa desempenhar adequadamente seu papel na auditoria de sistemas de garantia da qualidade. Com o advento do MERCOSUL e a obrigatoriedade, imposta pela norma ISO, de fluência no idioma em que a auditoria da qualidade for realizada, a fluência no idioma espanhol tornou-se necessária. 


\subsubsection{Algumas considerações}

Encontrar profissionais com este perfil não será tarefa fácil. Nossa vivência no ramo de auditoria contábil permite-nos afirmar que profissionais com este perfil precisam ser formados; não estão disponíveis no mercado.

Como o processo de formação de um profissional com esta envergadura é bastante lento, a alternativa que se apresenta é a utilização de equipes de auditoria multidisciplinar, isto é; as qualificações necessárias, para o desempenho adequado do papel do auditor contábil na auditoria de sistemas de garantia da qualidade, estariam distribuídas entre os profissionais integrantes da equipe de auditoria.

\subsection{O ciclo da qualidade e o ciclo contábil}

Conforme mencionado nos Capítulos anteriores, o elo de ligação que aproxima o auditor contábil da auditoria da qualidade é o sistema de controle interno. A existência de uma integração entre ambos, aliada a outras técnicas de administração que otimizam o processo de produção na busca do controle da qualidade total, tais como; Just in time, Total quality control, Kanban, não discutidas neste trabalho, formam um poderoso instrumento gerencial capaz de prover aos cliente produtos e serviços com qualidade assegurada e aos usuários das informações contábeis informações e relatórios financeiros confiáveis. 
A figura 5.1. apresenta a matriz que correlaciona os requisitos de um sistema de garantia da qualidade de acordo com a norma ISO 9001, o ciclo de controle interno contábil, através de alguns pontos de controle, evidenciando a integração dos sistemas e indicando um caminho para o auditor contábil fornecer sua contribuição profissional à auditoria da qualidade. As letras (A), (M) e (B), colocadas após a descrição de cada ponto de controle interno, classificam o grau de correlação entre estes pontos de controle e o ciclo da qualidade em (A) Alta, (M) Média e (B) Baixa correlação. 
FIGURA 5.1. - MATRIZ DE CORRELAÇÃO ENTRE O CICLO DA QUALIDADE E

OS PONTOS DE CONTROLE INTERNO CONTÁBIL

\begin{tabular}{|c|c|c|c|c|}
\hline \multicolumn{2}{|c|}{ CICLO DA QUALIDADE } & \multicolumn{3}{|c|}{ PONTOS DE CONTROLE INTERNO CONTÁBIL } \\
\hline REQUISITOS & INTERPRETAÇÃO & $\begin{array}{l}\text { CICLO DE VENDAS, } \\
\text { FATURAMENTO E DESPACHO } \\
\text { DO PRODUTO, CONTAS A } \\
\text { RECEBER E RECEBIMENTOS } \\
\end{array}$ & $\begin{array}{l}\text { CICLO DE ESTOQUES E } \\
\text { CUSTO DAS VENDAS }\end{array}$ & $\begin{array}{l}\text { CICLO DE COMPRAS, } \\
\text { RECEBIMENTO DE } \\
\text { MERCADORIAS, CONTAS A } \\
\text { PAGAR E PAGAMENTOS }\end{array}$ \\
\hline $\begin{array}{l}\text { Responsabilidade da } \\
\text { Administração }\end{array}$ & $\begin{array}{l}\text { A Alta administração é } \\
\text { responsável pelo sistema } \\
\text { de garantia da qualidade. }\end{array}$ & $\begin{array}{l}\text { Os pedidos de venda são } \\
\text { aprovados por pessoa autorizada } \\
\text { (B) }\end{array}$ & $\begin{array}{l}\text { Qualquer alteração no } \\
\text { sistema de custeio é } \\
\text { aprovada por pessoa } \\
\text { autorizada (B) }\end{array}$ & $\begin{array}{l}\text { A aprovação de novos } \\
\text { fornecedores é feita por pessoa } \\
\text { autorizada (B) }\end{array}$ \\
\hline Sistemas da qualidade & $\begin{array}{l}\text { Traduz os princípios do } \\
\text { sistema de qualidade em } \\
\text { atividades. }\end{array}$ & $\begin{array}{l}\text { As políticas de venda e os } \\
\text { procedimentos operacionais } \\
\text { estão contidos no Manual de } \\
\text { Normas e Procedimentos (A) }\end{array}$ & $\begin{array}{l}\text { As políticas de estoque, o } \\
\text { sistema de produção e de } \\
\text { custeio e os procedimentos } \\
\text { operacionais estão contidos } \\
\text { no Manual de Normas e } \\
\text { Procedimentos (A) }\end{array}$ & $\begin{array}{l}\text { As políticas de compra e os } \\
\text { procedimentos operacionais } \\
\text { estão contidos no Manual de } \\
\text { Normas e Procedimentos (A) }\end{array}$ \\
\hline $\begin{array}{l}\text { Análise crítica do } \\
\text { contrato }\end{array}$ & $\begin{array}{l}\text { Busca assegurar que os } \\
\text { requisitos estão } \\
\text { adequadamente definidos } \\
\text { e documentados, que as } \\
\text { divergências estão } \\
\text { acordadas e que a } \\
\text { entidade tem capacidade } \\
\text { de atender os requisitos } \\
\text { contratuais. }\end{array}$ & & & $\begin{array}{l}\text { Ordens de compra são emitidas } \\
\text { apenas por pessoas autorizadas } \\
\text { (A) }\end{array}$ \\
\hline
\end{tabular}




\begin{tabular}{|c|c|c|c|c|}
\hline \multicolumn{2}{|c|}{ CICLO DA QUALIDADE } & \multicolumn{3}{|c|}{ PONTOS DE CONTROLE INTERNO CONTÁBIL } \\
\hline REQUISITOS & INTERPRETAÇÃO & $\begin{array}{l}\text { CICLO DE VENDAS, } \\
\text { FATURAMENTO E DESPACHO } \\
\text { DO PRODUTO, CONTAS A } \\
\text { RECEBER E RECEBIMENTOS }\end{array}$ & $\begin{array}{l}\text { CICLO DE ESTOQUES E } \\
\text { CUSTO DAS VENDAS }\end{array}$ & $\begin{array}{l}\text { CICLO DE COMPRAS, } \\
\text { RECEBIMENTO DE } \\
\text { MERCADORIAS, CONTAS A } \\
\text { PAGAR E PAGAMENTOS }\end{array}$ \\
\hline Controle do projeto & $\begin{array}{l}\text { Assegurar que os } \\
\text { requisitos específicos } \\
\text { sejam alcançados. }\end{array}$ & & & $\begin{array}{l}\text { Controle de acesso aos projetos. } \\
\text { Somente pessoas autorizadas } \\
\text { aprovam gastos com os projetos } \\
\text { (A) }\end{array}$ \\
\hline $\begin{array}{l}\text { Controle de } \\
\text { documentos }\end{array}$ & $\begin{array}{l}\text { Assegurar que } \\
\text { documentação adequada } \\
\text { e atualizada esteja } \\
\text { disponível ao longo do } \\
\text { sistema. }\end{array}$ & $\begin{array}{l}\text { Controle sobre formulários de } \\
\text { pedidos de vendas em branco. } \\
\text { Controle sobre faturas, notas } \\
\text { fiscais, avisos de crédito e } \\
\text { duplicatas (A) }\end{array}$ & $\begin{array}{l}\text { Controle sobre requisições } \\
\text { de matérias primas e } \\
\text { Ordens de fabricação (A) }\end{array}$ & $\begin{array}{l}\text { Controle sobre formulários de } \\
\text { pedidos de compra em branco. } \\
\text { Controle sobre cheques em } \\
\text { branco (A) }\end{array}$ \\
\hline Aquisição & $\begin{array}{l}\text { Assegurar que os produtos } \\
\text { ou serviços adquiridos } \\
\text { estão em conformidade } \\
\text { com os requisitos } \\
\text { especificados. }\end{array}$ & & & $\begin{array}{l}\text { Aprovação do pedido de compra } \\
\text { (A) }\end{array}$ \\
\hline $\begin{array}{l}\text { Produto fornecido pelo } \\
\text { comprador }\end{array}$ & $\begin{array}{l}\text { Estabelecer e manter um } \\
\text { procedimento para } \\
\text { verificação, armazenagem } \\
\text { e manutenção desses } \\
\text { produtos e ou serviços. }\end{array}$ & & $\begin{array}{l}\text { As mercadorias de } \\
\text { propriedade de terceiros em } \\
\text { poder da entidade são } \\
\text { identificadas (A) }\end{array}$ & \\
\hline
\end{tabular}




\begin{tabular}{|c|c|c|c|c|}
\hline \multicolumn{2}{|c|}{ CICLO DA QUALIDADE } & \multicolumn{3}{|c|}{ PONTOS DE CONTROLE INTERNO CONTÁBIL } \\
\hline REQUISITOS & INTERPRETAÇÃO & $\begin{array}{l}\text { CICLO DE VENDAS, } \\
\text { FATURAMENTO E DESPACHO } \\
\text { DO PRODUTO, CONTAS A } \\
\text { RECEBER E RECEBIMENTOS }\end{array}$ & $\begin{array}{l}\text { CICLO DE ESTOQUES E } \\
\text { CUSTO DAS VENDAS }\end{array}$ & $\begin{array}{l}\text { CICLO DE COMPRAS, } \\
\text { RECEBIMENTO DE } \\
\text { MERCADORIAS, CONTAS A } \\
\text { PAGAR E PAGAMENTOS }\end{array}$ \\
\hline $\begin{array}{l}\text { Identificação e } \\
\text { Rastreabilidade } \\
\text { do Produto }\end{array}$ & $\begin{array}{l}\text { Os produtos e serviços } \\
\text { devem ser identificáveis } \\
\text { em qualquer estágio do } \\
\text { projeto. }\end{array}$ & $\begin{array}{l}\text { O produto é confrontado com a } \\
\text { nota fiscal de venda antes do } \\
\text { despacho (B) }\end{array}$ & $\begin{array}{l}\text { Realização de inventário } \\
\text { físico periódico (B) }\end{array}$ & \\
\hline Controle do processo & $\begin{array}{l}\text { Assegurar que entradas, } \\
\text { processamento e saídas } \\
\text { da produção são } \\
\text { adequadamente } \\
\text { controladas. }\end{array}$ & & $\begin{array}{l}\text { Os ajustes resultantes da } \\
\text { compilação do inventário } \\
\text { físico são investigados (A) }\end{array}$ & \\
\hline Inspeção e ensaios & $\begin{array}{l}\text { Garantir que os materiais } \\
\text { adquiridos somente são } \\
\text { utilizados se estiverem de } \\
\text { acordo com os requisitos } \\
\text { especificados. }\end{array}$ & $\begin{array}{l}\text { O produto é confrontado com a } \\
\text { nota fiscal de venda antes do } \\
\text { despacho }(M)\end{array}$ & $\begin{array}{l}\text { Baixas de estoque são } \\
\text { aprovadas por pessoa } \\
\text { autorizada (M) }\end{array}$ & $\begin{array}{l}\text { A quantidade recebida é } \\
\text { comparada com a nota de } \\
\text { entrada e o pedido de compra (M) }\end{array}$ \\
\hline $\begin{array}{l}\text { Equipamento de } \\
\text { inspeção, medição e } \\
\text { ensaios }\end{array}$ & $\begin{array}{l}\text { Garantir que os } \\
\text { equipamentos e } \\
\text { dispositivos utilizados no } \\
\text { procedimento de inspeção, } \\
\text { medição e ensaios são } \\
\text { controlados. }\end{array}$ & & $\begin{array}{l}\text { Realização do inventário } \\
\text { físico periódico (B) }\end{array}$ & $\begin{array}{l}\text { Inventário físico periódico de } \\
\text { máquinas, equipamentos e outros } \\
\text { bens são realizados e os } \\
\text { resultados são confrontados com } \\
\text { os registros contábeis (B) }\end{array}$ \\
\hline
\end{tabular}




\begin{tabular}{|c|c|c|c|c|}
\hline \multicolumn{2}{|c|}{ CICLO DA QUALIDADE } & \multicolumn{3}{|c|}{ PONTOS DE CONTROLE INTERNO CONTÁBIL } \\
\hline REQUISITOS & INTERPRETAÇÃO & $\begin{array}{l}\text { CICLO DE VENDAS, } \\
\text { FATURAMENTO E DESPACHO } \\
\text { DO PRODUTO, CONTAS A } \\
\text { RECEBER E RECEBIMENTOS } \\
\end{array}$ & $\begin{array}{l}\text { CICLO DE ESTOQUES E } \\
\text { CUSTO DAS VENDAS }\end{array}$ & $\begin{array}{l}\text { CICLO DE COMPRAS, } \\
\text { RECEBIMENTO DE } \\
\text { MERCADORIAS, CONTAS A } \\
\text { PAGAR E PAGAMENTOS }\end{array}$ \\
\hline $\begin{array}{l}\text { Situação de inspeção e } \\
\text { ensaios }\end{array}$ & $\begin{array}{l}\text { Assegurar que somente } \\
\text { produtos aprovados sejam } \\
\text { despachados, usados ou } \\
\text { instalados. }\end{array}$ & & $\begin{array}{l}\text { A qualidade do produto é } \\
\text { controlada e aprovada }(A)\end{array}$ & $\begin{array}{l}\text { A qualidade da mercadoria é } \\
\text { controlada e aprovada }(A)\end{array}$ \\
\hline $\begin{array}{l}\text { Controle de produto } \\
\text { não conforme }\end{array}$ & $\begin{array}{l}\text { Evitar que produtos não } \\
\text { conformes sejam } \\
\text { indevidamente ou } \\
\text { inadvertidamente } \\
\text { despachados, usados ou } \\
\text { instalados. }\end{array}$ & $\begin{array}{l}\text { As devoluções de vendas são } \\
\text { analisadas para identificar suas } \\
\text { causas (A) }\end{array}$ & $\begin{array}{l}\text { Os produtos com defeito, } \\
\text { obsoletos e com baixa } \\
\text { movimentação são } \\
\text { identificados, segregados e } \\
\text { investigados }(A)\end{array}$ & $\begin{array}{l}\text { As devoluções de compras são } \\
\text { analisadas para identificar suas } \\
\text { causas (A) }\end{array}$ \\
\hline Ação corretiva & $\begin{array}{l}\text { Identificar as causas } \\
\text { primárias da não- } \\
\text { conformidade e tomar } \\
\text { medidas corretivas. }\end{array}$ & $\begin{array}{l}\text { As devoluções de vendas são } \\
\text { aprovadas por pessoa autorizada } \\
\text { (M) }\end{array}$ & $\begin{array}{l}\text { As baixas de estoque e os } \\
\text { ajustes de inventário são } \\
\text { aprovados por pessoa } \\
\text { autorizada (M) }\end{array}$ & $\begin{array}{l}\text { As devoluções de compras são } \\
\text { aprovadas por pessoa autorizada } \\
\text { (M) }\end{array}$ \\
\hline $\begin{array}{l}\text { Manuseio, } \\
\text { armazenamento, } \\
\text { embalagem e } \\
\text { expedição }\end{array}$ & $\begin{array}{l}\text { Preservar e manter a } \\
\text { qualidade dos materiais } \\
\text { recebidos. }\end{array}$ & & $\begin{array}{l}\text { O produto é armazenado em } \\
\text { local apropriado }(A)\end{array}$ & \\
\hline Registros da qualidade & $\begin{array}{l}\text { Manter registros legíveis, } \\
\text { identificáveis em relação } \\
\text { aos produtos envolvidos. }\end{array}$ & $\begin{array}{l}\text { As transações são identificadas, } \\
\text { coletadas, classificadas, } \\
\text { acumuladas, registradas e } \\
\text { reportadas (A) }\end{array}$ & $\begin{array}{l}\text { As transações são } \\
\text { identificadas, coletadas, } \\
\text { classificadas, acumuladas, } \\
\text { registradas e reportadas (A) }\end{array}$ & $\begin{array}{l}\text { As transações são identificadas, } \\
\text { coletadas, classificadas, } \\
\text { acumuladas, registradas e } \\
\text { reportadas (A) }\end{array}$ \\
\hline
\end{tabular}




\begin{tabular}{|c|c|c|c|c|}
\hline \multicolumn{2}{|c|}{ CICLO DA QUALIDADE } & \multicolumn{3}{|c|}{ PONTOS DE CONTROLE INTERNO CONTÁBIL } \\
\hline REQUISITOS & INTERPRETAÇÃO & $\begin{array}{l}\text { CICLO DE VENDAS, } \\
\text { FATURAMENTO E DESPACHO } \\
\text { DO PRODUTO, CONTAS A } \\
\text { RECEBER E RECEBIMENTOS }\end{array}$ & $\begin{array}{l}\text { CICLO DE ESTOQUES E } \\
\text { CUSTO DAS VENDAS }\end{array}$ & $\begin{array}{l}\text { CICLO DE COMPRAS, } \\
\text { RECEBIMENTO DE } \\
\text { MERCADORIAS, CONTAS A } \\
\text { PAGAR E PAGAMENTOS }\end{array}$ \\
\hline $\begin{array}{l}\text { Auditorias internas da } \\
\text { qualidade }\end{array}$ & $\begin{array}{l}\text { Averiguar se as atividades } \\
\text { de qualidade estão em } \\
\text { conformidade com a forma } \\
\text { planejada e determinar a } \\
\text { eficácia do sistema da } \\
\text { qualidade. }\end{array}$ & $\begin{array}{l}\text { As transações são examinadas } \\
\text { por pessoa independente do seu } \\
\text { preparo (M) }\end{array}$ & $\begin{array}{l}\text { As transações são } \\
\text { examinadas por pessoa } \\
\text { independente do seu } \\
\text { preparo (M) }\end{array}$ & $\begin{array}{l}\text { As transações são examinadas } \\
\text { por pessoa independente do seu } \\
\text { preparo (M) }\end{array}$ \\
\hline Treinamento & $\begin{array}{l}\text { Todo o pessoal que } \\
\text { executa atividades que } \\
\text { influenciam na qualidade } \\
\text { deve ser constantemente } \\
\text { treinado. }\end{array}$ & & & $\begin{array}{l}\text { Os investimentos em treinamento } \\
\text { são confrontados com o } \\
\text { programa e aprovados por } \\
\text { pessoa autorizada (A) }\end{array}$ \\
\hline Assistência técnica & $\begin{array}{l}\text { Manter procedimentos } \\
\text { para assistência técnica } \\
\text { dos produtos. }\end{array}$ & $\begin{array}{l}\text { Os gastos com assistência } \\
\text { técnica são devidamente } \\
\text { provisionados (M) }\end{array}$ & & $\begin{array}{l}\text { Os gastos com assistência } \\
\text { técnica são aprovados por } \\
\text { pessoa autorizada (M) }\end{array}$ \\
\hline Técnicas estatísticas & $\begin{array}{l}\text { Auxiliar no controle do } \\
\text { ciclo da qualidade, na } \\
\text { determinação da } \\
\text { capacidade do processo e } \\
\text { possibilitar a constatação } \\
\text { de tendências. }\end{array}$ & $\begin{array}{l}\text { As estatísticas de vendas são } \\
\text { analisadas pela Administração } \\
\text { (B) }\end{array}$ & $\begin{array}{l}\text { As estatísticas de produção } \\
\text { e custos são analisadas } \\
\text { pela Administração (B) }\end{array}$ & $\begin{array}{l}\text { As estatísticas de compras são } \\
\text { analisadas pela Administração } \\
\text { (B) }\end{array}$ \\
\hline
\end{tabular}




\subsection{O papel do auditor contábil na auditoria de sistemas de garantia da qualidade - Caminhos possíveis}

O papel que vislumbramos para o auditor contábil na auditoria da qualidade não está relacionado ao aspecto da certificação, que envolve entre outras coisas, os organismos especializados em qualidade, um processo formal de habilitação profissional e um mercado concorrencial já estabelecido com poucas empresas que estão estruturadas em nível nacional e internacional.

O papel que propomos com firme conviç̧ão de que o auditor contábil pode e deve dar sua contribuição profissional às questões da qualidade, está relacionado ao valor agregado da auditoria contábil num ambiente empresarial.

Nakagawa $\mathbf{1}$ ao fazer considerações sobre o controle e auditoria interna, afirma que

abordagens que contribuam para a eficácia dos controle internos, bem como da auditoria interna, devem ser recomendadas, especialmente à medida que as empresas se automatizam.

O autor afirma também, que o controle interno em manufaturas otimizadas difere do das manufaturas não-otimizadas, principalmente, pela necessidade de eliminar custos que não adicionam valor.

Drucker $^{2}$ estabelece diferenças entre o significado das palavras controle e controles, afirmando que, sob a ótica administrativa, controle significa direção e controles significa mensurações e informações. Afirma, também, que controles 
são meios para se atingir um fim, que é o controle da organização como um todo, ressaltando, entretanto, que o verdadeiro controle das organizações está nas decisões das pessoas, no elemento humano. Qualquer sistema de controle que não leve em consideração o comportamento do elemento humano (a razão de sua conduta e a causa de sua ação) será na melhor das hipóteses ineficiente.

Estas afirmações se alinham com a visão que apresentamos sobre os controles internos num ambiente empresarial de qualidade. Já discutimos anteriormente que o sistema de gestão e garantia da qualidade é apenas um meio para se conseguir a almejada qualidade total, a qual, inevitavelmente passa pela otimização dos processos.

Se tanto num ambiente empresarial de qualidade como num ambiente de otimização de processos os controles internos são diretamente afetados, há de se refletir não só sobre o papel do auditor contábil na auditoria de sistemas de garantia da qualidade mas, também, sobre o impacto que estas mudanças causarão na forma como hoje os auditores contábeis estudam e avaliam os controle internos, em cumprimento às normas de auditoria geralmente aceitas.

A matriz de correlação entre os requisitos da norma ISO 9001 e o ciclo de controle interno contábil através de alguns pontos de controle, apresentada no item 5.2., sugere ao auditor contábil a irresistível tentação de agregar valor ao seu trabalho mediante a incorporação de procedimentos adicionais de auditoria direcionados ao sistema de garantia da qualidade. 
O ambiente empresarial é entendido como tudo que envolve direta ou indiretamente a gestão empresarial, os negócios, as operações, o meio ambiente, etc.

Carvalho ${ }^{3}$ aborda com bastante clareza a questão do envolvimento do auditor contábil com as operações da entidade objeto de auditoria em seu trabalho sobre o "valor agregado da auditoria financeira" quando, a certa altura, menciona:

Uma auditoria de demonstrações contábeis NÃO se restringe apenas a uma verificação de documentos na contabilidade: ela vai muito além, tendo que verificar se os documentos que chegam à contabilidade para serem registrados e sumarizados nas demonstrações contábeis são fiéis representantes das operações que aconteceram em todas as áreas da entidade, como compras, produção, vendas, tesouraria, recursos humanos, e assim por diante.

Afirma, também, que em decorrência desta necessidade de conhecer as operações das entidades e de obter informações adicionais para formar seu julgamento o auditor contábil se viu obrigado a aumentar sua especialização técnica, passando a dominar áreas como processamento eletrônico de dados, legislação tributária, contabilidade societária, de mercado de capitais e internacional. Adicionalmente, o auditor contábil aumentou seu nível de conhecimento em gestão empresarial, sendo capaz de oferecer sugestões construtivas nas diferentes áreas de uma entidade.

Para se assegurar que a documentação processada pelo sistema contábil seja representativa das operações realizadas pela entidade, o auditor contábil vai buscar nas áreas de origem os subsídios necessários para dar suporte ao seu trabalho e é exatamente na busca destes subsídios que o auditor pode e deve 
desempenhar seu papel agregador/contributivo às auditorias de sistemas de garantia da qualidade.

Este papel pode ser desempenhado em duas fases (dois momentos) distintas do processo de auditoria das demonstrações contábeis. A figura 5.2. abaixo ilustra estes momentos, correlacionando-os com o ciclo administrativo da qualidade.

FIGURA 5.2. - MOMENTOS DE AUDITORIA CONTÁBIL E O CICLO ADMINISTRATIVO DA QUALIDADE.

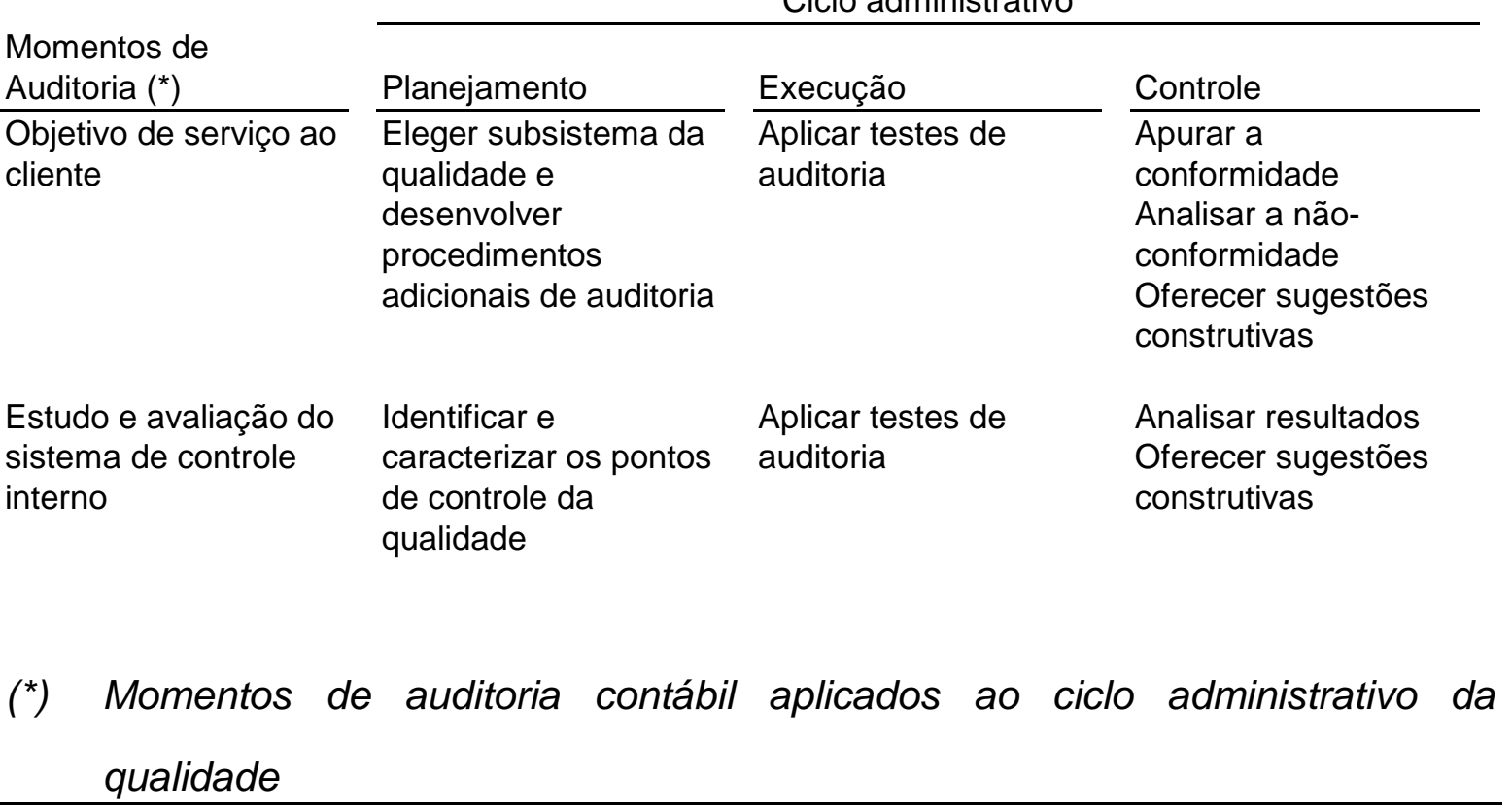

A primeira fase está na definição de objetivos de serviços ao auditado quando o auditor contábil, sempre atento às oportunidades de agregar valor ao seu serviço e ciente de que o sistema de garantia da qualidade é uma prioridade, e por conseguinte uma preocupação do Conselho da Administração e demais pessoas de uma entidade, poderia eleger um subsistema do sistema de gestão e garantia 
da qualidade ou identificar e caracterizar alguns pontos de controle da qualidade e, utilizando seus conhecimentos das técnicas de auditoria, poderia desenvolver procedimentos adicionais de auditoria, que seriam executados durante o curso normal dos seus trabalhos, com o objetivo de identificar, eventuais, nãoconformidades e oferecê-las ao auditado como um subproduto do objetivo principal de seu trabalho, que é expressar uma opinião sobre as demonstrações contábeis.

A falta de um conhecimento mais especializado sobre determinadas áreas seria 0 primeiro empecilho para a execução da auditoria de alguns sub-sistemas do sistema de garantia da qualidade ou validação de alguns pontos de controle da qualidade. Exemplo: o auditor contábil deveria possuir conhecimentos de metrologia para estar em condições de auditar o sub-sistema Equipamento de inspeção, medição e ensaios.

Este tipo de empecilho tem sido comum no dia-a-dia do auditor contábil. Inúmeras são as situações em que estes profissionais têm de se valer do conhecimento especializado de outros profissionais para formar seu juízo sobre determinados assuntos e emitir sua opinião. Exemplo: é comum o auditor contábil recorrer aos serviços profissionais de um engenheiro para formar juízo sobre a razoabilidade de medições de determinadas obras, ou de um ourives para confirmar os quilates de pedras preciosas, ou de um advogado para opinar sobre demandas judiciais e, até mesmo, de outros auditores quando parte da auditoria das demonstrações contábeis são executadas por estes profissionais, etc.

Diante de empecilhos desta natureza, entendemos que a mesma estratégia pode ser utilizada para as questões da qualidade ou seja, se o auditor contábil não 
possuir, por exemplo, os conhecimentos de metrologia imprescindíveis à execução de auditorias do subsistema Equipamentos de inspeção, medição e ensaios e identificar que este subsistema representa uma preocupação para o gestor do sistema de garantia da qualidade, por razões diversas, ele poderá se valer do conhecimento especializado de outros profissionais para que possa cumprir com seu objetivo de serviço ao cliente agregando valor ao seu trabalho.

O segundo momento está no estudo e avaliação do sistema de controle interno. Conforme abordamos anteriormente, o sistema de gestão e garantia da qualidade, uma vez implementado, é parte integrante do sistema de controle interno.

As normas de auditoria geralmente aceitas requerem que o auditor adquira um entendimento sobre a estrutura do sistema de controle interno suficiente para estabelecer um grau de confiança nesse sistema e, a partir daí, determinar a extensão e a oportunidade (cronograma) para realização de outros procedimentos de auditoria.

No momento em que estiver estudando e avaliando o sistema de controle interno de uma entidade que pratica qualidade, o auditor contábil fatalmente se envolverá com questões da qualidade que estarão justificando muito dos controles e procedimentos adotados por aquela entidade, os quais não se encontram em entidades que não praticam qualidade. Exemplos: Quando o auditor contábil for estudar e avaliar os controles internos na área de compras, além dos pontos de controle tradicionais, ele encontrará um ponto de controle sobre a avaliação de fornecedores que geralmente não existe nas entidades que não praticam qualidade. $\mathrm{Na}$ área de vendas, o auditor contábil encontrará o ponto de controle sobre análise crítica dos contratos, isto é, todos os pedidos de vendas recebidos 
pela entidade são analisados para assegurar que seu conteúdo possa ser plenamente atendido. $\mathrm{Na}$ área de recursos humanos, o auditor contábil encontrará um ponto de controle sobre o histórico individualizado dos treinamentos atendidos pelos colaboradores ao longo de sua carreira na entidade.

Os exemplos citados são controlados dentro das respectivas áreas e serão perceptíveis ao auditor contábil quando do estudo e avaliação do sistema de controle interno daquelas áreas. Contudo, existem outros pontos de controle mais evidentes. Exemplo: a existência de um gestor para o programa de qualidade, a existência de controles estatísticos disseminados por toda a entidade, a existência de um mapeamento formal e documentado de todas a atividades, e assim por diante.

As diferenças entre os controles e procedimentos adotados por entidades que praticam qualidade serão perceptíveis já no ambiente de controle, onde a atmosfera que deve contribuir para um controle efetivo deverá ser mais favorável.

A própria filosofia burocratizante (absolutamente tudo que envolve qualidade é manualizado, registrado, documentado e arquivado) do sistema de gestão e garantia da qualidade acaba por contribuir para que todas as pessoas dentro da organização estejam mais atentas aos objetivos estabelecidos para a organização como um todo, e não apenas àqueles voltados para as questões da qualidade.

Este ambiente de alerta contínuo acaba por reduzir os riscos de que os objetivos definidos pelo Conselho e a alta administração, quer sejam eles para as questões da qualidade, quer sejam para a organização como um todo, deixem de ser cumpridos. 
Os sistemas de informações, geralmente, informatizados são modificados para incorporar o sistema de gestão e garantia da qualidade, tornando-se um campo fértil para o auditor contábil explorar uma de suas especialidades, que é o processamento eletrônico de dados.

O processo de comunicação torna-se mais dinâmico, fomentando a tão esperada comunicação de baixo para cima. O nível de participação dos funcionários através dos canais de comunicação gerados pelo sistema de gestão e garantia da qualidade, alguns deles já comentados anteriormente como; café da qualidade, cumbuca, programa de sugestões, melhora e torna-se mais efetivo.

As decisões de mudanças de rota necessárias ao cumprimento dos objetivos estabelecidos tornam-se mais "democráticas", o que acaba por facilitar o processo de monitoramento do sistema de controle interno da entidade.

Estas alterações fundamentais na estrutura organizacional e principalmente no clima das organizações que praticam qualidade são claramente percebidas pelo auditor contábil, que no seu dia-a-dia convive com as empresas que praticam qualidade (minoria) e as empresas que não praticam a qualidade (maioria).

Com base nestas constatações, o auditor contábil passa a conviver com duas realidades empresariais distintas e que, portanto, requerem serviços distintos. As organizações que não praticam qualidade provavelmente estarão satisfeitas com os serviços que seus auditores vêm prestando e não abririam demanda por melhorias a curto prazo. Em contrapartida, as organizações que praticam qualidade mudaram de patamar, atribuíram a si mesmas um grau maior de 
exigência em suas atividades do dia-a-dia e tendem, inevitavelmente, a curto prazo, a estender este nível de exigência a seus parceiros (clientes e fornecedores).

É de se esperar que, num futuro próximo, até mesmo por imposição das normas e procedimentos aplicáveis aos sistemas de garantia da qualidade, o auditor da qualidade passe a avaliar o trabalho do auditor contábil, podendo inclusive vir a reprová-lo, criando uma rota de colisão que o auditor contábil somente poderá evitar se também estiver praticando qualidade no seu cotidiano.

Este é o horizonte que vislumbramos e para o qual o auditor contábil não poderá fechar os olhos. Alguns caminhos possíveis para sua efetiva participação nas auditorias da qualidade foram discutidos neste trabalho, que não teve o objetivo de esgotar o assunto, mas, sim de contribuir de alguma forma não só com os profissionais de auditoria contábil, mas também com todas as partes envolvidas. 


\section{NOTAS}

1 Nakagawa, Masayuki - Gestão Estratégica de Custos: Conceitos. Sistemas e Implementação - São Paulo, Atlas, 1991 - pp. 90 e 91

2 Drucker, Peter Ferdinand - Introdução à Administração - Tradução: Carlos A. Malferrari - São Paulo, Pioneira, 1984.- pp. 503 a 513.

3 Carvalho, Luiz Nelson Guedes - Valor agregado da auditoria financeira; Trabalho apresentado no Congresso Latino-americano de Contabilidade 1993. 


\section{CONCLUSAOO}

Para um profissional da auditoria contábil, a partir do momento em que os auditados, no conceito da qualidade, seus clientes, passam a dedicar parcela cada vez mais expressiva de seu tempo na busca da qualidade, da produtividade, ou seja, na busca da melhoria contínua ou continuada, torna-se quase que obrigatório um esforço adicional no sentido de satisfazer esta emergente necessidade de seus clientes.

É claro que para poder oferecer este tipo de contribuição ao auditado o auditor contábil tem de adquirir conhecimentos especializados sobre os sistemas de gestão e garantia da qualidade, fato que para este profissional não implica novidade.

Conforme discutido no Capítulo 5, conclui-se que uma auditoria de demonstrações contábeis não está restrita a uma mera inspeção documental, dos arquivos mantidos pela contabilidade, indo muito além, pois obriga o auditor a desenvolver um senso crítico apurado que lhe permita verificar se, além de hábeis, os documentos são fiéis representantes das operações realizadas pelas diversas áreas da entidade.

Conclui-se que do envolvimento do auditor contábil com as outras áreas surgiu a necessidade de conhecer as operações das entidades e de obter informações 
adicionais para formar seu julgamento. Com essa visão empresarial, o auditor contábil se viu obrigado a aumentar sua especialização técnica e seu nível de conhecimento em gestão empresarial, sendo capaz de oferecer sugestões construtivas nas diferentes áreas de uma entidade.

$\mathrm{Na}$ esteira destas conclusões é que incluímos o sistema de gestão e garantia da qualidade. Para se assegurar de que a documentação processada pelo sistema contábil é representativa das operações realizadas pela entidade, o auditor contábil vai buscar nas áreas de origem os subsídios necessários para dar suporte ao seu trabalho. As chamadas áreas de origem, como não poderia deixar de ser, são as mesmas que compõem o ciclo da qualidade, abrangendo o negócio como um todo, desde a função marketing e pesquisa de mercado até a disposição após uso.

Seguindo esta linha de raciocínio, podemos afirmar que, com relação aos sistemas de gestão e garantia da qualidade, o auditor contábil está diante de mais um desafio profissional a ser vencido, à medida que a demanda por este tipo de especialização é crescente.

A formação de uma estrutura de apoio incluindo profissionais altamente especializados tem sido a estratégia utilizada pelo auditor contábil para vencer estes desafios e, com relação aos sistemas de gestão e garantia da qualidade, não será diferente. A utilização de equipes de auditoria multi-disciplinares se apresenta como uma alternativa para que o auditor contábil possa desempenhar adequadamente seu papel na auditoria de sistemas de garantia da qualidade. 
Afirma-se isto com base em observações e constatações de que algumas entidades especializadas em auditoria contábil já mantêm em seus quadros profissionais com especialização em sistemas de gestão e garantia da qualidade e já estão oferecendo aos seus auditados e/ou clientes apoio especializado para desenvolvimento, implementação e manutenção destes sistemas.

Conclui-se que a matriz de correlação entre um sistema de garantia da qualidade de acordo com a norma ISO 9.001 e o ciclo de controle interno contábil indica um caminho para o auditor contábil fornecer sua contribuição profissional à auditoria da qualidade. Um outro caminho identificado está diretamente relacionado à definição dos objetivos de serviço ao auditado/cliente quando o auditor contábil pode eleger um subsistema do sistema de gestão de garantia da qualidade ou identificar e caracterizar alguns pontos de controle da qualidade, e aplicar testes de auditoria oferecendo os resultados a título de sugestões construtivas.

Conclui-se que as qualificações necessárias para que o auditor contábil possa desempenhar adequadamente seu papel na auditoria da qualidade precisam ser desenvolvidas. Assim, os programas de treinamento contínuo, mantido pelas empresas especializadas em auditoria de demonstrações contábeis, para formação de auditores contábeis, deverão obrigatoriamente incorporar os conceitos da qualidade, assim como as universidades deverão incorporar em seus currículos noções e conceitos de qualidade para que o profissional de amanhã não venha a tomar contato com as questões da qualidade apenas quando adentrar o mercado de trabalho. Se hoje a experiência profissional em ambientes que praticam qualidade já é um fator que diferencia profissionais no mercado, o que poderá ser dito acerca desse fator no final da década de noventa, com a proximidade do novo milênio? 
Antes de desempenhar qualquer papel em auditorias de sistemas de garantia da qualidade, as empresas especializadas em auditoria contábil devem praticar qualidade internamente, desenvolvendo e implementando seu próprio programa de qualidade. Caso não ocorra por iniciativa destas entidades, a implementação inevitavelmente ocorrerá por pressão ou exigência dos seus clientes que estiverem praticando qualidade, visto que o sistema de garantia da qualidade prevê o engajamento de todos os parceiros no processo.

Como decorrência do processo de globalização da economia e a crescente necessidade de padronização de produtos, serviços e processos, num futuro próximo, para emitir uma opinião melhor fundamentada sobre as demonstrações contábeis de uma entidade, o auditor contábil deverá levar conta as questões da qualidade, ou seja, o sistema de gestão e garantia da qualidade. 
ABNT - Associação Brasileira de Normas Técnicas - NBR ISO 8.402 Gestão da qualidade e garantia da qualidade - Terminologia ${ }_{1}$ Rio de Janeiro, 1993.

. NB ISO 9.000 Normas de gestão da qualidade e garantia da qualidade Diretrizes para seleção e uso. Procedimento - Rio de Janeiro, 1990.

. NB ISO 9.001 Sistemas da qualidade - Modelo para garantia da qualidade em projetos/desenvolvimento, produção, instalação e assistência técnica, Procedimento. - Rio de Janeiro, 1990.

NB ISO 9.002 Sistemas da qualidade - Modelo para garantia da qualidade em produção e instalação. Procedimento, - Rio de Janeiro, 1990.

. NB ISO 9.003 Sistemas da qualidade - Modelo para garantia da qualidade em inspeção e ensaios. Procedimento, - Rio de Janeiro, 1990.

NB ISO 9.004 Gestão da qualidade e elementos do sistema da qualidade Diretrizes. Procedimento: - Rio de Janeiro, 1990.

. NBR ISO 10.011-1 Diretrizes para auditoria de sistemas da qualidade. Parte 1 Auditoria. - Rio de Janeiro, 1993. 
. NBR ISO 10.011-2 Diretrizes para auditoria de sistemas da qualidade. Parte 2 Critérios para qualificação de auditores de sistema da qualidade. - Rio de Janeiro, 1993.

. NBR ISO 10.011-3 Diretrizes para auditoria de sistemas da qualidade. Parte 3 Gestão de programas de auditoria. Rio de Janeiro, 1993.

AMERICAN INSTITUTE OF CERTIFIED PUBLIC ACCOUNTANTS - AICPA Exposição de Normas de Auditoria no 1 Tradução - Equipe da Price Waterhouse Auditores Independentes - São Paulo, Editado pelo Instituto dos Auditores Independentes do Brasil, 1977.

ATTIE, William - Auditoria: Conceitos e Aplicações - 2ª Edição, São Paulo, Editora Atlas S.A., 1984.

BARROS, Claudius D'Artagnan C. de - Qualidade e Participação: o caminho para o êxito - São Paulo, Nobel, 1991.

BÉRGAMO FILHO, Valentino - Os caminhos da qualidade e da produtividade; Como entender os conceitos da qualidade de um modo simples e gostoso, São Paulo, Editora Edgar Blücher Ltda, 1991.

BLUTAUMÜLLER, Kartheinz - Como se preparar para auditoria - Artigo publicado na Revista Controle da Qualidade, Edição no 17, de outubro de 1993.

CAMINADA Netto, Adherbal - Apostila: Auditorias da Qualidade - Curso ministrado na CPC - Companhia Petroquímica de Camaçari - Unidade São Paulo, 1994. 
CAMPOS, Vicente Falconi - Gerência da Qualidade Total, Belo Horizonte - MG, Block Editores S.A. 1989.

- - TQC Controle da Qualidade Total (no estilo japonês), Belo Horizonte MG, Block Editores S.A., 1992.

CARVALHO, Luiz Nelson Guedes - Parecer dos Auditores Independentes sobre Demonstrações Contábeis no Brasil: Estudo das limitações ao seu poder de comunicação ${ }_{1}$ Dissertação de Mestrado FEA - USP, 1989. pp. 24 a 27.

. - Valor Agregado na Auditoria Financeira - Trabalho apresentado no Congresso Latino-Americano de Contabilidade, 1993.

CERQUEIRA, Jorge Pedreira de e MARTINS, Márcia Copllo - Formação de auditores internos da qualidade - São Paulo, Pioneira, 1994.

CROSBY, Philip B. - Quality is free. The Art of Making Quality Certain - New York, McGraw-Hill Book Company.

DALE, Barry G. e PLUNKETT, Jim J. - Managing Quality - London, Philip Allan, 1990.

DELOITTE TOUCHE TOHMATSU Auditores Independentes - Enfoque de Auditoria - Tradução revisada Agosto/91.

- Internal Control - New York, 1993. 
DEMING. William Edwards - Out of the crisis - Massachusetts, Massachusetts Institute of Technology, 13th printing, April 1991.

DRUCKER, Peter Ferdinand - Introdução à Administração - Tradução: Carlos A. Malferrari - São Paulo, Pioneira, 1984.

FRITJOF, Capra - O ponto de mutação - Tradução Álvaro Cabral, Revisão técnica da tradução Newton Roberval Eichemberg, Editora Cultrix, São Paulo, 1982.

FUNDAÇÃO CHRISTIANO OTTONI - Casos reais de implantação de TQC: Gerenciamento da rotina, Program 5S, Garantia da qualidade - Volume 1 e PDCA Métodos de Solução de problemas - Volume 2, São Paulo, 1993.

GIL, Antonio de Loureiro - Qualidade total nas organizações: indicadores de qualidade, gestão econômica da qualidade, sistemas especialistas de qualidade São Paulo; Editora Atlas S.A., 1992.

- Auditoria da Qualidade - São Paulo; Editora Atlas S.A., 1994.

- Auditoria de Computadores - São Paulo; Editora Atlas S.A., 1989.

- Sistemas de Informações Contábeis/Financeiras - São Paulo, Editora Atlas S.A., 1992

IMAI, Masaaki - KAIZEN A estratégia para o sucesso competitivo - 3ª Edição, Tradução de Cecilia Fagnani Lucca, São Paulo, Instituto de Movimentação e Armazenagem de Materiais - IMAM, 1990. 
INTERNATIONAL FEDERATION OF ACCOUNTANTS - IFAC - IFAC Handbook 1992 Technical Pronouncements, New York, 1992.

INTERNATIONAL STANDARD ISO 8402 - Quality -Vocabulary, 1986.

ISHIKAWA, kaoru - Controle de Qualidade Total: à maneira japonesa. - 2ª Edição, Tradução de lliana Torres, Rio de Janeiro, Editora Campus, 1993.

JURAN, Joseph Moses e GRYNA, Frank M. - Controle da qualidade handbook. Conceitos, políticas e filosofia da qualidade. Tradução Maria Cláudia de Oliveira Santos, Revisão técnica TQS Engenharia - São Paulo, Makron, McGraw-Hill, 1991.

- - Controle da qualidade handbook. Componentes básicos da função qualidade. Tradução Maria Cláudia de Oliveira Santos, Revisão técnica TQS Engenharia - São Paulo, Makron, McGraw-Hill, 1991.

JURAN, Joseph Moses - Juran planejando para a qualidade; Tradução de João Mário Csllag e Cláudio Csllag. - São Paulo, Pioneira, 1990.

LOBOS, Júlio - Qualidade através das pessoas, São Paulo, Câmara Brasileira do Livro, 1991.

. - Encantando o cliente: externo e interno, São Paulo; J.Lobos, 1993. 
LUBBEN, Richard T. - Just in time: Uma estratégia avançada de produção - $2^{\underline{a}}$ edição. Tradução: Flávio Diniz Steffen, Revisão técnica: Flarry G. Fockink, São Paulo, McGraw-Hill, 1989.

MANN, Nancy R. - DEMING As chaves da excelência. Tradução José Carlos Brabosa dos Santos; revisão técnica José Carlos de Castro Waeny. - São Paulo, Makro, McGraw-Hill, 1992.

MCG, Qualidade, associada à P-E. Batalas - Apostila: Auditorias da Qualidade Curso ministrado à empresas que praticam qualidade.

NAKAGAWA, Masayuki - Gestão Estratégica de Custos: Conceitos. Sistemas e Implementação - São Paulo, Atlas, 1991.

O'HANLON, Tim - O auditor líder. Uma história sobre auditoria de sistemas de qualidade, Tradução de Mônica F.H. Cavalcanti, São Paulo, Editora Pioneira, 1994.

REBELO, Antonio Raimundo Coutinho - Auditorias da qualidade, Artigo publicado na Revista Controle de Qualidade, № 17, outubro de 1993.

ROBERTS, Harry V. e SERGESKETTER, Bernard F. - A qualidade é pessoal uma base para a gerência de qualidade total. - Tradução Nivaldo Montingelli Jr. - São Paulo, Livraria Pioneira Editora, 1994. 
ROBLES, Antonio Jr. - Custos da Qualidade. Uma estratégia para a competição global.- São Paulo, Editora Atlas S.A., 1994.

SULLIVAN, Lerry D., GNOSPELIUS, Richard A., DEFLIESE, Philip L. and JAENICKE, Henry R. - Montegomery's Auditing - Tenth Edition, A Ronald Press Publication - John Wiley \& Sons, New York, 1985.

THE AMERICAN ACCOUNTING ASSOCIATION (AAA) - A Statement of Basic Auditing Concepts - N.York, 1973.

THE COMMITTEE OF SPONSORING ORGANIZATIONS OF THE TREADWAY COMMISSION - Internal control: Integrated framework - Exposure Draft March 12, 1991; New York, 1991.

THE INSTITUTE OF CHARTERED ACCOUNTANTS IN ENGLAND AND WALES

- Auditing and Reporting 1993/94, the full texts of all UK auditing standards and guidelines, all UK auditing exposure drafts other statements on auditing extant at April 1993 - London, 1993.

YOSHINAGA, Ciro - Qualidade Total A forma mais prática e econômica de implementação e condução, São Paulo, 1988. 